Portland State University

PDXScholar

8-1981

\title{
Trouble in River City: An Analysis of an Urban Vice Probe
}

Joseph S. Uris

Portland State University

Follow this and additional works at: https://pdxscholar.library.pdx.edu/open_access_etds

Part of the Public Affairs Commons, Public Policy Commons, and the Urban Studies Commons Let us know how access to this document benefits you.

\section{Recommended Citation}

Uris, Joseph S., "Trouble in River City: An Analysis of an Urban Vice Probe" (1981). Dissertations and Theses. Paper 4493.

https://doi.org/10.15760/etd.6377

This Dissertation is brought to you for free and open access. It has been accepted for inclusion in Dissertations and Theses by an authorized administrator of PDXScholar. Please contact us if we can make this document more accessible: pdxscholar@pdx.edu. 
TROUBLE IN RIVER CITY: AN ANALYSIS OF

AN URBAN VICE PROBE

by

JOSEPH SAMUEL URIS

A dissertation submitted in partial fulfillment of the requirements for the degree of

DOCTOR OF PHILOSOPHY

in

URBAN STUDIES

Portland State University

C) 1981 Joseph Samuel Uris 
TO THE OFFICE OF GRADUATE STUDIES AND RESEARCH:

The members of the Committee approve the dissertation of Joseph Samuel Uris presented August 7, 1981.

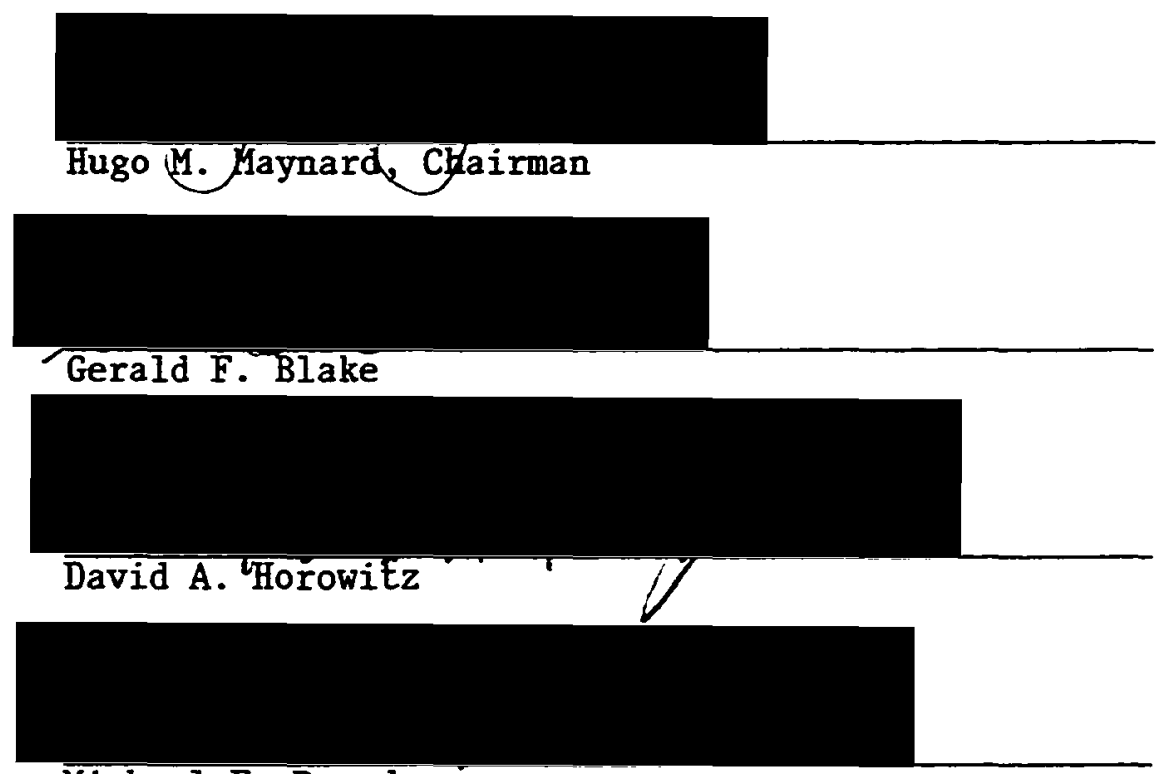

Michael F. Reardon

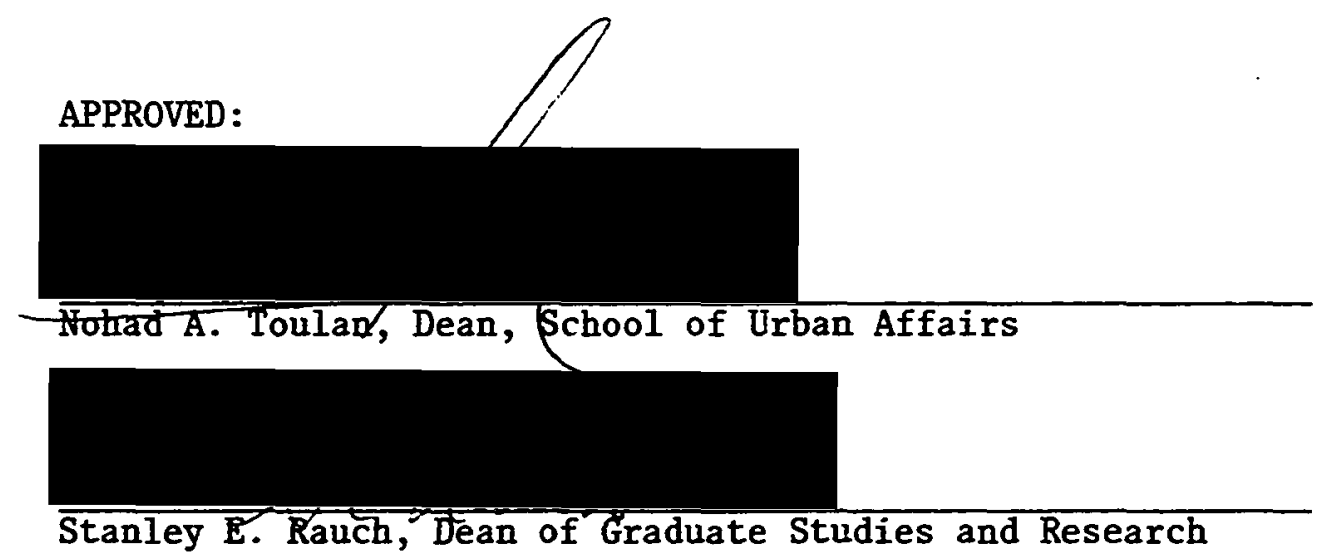


AN ABSTRACT OF THE DISSERTATION OF Joseph Samuel Uris for the Doctor of Philosophy in Urban Studies presented August 7, 1981.

Title: Trouble in River City: An Analysis of an Urban Vice Probe. APPROVED BY MEMBERS OF THE DISSERTATION COMMITTEE:

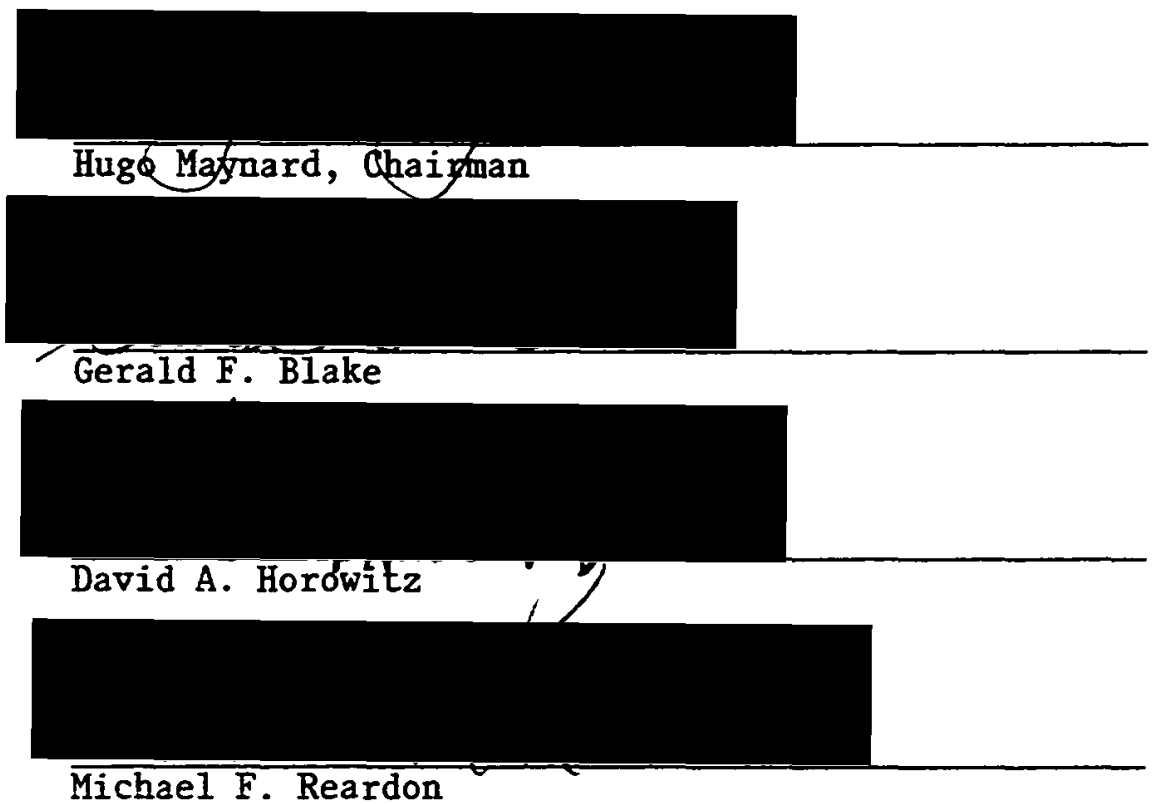

\section{ABSTRACT}

This dissertation is an historical case study of a highly publicized investigation of vice and official corruption which took place in Portland, Oregon from 1954 to 1958. Three major relevant areas of social science literature are reviewed. These are: historical material on American reform and corruption, criminology and political science. This literature suggests both the ubiquity and usefulness of vice and corruption in the urban situation. 
A set of propositions regarding vice, corruption and reform was developed from these works. These propositions were then examined in terms of the vice probe and political situation in Portland, Oregon.

The triangulation method of this study involves three separate data sources: popular accounts in the print media; government documents, including material from the Oregon State Archives, the City of Portland and the U.S. Senate Select Committee on Improper Activities in the Labor or Management Field; interviews conducted by the author (1979-1981) with persons who had intimate knowledge of the vice situation, political arrangements or corruption in Portland.

This case study has utility and general application beyond the single case illustrated. It demonstrates the functions and limits of corruption and reform. While historical in nature, this study offers insight into processes seen in many cities today. 


\section{ACKNOWLEDGEMENTS}

This project could not have been accomplished without the help of people from many walks of life. First and foremost, I thank the men and women, famous and anonymous, who shared their unique knowledge of these events. Without their interviews this dissertation would be like a twolegged stool.

Thanks go to the two principal typists: Melinda Burch, who typed the working drafts and interview transcriptions; and Karen Davidson who typed and edited the final product. Thanks also to Joyce büles, Pat Gold and Catherine Paglin.

I gratefully acknowledge the many hours of aid and ajvice given by J.D. Porter, the Oregon State Archivist. Luella Pollock, librarian at Reed College was most generous with materials in Reed's excellent collection of U.S. Government documents. The Oregonian generously made its Oregon Journal and Oregonian files available. The Multnomah County Library proved a wonderful resource.

I am indebted to my dissertation committee members, Gerald Blake, David Horowitz, Michael Reardon and my Chairman, Hugo Maynard.

A Law Enforcement Assistance Administration, National Criminal Justice Education Development Project Fellowship made the initial research for this dissertation possible. For this I would like to thank Don Gibbons, the Project Director.

Finally, I dedicate this work to Charlotte Asendorf, whose patience, support, criticism and inspiration made it happen. 
TABLE OF CONTENTS

PAGE

ACKNOWLEDGEMENTS . . . . . . . . . . . . . iii

LIST 0 T TABLES .................. . . vi

CHAPTER

I INTRODUCTION

The Historical Incident . . . . . . . . 4

The Case History. . . . . . . . . . 5

II THEORETICAL FRAMEWORK. . . . . . . . . . 7

The Traditional Functionalist View. . . . . . 8

Marxism and Crime - Left-Handed Functionalism . . 10

The Machines and the Reformers. . . . . . . 16

Organized Crime and Corruption: Four Modern

Cases.............. 23

The Media and Modern Reform . . . . . . . 34

Outsiders and Reform. . . . . . . . 36

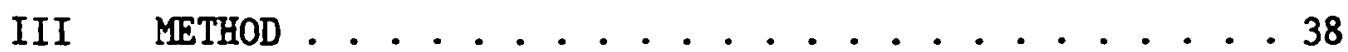

Triangulation of Sources. ....... 38

The Data Sources. . . . . . . . . . 39

Interview Technique . . . . . . . . 44

Method Sumnary. . . . . . . . . . 50

IV HISTORY OF THE VICE PROBE. . . . . . . . . 52

Overview of the Portland Vice Probe of 1956-1958. 53 
The Second World War and After, 1940-1948 ... 55

The 1948 Reform Movement. . . . . . . . . 59

Vice Sirvives . . . . . . . . . . 66

The Exposition-Recreation Center Deal -

1954-1956. . . . . . . . . . 71

James Elkins - The Man Who Talked . . . . . 75

Two Papers, Two Views .... . . . . . . 76

The Teamsters Move In . . . . . . . . 79

A View From a Distance - The State Capito1. . . 86

The View From the Grand Jury. . . . . . . . . 94

The U.S. Senate Select Committee on Improper Activities in the Labor or Management Field Takes on Portland. . . . . . . . 95

The Journal's View. . . . . . . . . . . . 171

The Schrunk Position and the Portland Network . .201

V ANALYSIS OF THE PORTLAND VICE PROBE. . . . . . . . 209

What Really Happened? . . . . . . . . . .209

The Propositions and the Case History . . . . . 216

VI CONCLUSION . . . . . . . . . . . . . . . . 234

BIBLOGRAPHY. . . . . . . . . . . . . . . . . . . . . . . . . . . 


\section{LIST OF TABLES}

TABLE

PAGE

I Interview Respondents by Category. . . . . . . . 46 


\section{CHAPTER I}

\section{INTRODUCTION}

Perhaps no more common image of urban American crime exists than that of the gangster or racketeer who, with cunning and ruthlessness, moves against law and order to establish a violent empire. There are few who have escaped the vision of The Godfather or Public Enemy Number One. In the popular press as well as on the screen, the crime lord is depicted as an aberrant type; a rare, bad breed who, together with the corrupt cop, preys upon the innocence of the law-abiding citizen.

Yet the phenomenon of the vice lord, the bribed policeman and the corrupt pcritician survive to reappear in countless cities, many times throughout history. American urban corruption, vice and crime, with their networks of cooperating crooks and political bagmen, is well documented by scholars as well as yellow journalists.

The ubiquitous phenomena of vice and its inevitable sister, corruption, have not escaped the attention of modern social science. Indeed, disciplines far apart in perspective have found surprising common ground on the issue. Functional sociologists Robert K. Merton (1949) and Kingsley Davis (1971) focus largely upon how the urban system maintains and perpetuates itself. Marxist sociologists Stephen Spitzer (1975) and Paul 0. Hirst (1972) argue that systemic contradictions between classes will bring about inevitable and fundamental social change. Yet both schools of analysis support the overriding notion that organized crime, vice, political corruption and machine politics serve the existing order 
in a numier of significant ways. In the main, historians of urban machine politics, corruption and reform like Hays (1964), Wade (1968) and Lubove (1969) share this assessment. All three groups see the problem not as an individualistic phenomenon, but rather as a part of the structural context of power and class relations in the urban situation.

Four modern cases of urban machines, vice and corruption will be examined in the following pages: Daniel Bell's (1960) study of organized crime, The End of Ideology; Francis and Elizabeth Ianni's (1972) study of an Italian-American crime family, A Family Business; John A. Gardiner's (1970) case study of organized crime in Wincanton, The Policics of Corruption; and William Chambliss' (1978) study of a crime network in Seattle, On The Take. All four studies suggest important structural and functional aspects of the phenomena. All see the phenomena's survival through time in terms of interest groups served by, and/or in opposition to, the crime, vice and corruption networks surveyed. All emphasize that these occurrences are not individualistic aberrations. Instead, they are seen as serving the interests of groups well rooted in the social structure.

Vice and corruption serve the consumer by providing goods and services otherwise not available through legitimate means. They serve the lower strata of society by providing alternate paths to wealth and power. Vice and corruption serve the interests of the corporate and wealthy classes through risk reduction and certainty in what would otherwise be an uncertain, open market. They serve the political elite by securing financial and other support through a network, at once highly structured and informal, of commitments, sanctions and mutual rewards. Vice and corruption serve existing crime networks by giving them access 
to the politically and economically powerful. At the same time they offer a measure of protection to all involved from serious formal sanction.

Finally, the American phenomenon of corruption, vice, crime syndication and macline politics permits the public at large the luxury of condemning the very activities it freely enjoys. Morally speaking all have their cake and eat it too.

Specifically, as will be shown later, vice and corruption revealed themselves not only in political arrangements and the existence and tolerance of vice, but through real estate deals, special favors in exchange for bribes or other help as well as in the awarding of city franchises for such services as street cars and garbage collection.

This dissertation will attempt to move beyond the popular view of vice and corruption to develop an analysis that delineates some of the major factors that are associated with corruption and vice. The study will explore, as well, the phenomena of the exposure of corruption and the response of reform efforts. Using the work of sociologists, historians and political scientists, a set of propositions concerning the problem and reactions to it will be developed. These propositions, drawn from the analyses of others, will be examined for applicability to a specific case: an incident of vice and corruption, media exposure and reaction, in Portland, Oregsi in the mid-nineteen-fifties. The examination of the Portland incident will be presented in a case history.

If the propositions apply to the Portland case, this will lend them support as general principles applying across different cases. If, on the other hand, some are shown not to be true of the Portland case under analysis, then limits to their generalization will be evident. 
The Historical Incident

The Portland story itself is an interesting tale of the collapse of a criminal network. It starts with a desperate $a=\tau$ by an acknowledged leader in Portland's underworld.

In 1956, a local racketeer - a pinball operator, bootlegger and after-hours boozeball impresario - went to reporters at one of the city's two rival daily newspapers and laid out before them a tale of political corruption, labor union pressure and attempted takeover of the local vice scene by outsiders.

His story, supported by clandestine tape recordings, was published by one of the papers, launching a vice probe that eventually gained national attention and became the starting point for a major U.S. Senate investigation of labor racketeering.

The story and responses to it occupied the front pages of both local papers for months. It created a journalistic war, with the morning paper supporting the tale of their informant and the afternoon paper attacking it, and instigated a far-reaching vice probe by government officials .

Before the probe was over, local, county and state politicians, the city and state police departments, leaders of a national union, and a host of underworld characters would be pazaded before the pubiic and the courts in a series of behind-the-scenes relationships, conspiracies, manipulations and overt criminal activities.

The Portland vice probe resulted in massive negative attention being focused on the local crime scene. The district attorney, the mayor, the police chief and other officials were directly accused of criminal wrongdoing, and several grand juries returned more than 100 criminal indictments. The results, however, in terms of altered 
political careers, criminal convictions and general public condemnation, were surprisingly small. The only man convicted of charges directly stemming from the probe was the local racketeer who made the original complaint. The only elected official removed from office was the district attorney. The only important result, in terms of the structure of power relations in Portland, was the blocking of a vice takeover attempt by outsiders .

The Case History

Nearly a quarter of a century later, the Portland vice probe presents an excellent opportunity for an interdisciplinary analysis of an urban historical event. Press coverage of the probe and the events leading up to it was extensive and that record is available. Persons who were intimately involved are still alive. Government documents concerning the probe abound.

In spite of this documentation, there is no clear consensus, no general agreement on what really happened. The conflicting views and facts so common to historical research reveal the interests, pressures and ideologies that shape the social, political and economic climate of the city. Data for the history itself were gathered from three sources: (1) extensive reports in the local press, particularly the oregonian and Oregon Journal; (2) Oregon public records, including the attorney general's files in the State Archives and the six volumes concerned with the Portland probe from the Hearings of the U.S. Senate Committee on Improper Activities in the Labor or Management Field (85th Congress), held in March of 1957; and, (3) interviews by the author done in 1979, 1980 and 1981 with persons who had knowledge of the vice situation and the probe in the mid-fifties. 
Chronologically, the history begins with a bribery scandal in the Oregon Liquor Control Commission (OLCC) in the fall of 1953 and continues through the revelations of James Elkins, a well-known local gambling, prostitution and bootleg operator, whose accusations launched the vice probe. The Portland vice probe climaxed in the Senate Hearings of March, 1957, mentioned above and the trials and exonerations of many of the principals involved. The history of the event will appear in full in Chapter IV.

Following the history, an analysis of the case will be made using propositions developed from theoretical and historical material presented in Chapter II. As discussed earlier, the limits of the historical study and available social science literature renders the testing of the propositions a limited exploratory exercise. The research is intended to contribute to, but not develop, a complete theoretical model of vice, urban corruption, their exposure and reform.

The final chapter sumarizes both the history and tentative conclusions on the relevance of the propositions to this case study. Further areas for research on urban corruption and approaches that may be useful to others in pursing such research will be suggested. 
CHAPTER II

\section{THEORETICAL FRAMEWORK}

As the American city grew, vice and corruption gre: as well. By the turn of the century a strong tradition of journalistic exposure or urban crime had developed. Foremost among these chroniclers of crime were muckrakers like Lincoln Steffens.

Steffens (1904) exposed the interrelations between American corporate profiteers and urban poifitical machines. He saw the ability to buy special favors from the "boss" was a furdamental cause of corruption. Graft and corruption also served the interests of various groups, he reasoned. These special interests included merchants, manufacturers, contractors and bankers. (Steffens 1904).

Steffens aduressed the ubiquitousness of the problems of corruption and vice in this way:

...The corruption which breaks out here and there now and then is not an occasional offense, but a common practice, the effect of it has literally changed the form of our government from one that is representative of the people to an oligarchy representative of special interests (Steffens 1904, p. 24).

Steffens described a situation in which relationships between the business oligarchy and the city government were frequently informal, based on personal contacts made in social situations. At the lowest level, the ward heeler dealt with individual citizens in saloons, offices and homes meeting at least some of their needs by finding jobs, housing or by intercession with the courts. At the top of government industry, where high-level decision-making took place, the arrangements occurred 
in informal smokers, at private clubs, at dinner parties and at dances. (Steffens 1904; Zink 1930)

In the decades that followed the work of the muckrakers, social scientists carried on analyses of the social, political and economic aspects of urban crime, corruption and reform. It is from this body of work in history, sociology and political science that propositions will be drawn to be applied to the case of Portland in the 1950's. The remainder of this chapter will review approaches to understanding urban corruption and reform. Several areas will be examined, in particular:

1) The functionalists in sociology;

2) Modern Marxist theoreticians in sociology;

3) Analysts of political machines and urban reform from history, sociology and political science;

4) Analysts of organized crime and corruption from sociology, history and political science;

5) Students of mass communication media and urban reform from sociology, political science and history.

From this review of the literature, several propositions concerning corruption, vice and reform will be developed. The propositions will be stated as they emerge in the course of the literature review so that their basis will be apparent to the reader.

\section{The Traditional Functionalist View}

Among sociologists, Robert K. Merton (1949) and Kingsley Davis (1971) have done much to identify how corruption and vice serve various elements of the social order. The functionalists saw "unplanned-for usefulness" in disapproved and illegal activities. This, they argued, is what made corruption such a common feature of urbanization. 
As machine politicians and machines are exposed and weakened, new machines, and new leaders appear because they are in demand, or, as Merton (1949) stated, what will develop is

...an alternative unofficial structure to fulfill existing needs somewhat more effectively ( $p$. 73).

Merton suggested two groups served by political machines; the lower classes and larger businesses.

Business corporations among which the public utilities, railroads, local transportation companies, communication corporations, electric light and power companies and so on, are simply the most conspicuous in this regard, seek special political dispensations which will enable them to stabilize their situation and to near their objective of maximizing profits. Interestingly enough, corporations often want to avoid a chaos of uncontrolled competition. They want the greater security of an economic czar who controls, regulates and organizes the competition, providing the czar is not a public official with his decisions subject to public scrutiny and public control. The latter, of course, would be government control and taboo, and the political boss fulfills these requirements admirably (Merton 1949, p. 75).

Merton went on to point out how much better suited to the service of these groups is the "boss" than the regular inefficient city bureaucracy.

A well-known functionalist analysis of vice is Kingsley Davis' (1971) examination of prostitution. According to Davis prostitution is seen as evil largely because it does not serve the generally dominant social goals. Prostitution divorces the act of sexual intercourse from romantic love, part of the ideological base of our social system. It allows men to engage in sexual activity without the socially controlling liabilities that are normative. At the same time, it can harm the health of individuals in society.

Despite these negative aspects, Davis (1971) pointed out that prostitution serves certain specific functions. It protects the sanctity of the family; giving definition to these women who are not 
respectable as opposed to those women who are, indicating who is and who is not fair game for the aggressive, roving male and allowing casual sex in a situation that does not threaten the stability of the home.

The argument has often been made by vice merchants that prostitution provides an outlet which, if not provided in some appropriate manner, would eventually lead to increased sexual violence (Davis 1971).

From the previous discussion the view that corruption meets certain system needs is evident.

I. URBAN VICE AND CORRUPTION SERVE TO MAINTAIN SYSTEMIC NEEDS.

Marxism and Crime - Left-Handed Functionalism

The Marxist view of the role of srime and criminals in the social structure was well expressed by Paul Hirst (1972). He pointed out that Marx rejected the idea that a criminal class was an inevitable force for social change. In citing the example of bootlegging, Hirst pointed out:

Illegal forms of capitalist production, for example the production and sale of intoxicating liquors in the U.S.A. between 1920 and 1933, have certain specific differences from legitimate, capitalist enterprises. The capital of the illegal enterprises has no legal title as property. Capital that is not legal property is a contradiction that sets very definite limits to its function as capital and which restricts the economic freedom of the illegal enterfrise. The accumulation of capital in such enterprises is limited by their necessarily clandestine character, and this restriction enforces the conversion of such accumulated capital into strictly legal enterprises and the employment of various subterfuges to convert it into legal property (Hirst 1972, p. 53).

Thus, the activity of illegal or illicit businessmen eventually leads them into the area of licit activity. It is ironic, then, that one of the major accusations made against organized crime figures is that they move into the area of legitimate business, as if this particular move were in some manner a nefarious plot to dominate the economy. It 
seems more obvious that such activities are simply a reflection of the need to find appropriate investments for earned capital, to seek legitimate ways to use capital for the benefit of its owners just as does any other businessman.

In Marxist analysis, there is an important point that should be made regarding criminals generally. They rank, as Hirst (1972) suggested, as the lowest levels of what he calls "the industrial reserve army and the lumpenproletariat" (Hirst 1972, p. 52). The lumpenproletariat occupies the lowest economic strata in the city.

The dangerous class, the social scum, that passively rotting mass thrown off by the lowest of old society, may, here and there, be swept into the movement (the movement toward revolution) by a proletarian revolution, its sick (the lumpenproletariat) conditions of life, however, prepared far more for the part of a bribed tool of reactionary intrigue (Marx and Engels 1844, 1968, p. 44).

The lumpenproletariat is, in short, a great body of potential agents for the first and highest bidder for their services. They were Brown Shirts in Nazi Germany, and they can be found today in our American cities, willing to serve whoever is willing to pay them.

Stephen Spitzer (1975), in his article "Toward a Marxian Theory of Deviance and Control," attempted to develop an integrated system of Marxian theory of deviance and control. Spitzer began his theoretical concern by pointing out that the causes of deviance, the sources of deviance in our society, are endemic within the American political economy. He pointed out that many theories of deviance

...affirm the preconceptions and assumptions of the dominant class. Deviance is assumed to reside in the immoral acts of individuals whose behavior we have learned to view as curious, dangerous or bizarre. The moral system framing the evaluation of these acts and its relationship to the interests of the ruling class remains exempt from review" (Spitzer 1975, p. 3). 
Spitzer (1975) asserted that conventional theorists use control as a normal response to deviant activity (Parsons 1949), and that such analyses fail to understand the role cf the state as the device which creates and maintains, as well as defines, a deviant class.

The generally accepted theories of deviance make the state appear as a neutral apparatus, a judgmental body rather than an initiative body in the process of serving the interest of the ruling class.

Evolving his deviance theory in terms of Marxism, Spitzer (1975) proposed:

An understanding of deviance production within capitalist societies requires the investigation of five interrelated elements: (1) the capitalist mode of production; (2) the system of class control in capitalist societies; (3) the character of problem populations in capitalist societies; (4) channeling of problem populations into deviant statutes; and (5) the character of deviant populations (p 16).

Spitzer (1975) saw capitalism, in Marxist terms, as a mode of production which forms the foundation for the basic interests structure of our social system. Further, Spitzer suggested, as do traditional Marxists, that capitalism contains inherently, as do all systems of economic order, the contradictions which will lead to its own transformation.

Spitzer identified what he calls "problem populations," that is, populations that represent the raw material "for production of deviance in capitalist societies." These groups threaten the social relations "of production in capitalist societies." These populations may challenge any of the following:

1) Capitalist modes of appropriating the product of human labor (e.g., when the poor "steal" from the rich);

2) The social conditions under which capitalist production takes place (e.g., those who refuse or are unable to perform wage-labor); 
3) Patterns of distribution and consumption in capitalist society (e.g., those who use drugs for escape rather than sociability);

4) the process of socialization for productive and nonproductive roles (e.g., proponents of alternative societies) (Spitzer 1975, p. 20).

According to Spitzer (1975), while some of these populations may possess revolutionary potential, that potential is significant only if they are indispensable to the system. Furthermore, capitalist societies can easily transform those who are a problem and are indispensable - the proto-revolutionary class - into groups who are problematic and dispensable. Spitzer termed these: candidates for deviance processing. He suggested that such problem populations are created either directly through expressions of contradictions in the capitalist mode of production or indirectly through disturbances in the system of class rule.

As the state expands it locates, labels and deals with more problem populations. To Spitzer, state expansion is only one side of the equation. He lists six other factors influencing labeling and processing rates for problem populations (1975, p. 26):

1) The size and active resistance of the problem population;

2) How well organized the problem population is;

3) How effective civil society's control structures (like the family, schools and the media) are in controlling problem populations;

4) The availability and effectiveness of other forms of state people-processing (like conscription);

5) The usefulness of the problem population for supporting existing social systems; 
6) The effectiveness of parallel control networks like private police and vigilante groups.

In a similar vein, he points out:

The state is often benefited by the policies and practices of organized crime, insofar as these activities help pacify, contain and enforce order among potentially disruptive groups. If criminal enterprises can reliably supply goods and services to problem populations without endangering the hegemony of the ruling class, these enterprises will be sustained. It is only when "criminal conspiracies" and other ogranizations become incompatible with the goals of the state and threaten to undermine its legitimacy that these arrangements themselves become the object of official concern (Spitzer 1975, p. 27).

Spitzer's (1975) final variable also has relevance to this study.

He terms this the "utility of problem populations." While these populations may be a threat co capitalist relations, Spitzer saw problem populations as residual, unprocessed in terms of their deviance. He said:

Residual groups are distinguished by the fact that while they remain generally problematic, the costs that they inflict are most immediately absorbed by other members of the problem population. Policies evolve, not so much to eliminate or actively suppress these groups, but to deflect their threat away from targets which are sacred to the capitalist class. Victimization is permitted and even encouraged, as long as the victims are members of an expendable class. In consequence, the rate of deviance processing is modulated and the maintenance of the capitalist order is insured (p. 28).

Spitzer (1975) further distinguished deviant populations into two basic categories: (1) social junk, who, from the point of view of the dominant of society, are costly but relatively harmless - the mother on welfare, the alcoholic, and so on - who are persons of public concern, but are relatively passive and even useful in the ideological sense, and (2) far more significant, those of the social dynamite class - those who have the potential and the ability to call into question and actively challenge the social system and to actually disrupt the established order and relationships of the social system. 
Spitzer goes on to categorize and explain four methods by which the state deals with dangerous social populations: normalization, conversion, containment and pacification.

The fourth method is one that relates closely to that used by officials in this case study. Under this method, pacification, the state will support criminal enterprise, essentially allowing greater influence and power to organized crime in order to control "dangerous" elements.

Describing this approach, Spitzer (1975) says:

Although predatory criminal enterprise is assumed to stand in opposition to the goals of the state and the capitalist class, it performs valuable and unique functions in the service of class rule. By creating a parallel opportunity structure, organized crime provides a means of support for groups who might otherwise become a burden on the state. The activities of organized crime are also important in the pacification of problem populations. Organized crime provides goods and services which ease the burden and deflect the energies of the underclass. In this role the "crime industry" performs a cooling-out function and offers a control resource which might otherwise not exist. Moreover, insofar as criminal enterprise attempts to reduce uncertainty and risk in its operations, it aids the state in the maintenance of public order. This is particularly true to the extent that the rationalization of criminal activity reduces the collateral costs (i.e., violence) associated with predatory crime ( $p .38$ ).

From the proceeding it can be concluded that:

II. ORGANIZED CRIME IS TOLERATED AS A USEFUL DEVICE FOR PACIFICATION OF POTENTIALLY REBELLIOUS POPULATIONS.

In examining the historical material presented in this dissertation, it can be seen that criminal classes interface with political organizations to form powerful blocs that can carry out policy at the urban level. These groups serve specific functions, and, given only a limited percentage of graft-taking and of illegal activity, they are frequently tolerated and frequently are useful in helping govern. 
However, Spitzer (1975) suggested when such groups effectively organize to threaten the legitimacy of the state, they become serious concern for the state. It is under such circunstances that vice and corruption come under attack. This may be expressed:

III. WHEN CRIMINAL CONSPIRACIES ARE PERCEIVED AS A THREAT TO THE STATE'S LEGITIMACY, THEY THEN BECOME THE OBJECT OF OFFICIAL ACTION.

The Machines and the Reformers

Eric McKitrick (1957) pointed out that machine politics change little through time and that

...the values of mobility, status and respectability operate in the underworld in a way precisely analogous to the workings in the upper (business) world...the extent to which the two worlds overlap in shared values is considerable (McKitrick 1957, p. 507).

Joe Tarr (1967) asserted that the politicians who were involved in urban politics during the reform era were upwardly mobile lower class individuals from humble and/or immigrant backgrounds. For these people

politics provided an alternative form of social and economic mobility to those who found other channels blocked because of the lack of native family roots, wealth or education (Tarr 1967, p. 58).

This echoes the position of Merton (1949) on the functions of the political machine as offering an upward path of mobility to those whose access to upward mobility was blocked by their social position.

The machine politicians were commonly involved in the practice of boodling, in which a politician sells his vote to the highest bidder in such matters as franchise distribution. Votes were sold in Chicago, for example, for promises not to enact legislation in exchange for support from legal and illegal business communities. Funds were frequently deposited in banks that made loans to certain politicians or businesses 
in which politicians held stock. Tax assessments could be raised or lowered, depending on the generosity of persons or corporations being taxed. Boodling also involved the pocketing of large loans, or interest from loans, made by the wealthy to the city (Tarr 1967).

Tarr (1967) emphasized the connections between banking interests, large utility corporations, and other businesses in their relationship to city goveraments. Political alliances really depended upon the mutual satisfaction of both political and economic needs for these groups.

Wade (1968) pointed out that the membership of reform movement was drawn from the new elites, middle and upper classes who had finally gained access to the suburban lifestyle. They were deeply troubled by what they perceived as the old-fashioned style of the city machine. As a rising class, they took advantage of the changes in transportation and communication and moved to the outskirts of town. The new elites championed reform and were major representatives in reform associations. The old machines, on the other hand, respected and shared the interests of the newly arrived immigrant. There was racism and white Anglo-Saxon Protestant bias in reformist movements (Wade 1968).

The new reform movements were famous for their "Committees of $100 "$ or the "Comnittee of 75." Such groups not only had an interest in keeping their neighborhoods safe from crime, vice and corruption, but wanted control of the city as well.

The clash of the new suburbanites and the machines was not one between economic interests as such. Rather, the attack was on the political machine and city hall itself. The basic issue which divided the suburbanites and the machine men was the question of charter reform the attempt to alter the existing structures of governments in the 
cities. Though the cleavage between the two might have beer uch deeper, the issue was whether the oldest residents or the newcomers would shape life in the metropolis. Established residents who dominated city hall in the past, felt themselves losing power and were threatened by the influx to the inner city of ethnic minorities. Inner city populations did not share the motives of suburban reformers. The machine strengthened as reaction within the city centers to the suburban progressive's attempts at reform reinforced the bosses' power (Wade 1968).

In New York, governor Alfred E. Smith united these two major power groups. By the $1920^{\prime} \mathrm{s}$, Smith had built an organization that involved suburban voters, the middle classes and the ethnic minorities of the city center. The heir of Smith's legacy was Franklin Delano Roosevelt. What Smith did on a statewide effort in New York, Roosevelt managed to accomplish nationwide in assembling his constituency for the elections of 1932,1936 and 1940 (Wade 1968).

Analyzing the development of reform in Cincinnati under the Cox machine, Miller (1968) documented parallel changes in three dimensions: geographic change in the loci of population density and class; a shift in party alliance; and, publication of attacks on the Cox machine in the press.

The movement for reform in municipal government constituted an attempt by upper class, advanced professional and large business groups to take "formal political power from the previously dominant lower and middle class elements so that they might advance their own conceptions of desirable public policy" (Hays 1964, p. 165).

Reformers attacked the machine as the most visible institutional element of the ward system, but they were also attacking the entire ward 
form of political organization and the political power of middle and lower class groups which lay behind it. Thus:

IV. REFORM MOVEMENTS FREQUENTLY ACCOMPANY THE RISE OF NEW ELITES IN THE CITY. THEY ARE PART OF A IARGER STRUGGLE FOR CONTROL INVOLVING MAJOR POWER SHIFTS.

Reformers, Hays insisted, wished not simply to replace bad men with good, but they proposed to change the occupational and class origins of decision-makers (Hays 1964).

Robert Dahl (1961) and Nelson Polsby (1960) perceived the urban polity as dominated by sets of contending interest groups. It is competition among these, they argued, that creates change and democracy in the city.

Robert Aggar, Daniel Goldrich and Bert Swanson (1964) saw urban political power as tending to centralize in the hands of elites through a consensual process involving shared goals and beliefs. G. William Domhoff (1978), in attacking Dahl's (1961) view of governance, asserted that elites based on class, status and power dominate city political decision-making. Only in the process of a struggle among these elites for power is there serious conflict. This struggle, historically, as Hays (1964) suggested, can take the outward form of a reform movement.

Weinstein (1968) found that businessmen in the Progressive Era supported and urged reform in the structure of city government. These groups supported both the city commission and city manager forms of government. They opposed the ward form in which councilmen or aldermen were elected from individual wards often representing a specific ethnic class, cultural group or political ideology. 
The city commission plan (as used in Portland) evolved directly in response to the great tidal wave that destroyed Galveston, Texas in 1900 (Weinstein 1968).

Under the Galveston plan a five-man commission, including the mayor, was given the power of the mayor and the old board of aldermen. Each commissioner headed a city department, and each functioned in part as a legislator as well as an administrator. The commission idea was seen as making possible quick, prompt, businesslike and efficient government. Broad powers were given to each commissioner. The idea was that the position would be so desirable that good men would be attracted to the office. The comnission form spread rapidly, first through Texas and then to the north, and by 1913 more than 300 cities from coast to coast had adopted what was then known as the Des Moines Plan, basically the commission charter system (Weinstein 1968).

The results, however, were far from the ideal. Popular but incompetent administrators were frequently selected. Often, these men were more skilled at playing political games than they were at administration. Individual commissioners often found themselves competing with other commissioners for scarce city monies. This meant trade-off's and bargains were necessitated. Since city jobs were in the hands of the commissioners, those officials became very powerful. City commissions fixed both policy and appropriations. Favor-trading and squabbles over 5 separate entities ir constart competition were frequent.

H.S. Gilbertson developed the commission-manager plan as another solution. The commissiorimanager plan was first proposed in Lockport, New York. The Lockport Proposal separated the legislative and executive 
functions by retaining an elected commission to legislate in the city, and providing a paid, appointed manager to assume all executive functions. Executive ability was no longer a prerequisite for successful city commissioners. The day-to-day management of city affairs was removed from political pressure and placed in the hands of a professional manager. The city manager plan became known as the Dayton Plan. Adopted in Dayton in 1913, by 1920 there were more than 103 cities that had adopted the manager plan (Weinstein 1968).

The city manager movement, like the commission movement, was supported by boards of trade and by chambers of commerce. These interest groups felt that electing only a few men on a citywide vote:

...made election of minority or labor candidates more difficult and less likely. Before the widespread adoption of commission and manager government, it was common for workmen to enter politics and serve as aldermen or even mayor. Socialists elected teamsters, machinists, cigar makers, railroad conductors and trainmen, tinners, carpenters, miners and other workers as mayors of dozens of cities and towns in these years. Once the commission plan was in effect, this became rare (Weinstein 1968, p. 139).

The commission and/or manager plan used a non-partisan ballot which was widely supported as a great advance in democracy. However, it tended to operate against political or ethnic minority groups (Weinstein 1968). In effect, it limited the potential for legitimate power of these groups, forcing them to seek alternate and frequently illegitimate paths to power and mobility.

The manager movement spurted ahead in the period just after the Progressive Era. In the five years from 1918 to 1923, nearly a thousand cities adopted manager charters as compared to 97 in the five years before 1918, and 84 in the five years after 1923. 
During the first World War, chambers of comerce and boards of trade greatly intensified their anti-radical and anti-labor activities and in hundreds of small cities and towns Socialist locals were destroyed by the super-patriotic business groups. Just as the war would serve to institutionalize corporation control of regulatory agencies on a national level, so on a local level the business organizations were able to rapidly press forward their political domination of American municipalities (Weinstein 1968, p. 143).

With the newer forms of city government came a closer connection between real estate development and city government. The establishment of promotional commissions such as port commissions became common. By the late 1960 's this combination of public agencies and private interests had evolved in form and impact. Its culmination came in frequent urban renewal projects. Corporate needs were served by public investment to raise the tax base and alter land use patterns (Lubove 1969).

Urban renewal movements, with their inevitable displacement of ethnic minorities and destruction of their communities, then, are part of a process in which state involvement in support of the business community emerges as a late development in the reform movement (Lubove 1969).

The coming together of the city government and the private developer in land use gradually introduced an opportunity for graft and for investment of monies gained through vice activities (Stephens 1904, Hays 1964, Tarr 1967). There was a strong reaction both to urban renewal projects themselves and to questionable practices associated with those projects. This became, as Calvert (1972) suggested, a...

...conflict in the American urban polity between two mentalities, a real estate mentality and a taxpayer mentality. The real estate mentality belongs to developers, speculators and business interests desiring expansion and growth, and the taxpayer mentality characterizes homeowners, non-expansive "lumpen bourgeouisie" business interests (Calvert 1972, p.55). 
The distribution and development of land through the involvement of city government offer an opportunity for corruption to emerge. As this process grows, it deepens the possibility for abuse. Thus:

V. URBAN STRUCTURAL REFORMS IN SUCH AREAS AS LAND USE PLANNING SERVE THE ECONOMIC INTERESTS OF POWERFUL EIEMENTS IN THE CITY AND AT THE SAME TIME PROVIDE NEW OPPORTUNITIES FOR CORRUPTION.

\section{Organized Crime and Corruption: Four Modern Cases}

Four cases of organized crime illustrate the interaction of vice and political power in the contemporary urban situation. Two of these (Bell 1960, and Ianni and Ianni 1972) deal with Italian-American crime syndicates. Both operated in an interstate network and both have been characterized as part of the Mafia. Bell's (1960) model dealt with the rise of the well-known gambler and bootlegger, Frank Costello, who gained political influence and legitimacy in the process of bankrolling political machines. Ianni and Ianni (1972) emphasized the unique kinship model used by the more traditional Sicilian-style crime family. They detailed the evolution of the crime family from local to national and from illegal to legal business activity.

In the third case Gardiner (1970) studied a Jewish-based crime syndicate that functioned as part of a local politically influential group with ties of economic convenience to larger crime networks on a regional scale. In the fourth case, Chambliss (1978) presents a model of local crime networks that is not a unique phenomenon of ethnic or individual significance, but a form of deviance structured into the pattern of economic and political life of the city. He emphasized its permanence even as its leading figures change. 
Daniel Bell (1960) found that vice and political corruption coexist in a society which has made enormous efforts to curb human appetite:

From the start, America was at one and the same time a frontier community where everything goes and the fair country of the blue laws (Bell 1960, p. 116).

Davis (1971) made essentially the same point in dealing with the pervasiveness of prostitution. The outlawing of popular pleasures may result less in the reduction of the undesirable activities than in the creation of new groups of offenders.

As Bell (1960) emphasized, the outlawing of liquor did not stop the abuse of alcohol. Instead, large groups of offenders and a new illegal industry designed to serve them was created. Laws that fail to reflect the generally shared norms become a part of the opportunity structure that leads not only to liw violation but to corruption as well. This suggests that:

VI. OPPORTUNITIES FOR VICE AND CORRUPTION CAN EXIST DUE TO THE CONTRADICTION BETWEEN IDEALIZED NORMS AND ACTUAL BEHAVIOR AS REFLECTED IN CRIMINAL LAW.

Bell saw a shift in big business contributions to political campaigns from local contests to national affairs. This shift left a void in funding which was solved in three ways:

1) Monies from city employees in the form of contributions from city employee unions and/or time spent campaigning for elected officials;

2) The taxing of gamblers through the selling of such devices as the bookmaking licenses of Jersey City. License fees were often by percentage; 
3) Funding from newly gained, often illegally earned, wealth as in the case of Frank Costello (Bell 1960).

Frank Costello's Interstate Network. Frank Costello's career, his development from bootlegger to patron of politicians, is used by Bell (1960) to demonstrate the rise of the illegally wealthy in politically influential circles.

Costello faced a crisis with the repeal of the Volstead Act. His big break came when Huey Long, who needed ready cash to fight the oldline political machine in Louisiana, offered Costello the opportunity to install slot machines in that state. Costello did so and flourished. Together with Dandy Phil Kastel, he opened the Beverly Club, an elegant gambling establishment, in New Orleans (Bel1 1960).

Costello went on to invest in New York real estate, in the Copacabana Night $\mathrm{Club}$, and in a leading brand of Scotch whiskey. His opportunities to gain power in New York came when Tammany, starved for lack of patronage from Franklin Roosevelt and Fiorelo La Guardia, turned to him for financial support. Costello exploited Italian-American grievances against the Irish and, to a lesser extent, against Jewish political groups (Bell 1960).

The Mafia Model. Popularity of the Mafia crime theme is well known. The Appalachian meeting in 1958 of wealthy Italian-American underworld figures for a barbeque at the home of Joseph Barbara is cited often as an example of a gathering of Italian Mafia families. Twenty of those at the meeting were found guilty of obstructing justice because the federal government said they were lying about the purpose of the meeting. A 1960 appellate court decision overturned the conviction because the government had failed to demonstrate that any improper conduct took place 
at the meeting (Gibbons 1977). The evidence of Valachi, the findings of Senator Estes Kefauver (1951), support the view that a single powerful crime network exists in the United States today. The President's Commission on Law Enforcement and Administration of Justice (1967) and the Task Force on Organized Crime (1976) agree that a Mafia-type organization exists. They differ only on questions of detail and formal structure.

The activities of these organizations allegedly include gambling, loan-sharking, the import and wholesale of narcotics, labor union infiltration, coin-machine operations, laundry and other services, and manufacturing. The Mafia exerts control over senators, congressmen, state and local officials, as well as federal and local judges (Cressey 1969).

While there is general agreement that there are Italian-American crime families in the United States, there is strong disagreement on how tightly knit these organizations are on a national level or how different they are from other business arrangements made by non-Italian-Americans in the spheres of legal as well as illegal enterprise.

The nature of Italian-American family crime organization is explored from the Sicilian-Mafia perspective by Giovanni Schiavo (1962) who insists that the Mafia was disbanded by Mussolini in 1927 and that there is no reliable evidence of a Mafia in control of organized crime here or elsewhere.

Nelli (1970), in chroricling the rise of Italian-American crime families in Chicago, described the entrance into crime as necessitated by the limited opportunities available to the newly arrived immigrants. Most of the Black Hand activity involving violence took place within the 
Italian-American community. This view is consistent with general press accounts regarding alleged violent mob activity and is supported by Bell (1960). Bell suggested that crime business, like American business, has "shifted its emphasis from production to consumption", from areas like bootlegging to gambling (emphasis in the original) (Bell 1970, p. 119).

Robert Anderson (1965) suggested that The Organization has become more elaborate and more extensive with increased specialization and inevitable bureaucratiziation, coordination and control. In this process the organization has shifted its name from Mafia to Cosa Nostra. The traditional rural structure of the Sicilian organization has yielded to a far more diversified, rational and modern industrial form appropriate to the American city.

Ianni and Ianni (1972) cited the widespread nature of the Mafia story in American mythos from about 1890 on. In that year, nine accused assassins of the New Orleans police chief were lynched. Outraged, the Italian government caused the United States to pay an indemnity of $\$ 25,000$ to each of the three families of the Italian nationals killed in the mob action.

In examining the Lupollo family in New York, Ianni and Ianni (1972) found that traditional rules apply to alliances in a local or regional crime family. Such ties are based on kinship through blood and marriage and through ritual kinship or compareggio. Compareggio serves to bring together generations as well as lineages. There are also reciprocal obligations within families as well as across families. Where these first loyalties do not dominate, friendship, shared interest and selfinterest help to form new alliances outside the traditional forms. 
Operationally, the Lupollo family and other Italian-American crime families are social units with social and business functions merged. All leadership positions, down to "middle-management" level, are assigned on the basis of this kinship.

- The higher the position in the organization, the closer the kinship relationship.

- Leadership positions are assigned to a central group of family members, all of whom have close consanguineal or affinal relationships.

- Members of this leadership group are assigned to either legal or illegal enterprises, but not to both.

- Transfer of monies from illegal to legal and back into illegal activites takes place through individuals, and is part of the close kin-organization of the family (Ianni and Ianni 1972, p. 106).

Italian-American criminal syndicates are clan organizations with shared behavior and value systems. Organizations in different cities are brought together through blood or marriage relations. Marriage and blood relations "are actually a series of complex alliances binding lineages within the same family and allying families into what we have called clans, for the purpose of systematic exchange of services." (Ianni and Ianni 1972, p. 169)

The Italian-American organizations replaced the Jewish-dominated crime syndicates. Eventually families like the Lupollos became more and more "American" and legitimate in their enterprises.

The Mafia is a unique Sicilian institution reflecting the unique history of that land and:

The relationship between society and the development of the Mafia in Sicily holds true for organized crime in this country as well. There is no organized crime "underworld." Rather, organized crime is a result of an individualistic, predatory philosophy of success, the malaise of laissez-faire economic and political practice. Organized crime is that part of the 
business system operative in the illicit segment of American life. The degree and tenure of minority group involvement in this business enterprise is basically a function of the social and cultural integration of the group into American society. At their first entrance into this society, immigrants and their children grasp at the immediate means of acquiring what the New World has to offer. As they are acculturated, their crimes become more American and in time merge into the area of marginal legitimate business practice. Where one stops and the other begins is not always easy to see (Ianni and Ianni 1972, p. 61).

The survival of the Sicilian model in American life, the Ianni's argued, is not only due to homeland traditions but to the indifference of east coast Tammany organizations and law enforcement agencies to the Italian-Americans' plight in the ethnocentric and competitive urban centers of America (Ianni and Ianni 1972, Bell 1960).

As will be shown later in this study, the Mafia model is one among many types of organizations of criminal activity. No one ethnic group dominates crime and criminal syndicates throughout the entire nation. Ethnicity is a factor in both the organization and development of crime networks as Ianni and Ianni (1972) suggested. The public identification of all organized crime with the Italian-American community hides the nature of much of organized criminal activity. It reflects ethnic stereotyping while at the same time simplifying a complex pattern of activity and opportunity. It is important then to realize that:

VII. ORGANIZED CRIME IS NOT AN EXCLUSIVE PROVINCE OF ANY PARTICULAR ETHNIC GROUP. IT ARISES FROM ATTEMPTS BY NEW IMMIGRANT GROUPS AND OTHERS TO MAKE A CLAIM ON WEALTH AND POWER IN AMERICA.

The Local Cabal - Stern in Wincanton. Gardiner (1970) studied a crime organization with a Jewish leader in the fictionalized city of Wincanton. The Stern organization rose through gambling, principally on numbers. Extortion, intimidation and violence, as well as cooperation and syndication were used to extend and diversify Stern's interests. 
By the early $1960^{\circ}$ s the Stern organization was active in horsebetting, numbers, pinball, a large floating dice game and bootleg manufacture of whiskey. In the process of the organization's growth, Stern developed complex relationships with other businessmen, with important politicians and the law enforcement community. Mutually beneficial arrangements for political and eccnomic advantage were common.

Gardiner (1970) asserted that Stern operated independently of any larger national organizations. Yet Stern did have partnership arrangements with larger east coast operations. He also invested funds and laid off bets with organizations from other locations with larger holdings. When muscle was necessary, Stern hired outside enforcers. These men came from larger Cosa Nostra organizations.

Gardiner outlined a series of critical events that led to reform in Wincanton. The events span a period of mo:se than fifteen years. They begin with a Congressional investigation of June 1951. The Congressional comittee findings, which were released nine weeks before the city elections, indicated that the Stern Syndicate virtually controlled the city police in terms of gambling enforcement.

From 1956 to 1960 federal agents raided a tavern operated by then Mayor Donnelly and were able to establish a line between various city officials and the Stern group.

During the eight years of the Walasek and Whitten administrations (1960-1968), Stern and others were successfully linked to corruption in city purchasing and extortion. Indictments came shortly before primary elections in 1963 and 1967 . These repeated actions by the Justice Department, culminating in 1967 in a strong condemnation of corrution in 
Wincanton in the National Crime Commission Task Force Report on Organized Crime (1967) forced local attention to the corruption issue. All of these events were accompanied by media attention.

Gardiner argued that the federal revelations with their extensive media play were critical events which convinced voters to act to restore official morality and end corruption. This voter response took the form of a shift in party preference and the ousting of the old Democratic machine.

VIII.AUTHORITATIVE, EXTERNALLY ORIGINATED AND VERIFIED CONDEMNATION OF LOCAL CORRUPTION IS A MAJOR FACTOR FOR LOCAL REFORM.

Gardiner suggested there are three identifiable variables which reduce the likelihood of official tolerance of corruption existing in both law enforcement and other city agencies. These are: (1) Strong rewards such as job security, regular promotion, high pay and merit awards for good work beyond the standard; (2) High professional and public status and expectations; (3) Strong, clear supervision and chain of command.

IX. WHERE STRONG REWARDS, HIGH STATUS AND CLOSE SUPERVISION OF POLICE DO NOT EXIST, PAYOFFS AND CORRUPTION MAY TAKE PLACE.

The Seattle Network - Business as Usual. William Chambliss (1978) studied an organized crime network in Seattle. Focusing his study on the ways in which the legal system and law enforcement structure crime into various business operations including vice, Chambliss saw organized crime in Seattle as a cabal or coalition. It involved not only racketeers and gamblers, but politicians, union leaders and legitimate business people as well. Chambliss (1978) argued that large real estate interests, banks and savings and loans are usually involved in and gain from the activities of such cabals. 
In asserting a structural or functional notion about deviant acts, Chambliss (1978) used as an example an ordinance that forced nightclub operators to violate the law in order to make a profit. In Seattle, for an eating establishment to sell liquor a certain percentage of income must come from the sale of food as well. Chambliss pointed out that in order to make an adequate income, nightclub owners would have to be operating prohibitively large restaurants the size of a football field.

In order to circumvent the city ordinance, club owners would manipulate their books and lie about their business. Under these circumstances, they were vulnerable to accusations of code violation and criminal law violation. This situation created opportunities for bribes and payoffs to police.

X. VICE AND CORRUPTION ARE STRUCTURED, THROUGH THE POLITICAL SYSTEM AND LAW ENFORCEMENT, INTO THE OPERATION OF VARIOUS BUSINESSES. Chambliss pointed out:

In Seattle, the operators of cardrooms, cafes with pinball machines, taverns, nightclubs, bookmaking establishments and sundry other enterprises, which were in violation of one or more laws had to pay graft to keep open. There were two payments a month. (Chambliss 1978, p. 102).

Chambliss cited the Knapp Commission report on Corruption in the New York Police Department as further evidence of the commonness of corruption of the law enforcement community. Using a Marxist dialectical perspective, Chambliss argued that:

...Criminality reflects and stems from contradictions that are inherent in the political and economic structure of society. These contradictions create conflicts in attempts to resolve them. The resolutions forced in turn reveal other contradictions, further conflicts and more resolutions. In this way, the development and maintenance of illegal business and/or organized crime and criminal activities fit into, reflect, complement and mirror the political economy of our time (Chambliss 1978 , p. 8). 
XI. ORGANIZED CRIME, WITH ITS USES OF VICE AND CORRUPTION, IS NO DIFFERENT THAN OTHER FORMS OF BUSINESS EXCEPT THAT, BECAUSE THE CANNOT RELY UPON THE LEGAL/CIVIL SYSTEM TO ENFORCE THEIR BUSINESS ARRANGEMENTS, ORGANIZED CRIMINALS CAN AND DO RESORT TO THE USE OF VIOLENCE AND OTHER EXTRA-LEGAL SANCTIONS.

Chambliss (1978) described the collapse of a cooperative network of law enforcement agents, local politicans, vice operators and others in the late sixties in Seattle. Despite the occasional publication of stories on corruption, little in the way of effective publicity and consequent public arousal took place until a new editor, an outsider came to the second largest Seattle daily paper and began a series of exposes on meetings of the prosecutor with the leading figures in local vice operations. At the same time, a local magazine, which served a largely new professional middle and upper class clientele, published material on the corrupt connections in the city.

The subsequent shake up, demanded by a new sense of public outrage, resulted in the indictment of fifty-four public officials. Yet, the previous political arrangement which divided power between the statedominating Democrats and the city-ruling Republicans, was altered only to a small degree. Chambliss stated that a year later a new network involving the same positions and crime group was developing often using a new set of officials. Patterns of tolerance and accommodation survived because it was necessary for the political health of all groups whether traditional rivals or not.

In the end, in Seattle, none of the more important figures at the top of the corruption pyramids were convicted, though three policemen of high rank were. Only one racketeer was convicted. He did two years and a month of a three-year federal sentence (Chambliss 1978). 
XII. A VICE PROBE WILL AFFECT THOSE INVOLVED IN INVERSE PROPORTION TO THEIR POWER, PRESTIGE AND WEALTH.

\section{The Media and Modern Reform}

It has already been shown that public perceptions of organized crime are influenced by what is written or presented through popular media sources. Miller (1968) and Gardiner (1970) and Chambliss (1978) indicated the role that the newspaper and other media sources play in reform efforts.

Walter B. Miller (1976) examined the apparent appearance and disappearance of violent youth gangs in New York City through the '50's, '60's and '70's. Using newspaper stories, Miller showed that media coverage of certain types of gangs follows a pattern of "a period of virtually no attention, and a period of renewed attention" (Miller 1970, p. 97).

In his study, Miller found that stories of violence have evident audience appeal and are used therefore frequently in the press and on television. Thus, when things were peaceful in the 1950's, gang violence, lower on the scale of violence than war or major disaster, became headline material. In the $1960^{\circ} \mathrm{s}$ when urban riots and student demonstrations took place, gang violence was driven from the headlines. By the $1970^{\prime}$ s, with civil disruption and the Viet Nam war dying down, gangland violence returned to the headlines. This was true, Miller asserted, despite figures that indicate that gang violence was a continuing problem in ten major metropolitan areas throughout all three decades.

Public perceptions, Miller showed, followed media attention. The media tend to pay attention to the new in the world of violence; 
therefore, when gang violence makes it to the front page due to a lack of more exciting material to replace it, such gang activity is portrayed as new.

Since the investment in newness as a salable commodity is generally coupled with a short time perspective, periodic elaborations of gang behavior are seized upon and marked not as recurrent stylistic variations on a continuing pattern but as the new, the spectacular, the sensational (Miller 1976, p. 120).

Media attention functions as a device, according to Paul Lazarsfeld and Robert K. Merton (1952), to force a noncontradictory single morality on public issues. The media serve to affirm public norms through exposure of deviance. They also can serve, as Michael Lipsky (1968) suggested, as a path to redress of grievance by relatively powerless groups.

XIII.MEDIA ATTENTION SHAPES PUBLIC CONSCIOUSNESS OF A SCANDAL; THIS IN TURN IS A FACTOR IN FORCING OFFICIAL ACTION.

Dumhoff (1978) found that much of the process of political and economic policy making for urban centers took place in informal settings. Exclusive clubs and social events formed the backdrop for many of the relationships that were the cement bonding ruling class interaction on the social and the decision-making level.

Mills (1956) discovered whole networks of informal as well as formal contacts operating in the context of dominance by elites in the political and economic life of the United States. Both Mills and Dumhoff saw in the dimension of informal social activity the opportunity structure for the processes of handing down and maintaining a coordinated set of actions, beliefs and positions. 
If, as is suggested by proposition XI, the behavior of criminal businessmen is little different than that of their legitimate counterparts, then, given both the usefulness of criminal businesses and their frequent involvement with the politically powerful, there will develop informal social interaction among and between both groups. This is confirmed by Bell (1960) and Chambliss (1978).

XIV. INFORMAL INTERATION BETWEEN ORGANIZED CRIME FIGURES AND OTHER ELITES DO EXIST AND ARE USED IN MAINTAINING POLITICAL CONTROL.

Thus far this Chapter has emphasized the cooperative nature of relations between criminal groups and city government. It has been suggested that conflict develops from outside the city itself, from within, as in the case of the rise of new elites, and/or in the process of media attention given to such events.

\section{Outsiders and Reform}

Both the Marxists and the Functionalists see the usefulness of existing arrangements involving corruption and vice to the maintenance of status quo. Bell (1960) suggested that in the course of the rise of the labor movement a new corrupt power developed. This force, seen most notably in the Teamsters Union, offered some potential for challenge to existing arrangements in the operation of vice and corruption in many cities. Teamster power exists, Bell (1960) suggested, because of the union's ability to control delivery of necessary goods and because of its structure of regional independence.

Bell (1960) saw the rise of Teamsters as part of the occasion of governmental examination of labor in the mid-fifties. The movement of the Teamsters in local, state and national politics is documented as a factor in vice and official corruption in Seattle by Chambliss (1978). 
XV. THE ATTEMPT OF A NEW ELEMENT, SUCH AS A POWERFUL LABOR UNION, TO ALTER EXISTING ARRANGEMENTS AMONG CITY OFFICIALS AND ORGANIZED VICE OPERATORS IS A FACTOR IN CAUSING REFORM.

Gardiner (1970) suggested that when enough effective evidence has entered the public consciousness to create an undeniable sense of the failure of the system to deal appropriately with what is seen as a shared set of moral value violations, there develops a public consensus on the issue and a clear demand for reform. Coleman (1959) emphasized this consensual phenomenon, seeing it as affected by such dynamics as community identification with its leaders and the relative importance of the issue in the public's ideological perspective.

XVI. WHEN THE SUM OF THE FACTORS REVEALED TO THE PUBLIC IS SUFFICIENTLY IN VIOLATION OF IMPORTANT MORAL VALUES, PUBLIC MORAL OUTRAGE DEVELOPS. THIS OUTRAGE IS THE BASIS FOR A POPULAR CONSENSUAL DEMAND FOR REFORM.

Chambliss (1978) and Coleman (1957) found that even under the circumstances of a public consensus for action, such action may be individualistic rather than systemic as is suggested by propositions XIII and XIV. 


\section{CHAPTER III}

\section{METHOD}

This examination of a vice probe in Portland, Oregon is an historical case study of an instance of public revelation of alleged vice activity in a city of approximately cne-half million people during the mid-1950's .

The case study model is a well-known and utilized method in historical, sociological and political science research. The techniques used in case studies, whatever their disciplinary bias, have certain similarities. This study, therefore, uses a number of techniques familiar to social science.

\section{The Triangulation of Sources}

Several social scientists have pointed to the advantage of using more than one method or source of data collection as a way to validate data gathered in field research. The tecinnique is called triangulation, or the multi-method approach (Campbel1 and Fiske, 1959; Sieber 1973; Smith 1975).

In the present study, the history of the focus incident was reconstructed by approaching it from three data sources: (1) Accounts in the mass media, represented mainly by articles carried in the two major newspapers published in Portland during the event; (2) Government documents which resulted from the official investigations of the incident and from other archives; (3) Interviews done by the author with persons who 
were involved in the incident as actors or who had some other knowledge of events connected with the focus incident.

A first-order triangulation of sources combined data from the mass media, government documents and interviews in a search for convergent and divergent facts; that is, to find points of consistency and agreement as well as ones of inconsistency and disagreement among the three data sources.

By bringing to bear three separate data sources in the case study and by comparing one with the other, events can be examined not only in terms of the limitation of official documentation, but in terms of the memories of individuals around whom the events occurred. Since memories are notoriously uncertain, the interviews can be checked against the archival record, against the findings of offical investigations and other interviews, which, in turn, can be checked against the popular record, against press accounts and other accounts available through the printed media.

It was also possible to carry out a second-order triangulation technique within each of the three data sources. The details of this second-order triangulation will appear in the extended description of the three data sources which follows.

The Data Sources

Accounts in the Mass Media. The first source of data used to construct the historical case study were the set of popular accounts in the mass media published during the time of the event. This includes the reports and investigations of the two major daily newspapers published in Portland at that time and also other background material on the power 
structure of Portland, derived mainly from a number of newspapers and magazines published in the same city.

The two major daily newspapers in the city took opposing sides during the vice probe. From this adversary context there emerged what was practically a "prosecution" and "defense" version of events in the two papers, bringing into high relief the points of general agreement and those facts in doubt. This was the main basis for the second-order triangulation done within this data source.

In using newspaper and other popular accounts, certain problems of contamination arise. If, for example, Newspaper $A$ gives an account of an event or set of events and is read first, the second account in Newspaper B, an account which may differ in part or in the main, may seem less valid, less real to the researcher. Conversely, if $B$ is read first, then A may well be suspect. In any event, there is an element of contamination in the process of examining contradictory accounts.

In order to deal with this problem, the author has employed the following technique: after initially reading accounts of alleged events surrounding the vice probe, a summary was made of what was considered to be the major points in contradiction and in agreement in the two major newspaper accounts. Setting this aside, an independent observer was brought in to read one version of the vice probe in the afternoon newspaper. A summary, including all names, dates and places, was made by the observer. The observer was a graduate student from a midwestern university, knowledgeable in research procedures, who had no familiarity with Portland's politics in the nineteen-fifties, and was unaware of the events described. The observer described the events as presented in the afternoon newspaper and this summary account was compared with the 
account made by the author. Differences were noted, and adjustments were made to the first account based upon the account of the independent observer. A presumption was made that the independent observer's account would be less biased and less subject to contamination than the author's. This check insured that such contamination had been eliminated as much as possible.

A second independent observer, also with no knowledge of activities in Portland, was brought in to read the accounts of the morning newspaper and, made a similar summary of all relevant facts, dates, places and persons. This account was compared with the understanding of the author.

Government Sources. The second source of information was government documents: the attorney general's files in the Oregon State Archives; lists of office holders, major appointments to commissions and committees of Portland's government; land holding and sales records; and records of the U.S. Senate Committee on Improper Activities in the Labor or Management Field.

Access to the Attorney General's files in the Archives of the State of Oregon provided much information. Files dealing with the vice probe alone took up more than 68 boxes of material involving literally tens of thousands of documents. Fortunately, much of that material was redundant and after an initial search, attention could be narrowed to less than 20 boxes of material. Included in this material were:

1. A final report on the probe by the Attorney General and final reports by members of his staff;

2. The verbatim transcripts of several of the grand jury interviews; 
3. Grand jury reports to presiding judges;

4. Interviews by attorney general and state police staff with principals, witnesses and informants;

5. Various vouchers, bills and the like relating to vice activities and state investigative costs;

6. Original prepublication versions of various news stories and reporters' notes; and

7. Thirteen surviving reels of tape recordings of which only 9 proved to be at all intelligible even in part. (These recordings were those allegedly made by James Elkins' employee, Ray Clark, at the King Towers Apartments. Many tapes referred to in the course of the investigation and quoted verbatim in the press are not part of the material found in the Archives. The wiretap wire recordings which led to federal wiretap charges were not among these files.)

This material is referred to in the bibliography by its accession number.

The diverse materials on the vice probe contained in the archives provided many opportunities for the second-order triangulation of information within this data source. These included the comparison of testimony by different persons, the comparison of testimony by the same person on different occasions, the consistency of reported facts with records and documents, and the evidence from recorded conversations.

The government records, of course, also played their role in the first-order triangulation of the three main data sources.

A major land development scheme, the creation of a new public coliseum (Exposition-Recreation Center) on lands in which there was 
alleged improper speculation by a participant in the ExpositionRecreation Commission, and vice leaders of the Portland metropolitan area is involved in the vice probe according to the morning paper. Certain outsiders were alleged to be moving in on the vice scene in Portland and alleged to be participants in vice activity with the Teamsters Union, but the two local papers disagreed on many of the facts. The U.S. Senate Select Committee on Improper Activities in the Labor or Management Field (1957) also heard a number of allegations on this land speculation matter. Land records and purchase agreements and other records on land possession were examined as a check on the veracity of accusations made both in the press and through the Senate Committee.

Respondent Interviews. The third source of data were interviews with persons familiar with the probe at the time, and persons who could relate second-hand information through family or other contacts. Primary interviews came from those who could give first-person accounts, including reporters who composed the original articles on the subject; persons directly involved in vice activity in Portland at the time, persons involved in law enforcement in Portland at the time, state and local politicians and lawyers. A group of secondary interviews, while few in number, were significant in nature. These are interviews of relatives, friends and others who recall not only the flavor of, but specific instances relating to persons of some prominence in the vice probe. In addition, several tertiary interviews were conducted to verify the accuracy of key informants. These last were interviews with persons familiar with specific events in general terms who, while knowing nothing of special events, could substantiate points in other areas which, in turn, could confirm or bring into question the respondents' recollections. 
Respondent Selection. Interview respondents were selected from a limited population made up of those persons who could be found who were involved in or had direct knowledge of the case under investigation or those who could add corroborative information on the veracity of this first group. Since the case under investigation took place twenty-five years ago, time and physical mobility have further reduced the available respondent population. Accessability and survivorship set natural limits upon available interview respondents.

Respondents were located through media accounts of the case through the reports of the U.S. Senate Select Committee on Improper Activities in the Labor or Management Field (1957) and through archival sources. As interviews progressed, other names were suggested. Where possible these persons were also contacted.

\section{Interview Technique}

Potential respondents were told that the vice probe and corruption expose of the mid-nineteen-fifties was under study as part of a doctoral disseration in Urban Studies at Portland State University. A brief summary of the event, including a list of more prominant names involved was presented and the respondent was encouraged to tell what they knew of the events. The interview used an open format. Specific questions were asked where they appeared appropriate. The respondent population fell into two groups by the nature of their career patterns. The first group, persons active in public life at the present time or in the past, included media reporters, politicians, command level law enforcement personnel and career government professionals. The second group, persons of one time notoriety or unknown to the media-reading public at 
the present time, included one time illegal or fringe business people, vice service users, non-command level law enforcement personnel and relatives of those involved in the case in the mid-nineteen-fifties.

In the open-ended interview there are no specific sets of questions asked. Instead, specific areas of interest are covered. Questions designed to gain this information are short and designed to initiate lenghty descriptive responses. Informant interviews generally began with this question: Can you tell me what you remember about the vice probe that took place around 1956 in Portland?

This question would be followed by others. The nature of the follow-up questions would depend on the length and degree of detail provided in answering the first question. For example, when a black informant suggested that there was a cooperative control network in Portland involving the white power structure, the informant might be interrupted and asked: Who was in that power structure?

If an informant suggested that there were payoffs, the questioner would attempt to get the informant to specify what he or she knew from what they had heard. For example: Do you know of times when payoffs were made?

This question might be followed by a question encouraging a specific answer like: How were the payoffs made? Or: How much money was involved?

Generally interviews moved from the general to the specific and back again. Every attempt was made to keep the interview on relevant topics, although occasional digressions revealed unexpected information and insights. When this happened, the digression was encouraged. 
In order to protect these sources' anonymity, the following procedure was used: All interviews were tape recorded and transcribed except where respondents requested that this not be done. Members of the second group were not identified by name or other significant designation in the study itself and at the conclusion of the study, the tapes and transcriptions of the tapes were destroyed.

It must be emphasized that all respondents were informed of the nature and purpose of the study. All respondents were not naive subjects. All showed a complete and sophisticated understanding of the implications of cooperation with this research. They proved well informed and able to decide for themselves whether and to what degree they would cooperate. Several refused to respond or answered only a limited number of questions, reserving some information from the interviewer.

To further preserve the privacy of the respondent groups, only a very limited categorical list of respondents is given here. A list of persons active in public life, appears in the bibliography identified by name. 
TABLE I

\section{INTERVIEW RESPONDENTS}

BY CATEGORY

\begin{tabular}{lcccc}
\multicolumn{1}{c}{ Category } & $\begin{array}{c}\text { Primary } \\
\text { Sources }\end{array}$ & & $\begin{array}{c}\text { Secondary } \\
\text { Sources }\end{array}$ & $\begin{array}{c}\text { Tertiary } \\
\text { Sources }\end{array}$ \\
Media Sources & 6 & 3 & 2 \\
Attorneys & 5 & 2 & 2 \\
Law Enforcement & 4 & 2 & 4 \\
Elected Politicians & 5 & & \\
$\begin{array}{l}\text { One Time or Present Fringe } \\
\text { Business People }\end{array}$ & 6 & & \\
$\begin{array}{l}\text { Vice Service Users } \\
\text { Friends of Those Involved }\end{array}$ & 12 & & 4 \\
Relatives of those Involved & $\underline{2}$ & $\underline{3}$ & - \\
\multicolumn{1}{r}{ Total } & 40 & 12 & 12
\end{tabular}

The situations in which interviews took place were often informal. Generally, interviews were tape recorded, but if respondents requested that the tape recorder not be used and/or that notes not be taken, the interview was still carried out. In some cases notes were then made from memory directly after the interview. For the most part, however, interview subjects allowed tape recording.

Difficulties and advantages of interviewing techniques are detailed in the book Elite and Specialized Interviewing by Lewis A. Dexter (1970). Dexter pleads for a great deal of flexibility in interviewing techniques and cites Nadel's (1939) article "The Interview Technique in Social Anthropology." 
In dealing with important personages, Dexter (1970) emphasizes keeping the interview confidential and limiting knowledge of who was interviewed and what was said to those who have an absolute need to know.

Some Comments on Interviewing. The importance of oper-ended questioning, of patience in the interview situation, is emphasized by Charles Morrissey (1970).

On the question of the kind of truth one gets from interviews, John P. Dean and William F. Whyte (1970) said:

In evaluating informants' statements we do try to distinguish the subjective and objective components. But no matter how objective an informant seems to be, the research point of view is: The informant's statement represents merely the perception of the informant, filtered and modified by his cognitive and emotional reactions and reported through his personal verbal usages. Thus we acknowledge initially that we are getting merely the informant's picture of the world as he sees it. And we are getting it only as he is willing to pass it on to us in this particular interview situation ( $p .120$ ).

In the process of interviewing diverse subjects, a second order of testing naturally develops. The reality of the "assertions" can be checked against recollections presented by others and by printed sources. This does not mean, however, that contrary stories and interview information can be safely discarded. Rather, decisions must be made as to whether such information is significant and of adequate value for the research at hand. Does it open up new vistas of information? Does it suggest ideas that were previously missed? Is the countervailing position held in the interview possible, likely, given what is known of the circumstances? $0 r$, is it simply the faulty recollection or personal bias of the interview subject? Even in the last instance, the interview can reveal the subject's own perception of events or expose his methods. 
As Douglas (1976) suggested, a tough-minded attitude is very important in this kind of research. He pointed out that questions should always be asked in terms of assumed activities or events. For example, such questions as, "Where does the money come from?" in dealing with whores and pimps, become of particular significance. How, exactly, are the economic mechanics of the activities explainable? Douglas suggested that researchers must examine a given activity from all angles; from the legal, the economic, personal pleasures, and so on. He suggested that a check against interviews by similarly knowledgeable persons regarding the accusations and suggestions be made in the course of the interview. This type of interview was carried out as well as suggested earlier.

The use of friendly trust and the guarantee of privacy were more important to most interview subjects than any other single factor in their granting of an interview. One newspaper reporter, however, who was initially thought to be very important to this study, refused to grant an interview because of his position with a major east coast metropolitan newspaper. As west coast editor for this newspaper, he felt that his contacts in Portland would be jeopardized if he gave an interview, although the events in question had taken place more than 25 years ago.

During the course of the interviews, many difficulties were encountered, not the least of which was that most lesser known respondents proved unwilling to sign any kind of release form, either before or following the interview. While many were willing to discuss what they knew, they were very reluctant to put their names to any document relating to the case. In most instances these respondents insisted that whatever safeguards were provided by the university, either traditionally or in a nontraditional context, were inadequate. It was 
for this reason that interviews were erased from tapes following transcription and that no identity was made of such respondents so that no check would be possible upon who was giving what information it some later date. The necessity of this in ethical terms was absolute; there could not be any possibility of a check back on who was giving what information lest there be a betrayal of confidence which might have immediate political or other consequences for the interview subject.

How does one know when one has gained the complete story? How, in short, does one know when to stop interviewing? This problem is addressed by Glaser and Strauss (1967):

The criterion for judging when to stop sampling the different groups pertinent to a category is the category's theoretical saturation. Saturation means that no additional data are being found whereby the sociologist can develop properties of the category. As he sees similar instances over and over again, the researcher becomes empirically confident that a category is saturated ( $p$. si).

This technique was used in deciding when to stop interviewing respondents. When repetiton of detailed versions without significant new detail occurred throughout five interviews interviewing was stopped.

\section{Method Summary}

By using a balance of triangulated data, this dissertation avoids an error pointed out by Dexter (1970) - reliance on interviews without enough relevant background information. Such a reliance totally upon hearsay and elite interviews without specific archival or other forms of information against the interviews should be avoided (Dexter 1970).

As stated earlier, there are three basic sources of material for this disseration: 
1. The media - popular cultural sources, newspapers, magazine articles and the like. Access to the morgues of the newspapers permited an extensive examination of the available popular cultural sources. Systematic sweeps of categories on the basis of names indicated from other sources, together with general category and event-related sweeps of the available morgue materials, have been done. The result is the creation of two separate and somewhat contradictory sets of facts and interpretations.

2. Public agency documents - court records, land records, the attorney general's files in the Oregon State Archives, the Senate Hearings of the Select Committee on Improper Activities in the Labor or Management Field, 85th Congress (1957).

3. The accounts, both tape recorded and constructed through notes, of individuals whose association with the vice probe at the time was one of two types: either as an active participant from law enforcement, from the vice area, or from the newspaper business; or as a person who knew active participants, a secondary source. 


\section{CHAPTER IV}

\section{HISTORY OF THE VICE PROBE}

A brief look at Portland's governmental history is useful in understanding the situation that forms the background for vice in the city.

Before 1913, Portland had a ward system and a fifteen-member city council, with several boards and commissions exercising often unsupervised and overlapping authority, and an executive whose responsibilities were unclear (City Club Report May 14, 1961).

Following a report by the New York Bureau of Municipal Research alleging numerous deficiencies in several aspects of city government and which was issued at the height of the municipal reform movement, the city adopted a new charter by a narrow margin -- 722 votes out of 33,406 cast. Only about $22 \%$ of those eligible had voted. The report was contracted for by Oregon Journal publisher C.S. Jackson, who had formed a panel of leaders to look at city government (MacColl 1978).

Portland was among 200 cities which adopted the "Galveston Plan" of municipal government (City Club Report May 19, 1961). However, the commission form fell under heavy attack in the ensuing years and barely survived an attempt to change it in 1917. A group of prominent north Portland citizens tried to persuade the electorate to adopt a 200-page charter revision that would have restored the old eleven-member parttime council. Six months earlier, another group had proposed a city manager form, the Dayton Plan. Both initiative measures were defeated in the June 4, 1917 election (MacColl 1978). 
Having survived attempts to abolish it, the commission form has continued with minor changes. The mayor and four-member council are elected at large in even years on a nonpartisan ballot for four-year staggered terms (City Club Report, May 14, 1961).

This council both legislates and administers the city departments. The mayor has additional power to assign which bureaus are run by which commissioners.

In the interval since adoption of the commission form, the prestigious Portland City Club has produced more than 60 reports dealing with problems of municipal organization and operation. Citizens numbering in the hundreds have served on the Club's standing committees to produce the reports, but despite this, no real changes have been effected (City Club Report, May 14, 1961).

Over the years, the reports have charged the city with lack of top management organization, lack of planning in city physical patterns and controls, lack of fiscal planning and lack of organizational planning (City Club Report, May 14, 1961).

Overview of the Portland Vice Probe of 1956-1958.

The Portland vice scandal broke in the Oregonian on April 19, 1956. The Oregonian story was based on clandestine recordings made by James B. Elkins, local underworld figure, which supported his claims of behindthe-scenes manipulations, payoffs and corruption involving local racketeers, the police, political figures at all levels of government and Teamsters Union leaders.

The attempt of the Teamsters Union to move into the Portland vice arena, as alleged by Elkins and supported by others, was the central 
issue presented by the Portland probe. Elkins' veracity or lack thereof is the issue around which the two daily papers, the morning Oregonian and the evening Oregon Journal, fought a bitter journalistic and extrajournalistic war. At stake eventually was the credibility not only of Elkins, but the new mayor, the district attorney, elements of the state government, the justice system and the papers themselves.

The Oregonian, a Republican paper, took the part of Elkins. The Senate Select Committee on Improper Activities in the Labor or Management Field (1957) also accepted his version of the vice situation in Portland. (Incidentally, the Senate Hearings introduced into the public consciousness a new name--Senate Counsel Robert F. Kennedy.)

The Journal, on the other hand, saw Elkins as a lying outlaw who was trying to protect his own activities and those of certain members of the city and state governments, particularly the police department, the Oregon Liquor Control Commission (OLCC) and quite possibly the mayor's office, which they believed were cooperating in allowing Elkins and others to operate.

The U.S. Senate Select Committee on Improper Activities in the Labor or Management Field (1957), believing Eikins', attacked the new mayor of Portland, Terry Schrunk. In doing so, the U.S. Senate Committee created a situation in which the local Portland leadership perceived itself as under external attack from outside forces which it saw as far more dangerous than any local threat at the time. For local leaders, whether of the old Republican organization or the new Democrats, the danger reprsented by an alleged Teamsters takeover was ended.

This historical case study examines the Portland vice probe of the mid-1950's from four major perspectives: 
1. The viewpoint of the Oregonian and the U.S. Senate Select Committee on Improper Activities in the Labor or Management Field (85th Congress 1957) (essentially the perspective of James Elkins, that the Teamsters were trying to take over the local vice scene);

2. The viewpoint of then Oregon State Attorney General, Robert $Y$. Thornton, which emphasized the role of both papers in actively pressuring for their versions;

3. The viewpoint of the Oregon Journal and its reporters (asserting that Elkins was dishonest and that the vice problem was centered around Elkins and his associates);

4. The perspective of Mayor Terry Schrunk's mentor and advisor, Raymond Kell (arguing that the Oregonian's interests brought together a number of otherwise unrelated events into what was perceived as a particular pattern of corruption and conspiracy. Kell saw Elkins not as the Oregonian projected him, as a major figure, but as a third-level self-starter).

Other positions and information are presented to both challenge and confirm several aspects of one or more of these perspectives.

The Second World War and After 1940-1948.

During the war years Portland underwent an enormous transformation. In a city with a reputation as being "open," the development of Kaiser Shipyards and of other large war plants meant an influx of new labor.

Upon arrival, labor contractors would direct workers, based on their skills, first to the best of the local firms, and then finally to the Kaiser Shipyards. For long-term residents there was particular 
status attendant upon being a worker for one of the permanent local firms as opposed to the larger, transient firms like Kaiser. Thus, black informants in interviews emphasized that they were employed by local firms, whether their positions were as janitors or skilled laborers (anon.-Uris interview 1980).

Prostitution, gambling and drinking boomed. Portland was tolerant, a wide open town (Kell-Uris interview 1981; anon.-Uris interview 1979).

War Housing - an Example of an Informal Control Network. During the war, in response to the influx of new workers and their families, public housing under the Housing Authority of Portland (H.A.P.) was created. While the housing issue is peripheral to this study, it does serve to illustrate both the power relations and the informal method of their implementation in Portland.

The Housing Authority included leaders of the Oregon Apartment House Association, Chester A. Morris and Herbert J. Dahlke. By 1944 Chester Morris, Aaron Frank and David Simpson (of Norris, Beggs and Simpson, Realtors and property managers) urged that the Vanport public housing project be cleared as soon as the war was over (MacColl 1979).

These new workers, many of whom brought their families as the war went on, were unwelcome as long-term residents. They included in their numbers blacks as well as whites. In Portland's black community, elites were contacted by the white elites. These informal contacts were used to maintain both the temporary nature of the new population and to keep it racially segregated.

A black informant described how he and other black community leaders were invited by the white elite to a meeting in the board room of the First National Bank. There they were allegedly greeted by civic leaders, 
including E.B. MacNaughton, President of the First National Bank. They were told that while housing was being prepared for white workers, it was expected that black workers would be placed in the homes of the existing black community. They were assured at that time that such black boarders would be temporary residents of the community and that the purpose of not building adequate housing for these workers was to ensure that their presence in the community would indeed be temporary.

The informant, a close relation of a prominent illicit entrepreneur, said that he was the only member of the black leadership who had been selected to attend the meeting to object to the procedure. Resistance within the black community was adequate, however, to prompt a change in plans which allowed blacks into Vanport, the public housing city to Portland's north. It was segregated however (anon.-Uris interview 1980).

The gathering in E.B. MacNaughton's board room suggests two things of importance to the study of the Portland vice probe:

1. The close, informal power relationship between the upper-class elite and other elites, some of whom operated outside the law; and

2. That there was an interlocking network of elites much like Domhoff's (1970) model and Chambliss' (1978) Seattle analysis.

Thomas Johnson - Tolerated Illegal Entrepreneur. It was through the process of the selection by whites of blacks to represent the black community that Thomas Johnson gained some of his power beginning in the 1930's.

Johnson operated numerous speakeasies and was a bootlegger serving all classes, whites and blacks, through the 1920's and 1930's. Tom 
Johnson's importance to the black community is legendary. Many Portland black persons who remember the war years have heard of Tom Johnson. He served interests in both the white and black communities.

For the white elites, Johnson, through his informants and his power within the vice arena in the black community, kept tabs on blacks entering and leaving Portland. He could help maintain order within the closely knit social community of the black neighborhoods. He was, then, a crucial link between the white establishment, its politicians and its law enforcement. Whites like James Elkins served a similar underworld function for the Portland police (black informant interview 1980).

Tom Johnson, his family and associates served the interests of the black community by relaying information, requests, dissatisfactions within the black community, up through the white law enforcement, political and other influential communities. Grievances and economic needs could thereby be addressed. A network of communication, exchange and complex power relations was thus developed.

Johnson, as the operator of the Keystone Investment Company, is reputed today to have been many times a millionaire. He eventually figured as a major partner in the effort to make a profit from the location of the E-R Center (the Memorial Coliseum) between the Broadway and Steel bridges.

As mentioned in an earlier section, Johnson's usefulness can be understood in terms of latent and manifest functions (Merton 1949). While Johnson was never an elected or appointed official, and while he was never a "boss" in the sense of men like Tweed, he nevertheless served many of the functions of a "boss" within the black community of Portland. 
The 1948 Reform Movement

Earl Riley was Mayor of Portland from 1941 to 1949 and, under Portland's Mayor/Council system, controlled the police department. His chiefs were Harry Niles and Lee V. Jenkins.

By 1947, following the murder of a ship's captain, Frank B. Tatum, who was last seen alive in a local vice spot, there were persistent rumors of police corruption. Consequently, an investigative report was prepared by August Vollmer, then retired Chief of Police of Berkeley, California.

In his report, Vollmer suggested that "the Portland Police Department was over-costly, under-protective, poorly organized, inadequately supervised and underpaid" (MacColl 1979). Vollmer pointed out that the Portland crime rate had risen steadily for the preceeding ten years. He emphasized that there was lack of professionalism and low salaries. He recommended that foot patrols be expanded and policemen be better paid.

The Portland vice situation did not become an important public issue until early in 1948 when the Portland City Club, a civic organization noted for its responsible examinations of city problems and suggestions for city operations, published a report extremely critical of Mayor Riley's police force and of Mayor Riley himself.

The City Club report followed by approximately one year the murder of Tatum. The Vollmer Report and the City Club reports, both in part responses to this death, changed public attitudes toward the police and the mayoral race in Portland in 1948. 
The City Club report suggested eight major problems or findings:

1. Syndicates controlled gambling completely and were exacting tribute from gamblers -- slot machine owners paid $\$ 50$ a month per machine, dice table owners were paying $\$ 50$, and so on.

2. Mayor Earl Riley had failed to assume direction of the police department in his duties, he failed to consider the police department's importance in the scheme of city government, and he was inadequate in his supervision.

3. Payoffs had placed police authorities under obligation to criminal elements and police immunity had led to many opportunities for criminal activity to flourish. Personnel had been shifted in the police department to make it easier for gamblers, bootleggers and pimps to operate.

4. Portland had become a dumping ground for dope, bootleg activities, prostitution and the like.

5. State and local officials were actively participating in and protecting horse and dog gambling and the state liquor monopoly.

6. During the period from 1943 to 1945 , one group controlled all gambling, bootlegging and prostitution in the city, and in fact, its position was caided and abetted and defended by the police department; illegal and legal confiscations of equipment of opposition operators were routine during those years.

7. The police department sent out orders as to when vice establishments could operate, when they should be closed. Beat patrolmen exacted their own small payoffs, ranging from $\$ 10$ to $\$ 50$ a month from those operations.

8. When the police did raid syndicate joints, such raids were a farce. The proprietors were informed ahead of time, equipment was moved out and the only persons arrested where bums off the street. (City Club Bulletin February 20 1948).

In response to the City Club's accusations, Mayor Riley suggested that City Club members and their investigators (including by implication the reports investigator and later city council member, Stanley Earl) were in league with the gamblers controlling the city government (Oregonian, February 16, 1948). 
The City Club Bulletin (February 20, 1948) alleged that major city figures were supportive of the gambling interests. Portland's leading citizens were quite tolerant of vice activity to their own profit. For example, Norris, Beggs and Simpson, was headed by one of Mayor Riley's confidants, David B. Simpson. Organized vice provided high profits to operators, property owners and their managers. Norris, Beggs and Simpson were among many to profit economically by such activities (MacColl 1979).

The police themselves received approximately $\$ 60,000$ a month in protection payments according to the Oregon Journal (February 15, 1948). Portland had the honor of having the second highest incidence of venereal disease in the nation at the time (Gunther 1947).

Press coverage of these problems was never lacking. The City Club pointed out in its report that 95 major press releases over a span of 12 years referred to some aspect of the problem (City Club Bulletin February 20,1948 ).

Despite the Vollmer and City Club reports, when finally a crusading mayoral candidate was found, she was not supported by many in the business community. Dorothy McCullough Lee had served previously on the city council, and had a spotless reputation, a stern demeanor and rather Puritan morals.

Earl Riley's campaign support came from many prominent Portland businessmen and bankers. Among those supporting Riley were: the president of the Portland Chamber of Commerce, Hillman Lueddmann; former Chamber presidents Chester Morris, David B. Simpson, Arthur I. Field and Sid Woodbury; president of the U.S. National Bank, E.C. Sammons; president of the Benjamin Franklin Savings \& Loan, Ben Hazen; Iron Fireman executive $T$. Harry Banfield (for whom a freeway would later be 
named); architect Glen Stanton; retailers Aaron Frank and Fred Meyer; and contractor L.H. Hoffman (MacColl 1979).

These Portland civic leaders were all involved in one way or another in property management, and they all apparently stood to lose as a consequence of negative publicity about vice, and perhaps to gain in real estate involvements with the very lucrative vice operations (MacColl 1979).

Mayoral candidate Dorothy McCullough Lee was a wild card thrown into the city's political game. Her announced intention during her 1948 campaign was to shake up the organization of city government and to make major reforms, to name names and to change the nature of the relationships that had been long developing between the licit and illicit business communities. The business community's response to this--public support for Riley, her opponent--was not unexpected.

When Lee assumed office in 1949, she was harrassed continually. Her personal appearance was vilified in the press; she was mocked, partially because she was female, but also because of her position on vice. She was called "No Sin Lee" and "Airwick Lee." She had to send her children away to boarding schools in Canada to protect them from what she considered to be very real threats against their lives (Lee-Uris interview 1980; MacCol1 1979).

Conventional sources (MacColl 1979) show that Lee did clean up the police department. She appointed a new chief of police, Charles Pray, a professional policeman and retired state police executive. She brought into active involvement in police affairs a professional staff including Donald MacNamara, later chief under Mayor Terry Schrunk. She raised the salaries of policemen. She ordered the padlocking of various vice operations throughout the city. 
Many, including MacColl (1979), suggest that the consequence of this effort was a cleanup of Portland vice. Two informants (Kaplan-Uris interview 1989; Lambert-Uris interview 1979) suggested that Lee rid the city of vice to a great extent. Other informants indicate that this was not quite the case. Only visible vice disappeared. Some houses of prostitution, gambling joints and after-hours liquor places closed for long periods of time. Some operators moved outside the City of Portland into the county. Vice activities continued either outside the county or in parts of the city less exposed, such as north Portland. Vice activities in the black community were not severely reduced by her actions (anon.-Uris interview 1980).

A black informant who in those days operated an unlicensed nightclub for black patrons only, said that the legitimate establishment had a cooperative, economically beneficial understanding with vice operators. This understanding allowed not only mutual profit, but cooperation in the election of city officials. Elected officials, he related, were often chosen by the vice people with the approval of the legitimate business community (anon.-Uris interview 1980).

In the interview, this informant said Lee's mayoralty was a reform that changed the visible aspects of the vice situation but did nothing to change the essential reality of power in Portland. He said there was a cooperating syndicate dominating vice as suggested by the City Club Report of 1948. Among those involved, he said, were Al Winter, Stan Terry, James Elkins and Tom Johnson. This was further substantiated in the author's interviews with former District Attorney William Langley (Langley-Uris interview 1980) and others. 
This alleged syndicate also included Milt Hyatt who became involved by the start of World War II. Police Chief of Detectives Jack Keegan and his assistant, Tip Schulpus, allegedly represented the police department. Fred and Jim Elkins were at this time involved only with prostitution (anon.-Uris interview 1979; Lee-Uris telephone interview 1980).

Allegedly, Winter, Hyatt and Barney Morris later moved on to Las Vegas and Sam Rubin took over operation of the Pago Pago Club, previously run by Winter, where book was made on sporting events and a racing wire was set up. Fred Elkins handled prostitution. When Fred Elkins joined the group in Nevada, his brother Jim took over the Turf Club for him and tightened control, using the police department and others as his enforcers (anon.-Uris interview 1979; Lee-Uris interview 1980; anon. records of the Attorney General, Oregon State Archives accession number 61-67). Elkins also forced slot and pinball operators to give him a cut. Tom Johnson and Swede Ferguson were said to have specific ties with certain ethnic communities. Together, all these men allegedly operated a well-ordered empire with the cooperation and mutual benefit of the police, real estate management firms, banking and legitimate businesses. A well-ordered and gentlemanly operation.

One consequence of Dorothy Lee's mayorship (1949-1951) was a collapse of some of the old arrangements. She installed Donald MacNamara as police chief after a short time. The police department allegedly broke into three rival factions under Jim Purcell, Captain Carl Shoemaker and Captain Bill Brown. Brown's protection was extended to Ide (Pasha) Hasson, who opened a gambling spot on Broadway and Salmon known as Pasha's. Sources alleged that further protection came from Judge Eugene Oppenheimer and Charlie Raymond of the district attorney's office 
(anonymous report, Attorney General's files, Oregon State Archives, accession number 61-67; Lee-Uris telephone interview 1980; anon.-Uris interview 1979).

To what degree was there really a syndicate? Various sources, including informants in the black community and material in the Attorney General's Vice Investigation files in the Oregon State Archives, indicate that from some time in the mid-1930's well into the $1950^{\circ} \mathrm{s}$, a syndicate or cooperative coordination of vice activity existed in Portland. These sources insisted that the main syndicate survived through the regimes of Mayors Carson, Riley, Lee, Peterson and Schrunk. It must be emphasized that by their very nature these sources cannot be considered adequate proof of the existence of a vice syndicate. However, the consistency of these stories and their repeated appearance make them worth noting. In no sense, then, is an assertion being made that such a syndicate did exist or that those named as part of the alleged syndicate in the interviews and archival materials were in fact involved in wrongful acts.

The notion of a single syndicate's operation and its cozy involvement with Portland took root strongly in the public consciousness of Oregonians at this time, however. This concept of a single syndicate operating in collusion with police and others would become a significant factor in the vice probe of the late $1950^{\circ} \mathrm{s}$.

This dissertation also cannot assert with any accuracy that there was a formalized division of the city of Portland in terms of vice activity. What is known is that vice activity tended to be segregated by race. Specific ethnic communities seemed to have certain individuals who were both leaders of their communities in the proper sense, and also 
leaders of the vice community. The card games, horse parlors, etc., were often used by important members of the general business community. These people knew each other socially and were political contributors and supporters of specifical political candidates (anon.-Uris interviews 1979 and 1980).

Dorothy Lee's cleanup efforts changed Portland's reputation and altered its self-image. Rather than a vice-ridden city, Portland presented a closed, more conservative front. John Gunther's (1947) negative labeling of Portland may have been a significant factor in giving the city a black eye and causing it to begin to pay attention to its vice problems. Negative national publicity also played a major role in the 1956 probe as will be shown later.

Other events of interest taking place during the reforms of Mayor Lee included the opening of the first legally allowed black club with the tacit and/or direct approval of both the syndicate and the legitimate business community. All previous clubs for black people were illegal, and thus could be closed and easily controlled without due process by the authorities (anon.-Uris interview 1980).

Lee failed to gain the support of the dominant real estate, retail and business interests. She had a poor press image. Not a popular mayor, she failed her reelection attempt in 1952, losing to Fred Peterson, a druggist and city councilman.

Vice Survives.

In the years after Lee's cleanup efforts, the visible involvement of the so-called overseeing vice figures named in the 1948 report decreased but did not disappear. In 1955, according to informants' reports to the 
Attorney General (Oregon State Archives), a number of whorehouses, horse parlors and bootleg joints were opened (Oregonian, August 3, 1953).

There was prostitution through call houses in which, as distinguished from bawdy houses, the women are contacted first by phone and make specific dates with clients. Bawdy houses are locations where a client makes contact with a prostitute without any prior arrangement or references. The significance of references in the call house operation is that it tends to keep the neighborhood location quiet and the operation orderly.

Gambling took place in clubs like Duncan's and the Desert Room, in upper-class clubs and outside Multnomah County in places like the Fireside in Clackamas County. In addition, Tom Johnson operated a number of after-hours joints and gambling dens in the so-called "colored" section of the city, in areas which are now the Memorial Coliseum and Albina. Other gamblers, horse parlor operators and after-hours liquor dealers were bankrolled. Their operations existed sporadically throughout the town, particularly in the older parts of downtown close to the river, in north Portland and in southeast Portland. Men like Swede Ferguson, James Elkins and others maintained operations which would periodically be closed, usually with prior warnings from the police department. They would then reopen a short time later, either in the same location or another.

Abatements (padlocking) were rare. As shall be detailed later in this study, there is indication that the Portland Police Department had within its ranks patrolmen and command-level officers who tolerated, cooperated with and were financially rewarded by vice operators in the city. Such cooperation was rationalized in terms of the control of crime and criminals offered by such tolerance. 
More important perhaps, were large slot machine operations and bigger still, of pinball machines by men like Stan Terry, Lou Dunis, the Nemer brothers, James Elkins and others. Coin machines were the largest source of gambling revenue in Portland (Reiter-Uris interview 1980; U.S. Senate Committee Hearings 1957). These groups eventually united as the Coin Machine Men of Oregon, a group of 23 operators. Still later, they brought in the Teamsters Union in a Teamsters organizing drive which was to become a major subject of the vice controversy. The Coin Men attempted, through various means, to legitimize and maintain their businesses in the face of growing political opposition within city government. It is within the context of attempts to keep pinball operations legal that much of the vice probe took place.

The following is a list of the principals in the Portland vice probe of 1954-1958. It will aid the reader to follow the events presented in the rest of this chapter.

Altschuler, Morrie; bookmaker brought to Portland by Joseph McLaughlin.

Amundson, Lowe11; policeman allegedly witnessed 8212 Club bribe.

Archer, Bob; operator of the Rialto Billiard Parlor.

Baker, Doug; reporter, Oregon Journal.

Beckman, Les; Portland pinball operator.

Bennett, Clifford 0. (Jimny); Portland bootlegger.

Brewster, Frank W.,; president of the Western Conference of Teamsters, Seattle.

Clark, Raymond F.; Elkins' employee who tape recorded the King Towers conspiracy.

Colacurcio, Frank; Seattle restaurant operator. Maloney fled to his home. 
Crisp, It. Carl; Portland police officer.

Crosby, Clyde C.; international organizer for the Teamsters in Oregon, member of Portland's Exposition-Receration Commission.

Crouch, Neill; operator of the Mount Hood Cafe, Portland.

DeGraw, Clyde; operator of the Dekum Tavern, Portland.

Dunis, Lou; Portland pinball and vending machine operator.

Earl, Stanley; Portland city commissioner, accused of ties with Elkins, major author of City Club Report on Vice 1948.

Elkins, Fred; brother and occasional business partner of James B. Elkins.

Elkins, James B.; financier of illegal gambling, bootlegging and prostitution operations, Portland.

Ferguson, Harvey (Swede); Portland bootlegger.

Goldbaum, Hy; gambler and friend of Frank Brewster.

Gurdane, Vayne; family friend of William Langley and commandlevel officer Oregon State Police.

Hanzen, Henry; Portland and Salem attorney and early supporter of Langley for district attorney.

Hardy, Helen; Portland bawdy house madam.

Hildreth, Lloyd; secretary, Portland Local 223, Teamsters Union.

Howlett, Oscar; assistant Multnomah County District Attorney.

Jenkins, James Q.; employee of James Elkins.

Johnson, Thomas; leader of the Portland black district underworld.

Kane, Bernie; employee of James Elkins.

Kaplan, Arthur; presented evidence to grand jury from attorney general's staff.

Kell, Raymond; attorney, major supporter of Terry Schrunk. 
Kelley, John W. (Bill); Portland real estate dealer.

Lambert, William; reporter, the Oregonian.

Langley, William M.; district attorney, Multnomah County.

Malloy, Frank; business agent, Portland Local 223, Teamsters Union.

Maloney, Thomas Emmett; Seattle gambler, associate of the Teamsters leadership.

McLaughlin, Joseph Patrick (alias McKinley); Seattle gambler, alleged associate of Teamsters leadership.

McCourt, John B.; District attorney defeated by William Langley.

Minielly, George; led sheriff's raid on Ray Clark home.

Nemer, Norman; Portland punchboard operator.

O'Donnell, John J.; Multnomah County auditor and Teamsterbacked candidate against Earl for city commissioner.

Peterson, Fred L.; former Portland mayor.

Plotkin, Leo; bootlegger and associate of Thomas Maloney. "The Spy" for Langley.

Plummer, Herman; Portland real estate dealer.

Purcell, Bard; Portland police lieutenant, brother of the exchief.

Purcell, Jim, Jr.; Portland police chief under Mayor Fred Peterson.

Schrunk, Terry; Ex-sheriff and mayor of Portland who defeated Peterson.

Sellinas, Sam; Seattle associate of Teamsters.

Sloniger, C.R.; Portland attorney.

Smalley, Helen; Portland bawdy house madam.

Sutter, Richard; policeman, allegedly witnessed 8212 Club bribe.

Sweeney, John J.; Crosby's predecessor in Oregon and later Secretary-Treasurer of the Western Conference of Teamsters. 
Terry, Stanley G.; Portland pinball operator.

Thompson, Ann; bawdy house madam, Seattle and Tacoma.

Thornton, Robert Y.; Oregon's attorney general.

Tiedemann, Merlin; policeman, allegedly witnessed 8212 Club bribe.

Turner, Wallace; reporter, the Oregonian.

Walters, Herman; business associate of Budge Wright.

Williams, Brad; reporter, Oregon Journal.

Winter, Alfred; alleged syndicate figure.

Wright, Veral P. (Budge); Portland pinball operator.

Wyckoff, Ralph; presented evidence to grand jury, attorney general's office.

Zusman, Nate; operator of Desert Room, Portland nightclub.

The Exposition-Recreation Center Deal - 1954-1956.

The first event allegedly linking Teamster officials and James B. Elkins begins with the passage of an $\$ 8$ million bond measure on May 21 , 1954, calling for the building of an Exposition and Recreation Center, today known as the Memorial Coliseum.

The location of the center was unspecified. The bond measure called for an Exposition and Recreation (E-R) Commission which was to design, locate and operate this facility. Appointments were made to the Commission on June 15, 1954, by Mayor Fred Peterson. On July 3, 1954, its first meeting took place. The chairman was James Polhemus and the commissioners were Carvel Linden, James Richardson, John Carson and Clyde Crosby. Crosby was appointed to the Commission as labor's representative. All the others represented various aspects of large and small business interests, real estate and banking within Portland. 
Clyde Crosby, as the International Organizer for the state, was the highest ranking Teamster in Oregon. The various Teamster Union locals in Oregon were then under the control of the International through a trusteeship and could not elect their own officers.

When Clyde Crosby was appointed to the Exposition-Recreation Commission, an opportunity for personal financial gain on the part of any member of that Commission existed. In later testimony before the U.S. Senate Select Committee on Improper Activities in the Labor or Management Field (1957) and in the Oregonian (April 20, 1956), it would be alleged that Crosby, through special knowledge, was able to aid his cohorts, Tom Maloney and Joseph McLaughlin, together with James Elkins and Tom Johnson, in a scheme to make money through the purchase of land options on the site that Crosby would help select. Crosby would later deny these allegations and be exonerated in court.

According to the U.S. Senate Comittee Hearings (1957), there were 41 options purchased through Thomas Johnson with the involvement of Joseph McLaughlin, one of the owners of the Battersby and Smith Cardrooms in Seattle, and a close associate of Thomas Maloney and various members of the Teamsters Union leadership, particularly Frank Brewster. According to the minutes of an Exposition and Recreation Commission meeting on October 5, 1955, Commissioner Crosby proposed that the Steel-Broadway Bridge site be chosen for the Exposition-Recreation Center.

Yet his justification of the location of the central site on the east side made sense. Crosby pointed out that the Stanford Research Institute in studies specifically commissioned by the Commission had recommended no downtown site for the E-R Center. Crosby indicated that for months he had been trying to convince the E-R Commission that the 
Broadway-Steel Bridge site was the best and most desirable site for the Memorial Coliseum (U.S. Senate Committee Hearings 1957. Note: The U.S. Senate Select Committee on Improper Activities in the Labor or Management Field 1957 will hereafter be abbreviated to U.S. Senate Committee Hearings 1957).

In the U.S. Senate Comittee Hearings (1957) an affidavit described how, in the last part of January or the first part of February 1955, James Elkins asked realtor John William Kelley to examine some houses on which he was considering options. These were located in the Williams Avenue area near the Broadway and Steel Bridges (U.S. Senate Committee Hearings 1957). According to Kelley, by March of 1955, Elkins, Kelley and Tom Johnson of the Keystone Investment Company, had gathered with Herman Plummer, a black realtor, to examine property options being purchased in the Williams Avenue area.

Elkins told Kelley that he had an "in." By June of 1955 Elkins and Joe McLuaghlin, a Seattle gambler, had met in Kelley's office to draw up a contract on the assignment of certain options to be purchased in the Stee1-Broadway Bridge area.

During the conversations between McLaughlin and Elkins, according to Kelley, Clyde Crosby's name was mentioned on six occasions. McLaughlin, in the presence of Kelley, supposedly called a man named Crosby and made reference to Clyde in the phone conversation. On the basis of this evidence given to the U.S. Senate Committee investigators and read into the minutes of the U.S. Senate Committee Hearings, there is indication that Crosby was at least conversant with the plan of these men to make money on the E-R Center location (U.S. Senate Committee Hearings, 1957). 
It is interesting to note that as Crosby fought what he thought was a losing battle to locate the E-R Center at the Broadway-Steel Bridge site, the options were one by one sold off. The only man to eventually make a profit from the options was Tom Johnson, the original black partner and long-time land owner in the particular area involved.

Later evidence presented to the U.S. Senate Committee Hearings (1957) indicated that the initial attempt to organize a profit-making venture around options and advance knowledge concerning the location of the E-R Center was not well received by the various partners involved. The plan, which apparently was initiated independently of the Teamsters leadership, did not materialize until Frank Brewster discovered it and decided to go ahead in supporting it (U.S. Senate Committee Hearings, 1957)

The final decision on an east side versus west side location for the E-R Center involved a voter advisory election in the May 1956 primary, the same election that saw pinball outlawed. The west side site lost. At the time that the site selection issue was before both the public and the Commission, a large retail and business center was being planned on the east side close by the eventual location of the E-R Center. This complex, the Lloyd Center, involved large property holdings on the edges of what was known as Sullivan's Gulch, reaching all the way down to Union Avenue, close by the river, and nearly to the E-R site selected. The Broadway-Steel Bridge site now holds the Memorial Coliseum.

Whatever Crosby's interests may have been in the selection of an E-R site at that location, there is ample evidence that others, not particularly associated with the Teamsters Union, ranging from Tom Johnson to the enormously powerful Lloyd croporation, had particular interests in creating a center at that location. 
James Elkins - the Man Who Talked

As will be shown later, much of what we know about the alleged conspiracies connected with this vice probe came from a source of not particularly good reputation. The man who began the exposes was James B. Elkins. Elkins, an admitted vice figure, was a convicted felon who had shot it out with the police in Arizona. In addition, he had been convicted of a narcotics charge. Elkins used wiretaps and hidden tape recorders to gain support for his allegations, allegations which were later challenged. Many suggestions were made that Elkins had manipulated tapes and wire recordings for use as blackmail devices against District Attorney William Langley. Elkins, moreover, had much to gain by convincing the public that he was a much-maligned and harmed individual facing overwhelming odds in his fight against an attempted takeover by outside gangster elements, with ties to the Teamsters Union.

Elkins' story was accepted by the Oregonian in a series of welldocumented and exciting articles beginning in April, 1956, by William Lambert and Hallace Turner. These two would go on to win a Pulitzer Prize for this vice expose. Their version of the vice problem in Portland would become the nationally accepted version when it was retold at the U.S. Senate Committee Hearings (1957).

In retrospect it may seem strange that the Oregonian and later the U.S. Senate Committee (1957) would accept with so little critical investigation the word of a man of Elkins' reputation. Yet this acceptance makes sense in terms of the interests of both. In terms of local Republican interests, it can be seen as a response to the rise of the Democratic party in Portland. This switch must have been perceived as a threat by the Republican Oregonian in its desire for a continued 
place in the hegemony of its traditional interests which included a traditional anti-union bias. The Senate investigation, like the Oregonian, had a vested interest in lessening the power potential of organized labor.

It may be in this context that the Oregonian saw the rise of William Langley and Terry Schrunk as inherently sinister. Fred Peterson, the man who lost the mayoralty to Terry Schrunk in a nominally nonpartisan race, was a Republican and was supported by the Oregonian. In contrast, the Oregon Journal, an independent Democratic paper, would make a determined case that the Oregonian was ignoring real corruption and collusion between James Elkins and members of the Portland Police Department, including Chief of Police James Purcell and Mayor Fred Peterson. The Journal took a position critical of the way in which Lambert and Turner proceeded in their investigation. They believed Elkins to be a liar.

It is doubtful there shall ever be a clear and definitive statement of who was telling the truth and who was lying. There are no doubt elements of truth and falsehood in all parties' accounts. Each and every witness, both in the U.S. Senate Committee Hearings (1957) and in the reporting of the Oregonian and the Journal, had much to gain by a convincing presentation of his own version of the vice situation in Portland.

Two Papers, Two Views

Some background on the Oregonian and the Oregon Journal will shed some light on the reasons for their divergent views. Both were old family-owned newspapers. Ironically, E.B. MacNaughton, the same man who took such an active role in guiding the life of the black community 
during the war years and who was president of the First National Bank by 1942, was publisher of the Oregonian. In 1949-1950 he authorized the sale of the Oregonian Publishing Company (MacColl 1979) to the Newhouse newspaper chain. By 1956 the Oregonian's financial and political ties to the local political structure were weaker than those of the Journal.

The Journal was locally owned as an independent paper in the control of the Jacksons, an old-line Portland family. It was far more centered in local politics and interests. The Journal stayed in local hands through the 1950's, when it too went to the Newhouse chain after an ugly strike in which labor was defeated at both papers.

The Oregonian, Republican slanted, though editorially independent of its owners in New York, nevertheless had both the advantage and the disadvantage of having its financial base and control resting in the hands of parties a continent away.

The two daily papers, as independent and highly competitive enterprises, not only took differing positions on the vice situation, their reporters became bitter opponents. In an interview 23 years later, William Lambert, ex-Oregonian reporter, now with the Philadelphia Enquirer, had this to say about the papers' rivalry:

...the Journal deliberately set out to destory the story. Now, how do I know this? I can tell you some of the things they did. I know, for example they went to the extent of printing up a broadsheet with some of these inflammatory editorials about "Big Jim Elkins, the vice king and the narcotics user" and how he was trying to destroy all these decent, honorable people.

They instructed their carriers to put that in every Oregonian box. Now, we've got affidavits. We had an enormous amount of material to support this...Our circulation people got this information. They interviewed Journal carriers who were told what to do with these damn broadsheets.

They deliberately, they distorted stories like I've never seen since in a daily newspaper... They just set out to do a hatchet 
job, and the only way you could ever really understand this is through a thorough analysis of what was done in both papers item by item. Then you can see the pattern. It is so clear that it's shocking. Lambert-Unis interview, 1979).

There is little question that the intense and unpleasant rivalry between the two papers served to bring much more information to the public. Today, because both papers share the same ownership, the wildly divergent views and bitter rivalry probably could not happen.

Robert Y. Thornton, at the time of the vice probe an up and coming State Attorney General, had a different view of the role of both papers in the probe. Thornton emphasized that the police must have known long before the story broke that there was a busy vice scene in Portland. But it was the publication of the story that forced action on the part of the authorities (Thornton-Uris interview, 1980).

Thornton indicated he was pressured and dismayed by both papers' conduct:

One of the fascinating aspects of the whole thing was the bitter, spiteful duel between the two newspapers. I think that's a very discreditable chapter in the history of Oregon journalism.

The first thing that the Journal did was just deliberately set out to wreck the Oregonian's expose. They just conducted a torpedo attack on everything that the Oregonian was claiming. Their reporters came into the grand jury room and interviewed grand jurors. They had no right to be in there at all, but the court didn't do anything about it. I thought that was outrageous.

...I think for the first two or three days they didn't say anything after the expose started; then they started this business of doing everything they could to combat the Oregonian's expose. The unfortunate part of it was that it just impeded the investigation something terrific.

... and then the Oregonian tried to pressure me. Well, after... the first time the Terry Schrunk matter was put before the grand jury I put it before, and they complained that Schrunk wasn't indicted, and so I let Bob Davis present it this (second) time to the grand jury, and the grand jury did not 
indict, and then they again tried to pressure me into putting it before them the third time, and I wouldn't do it, and they sent the word down that if I didn't, there was going to be a real hatchet job on me, and they did it (Thornton-Uris interview, 1980).

Eventually, as will be detailed later, the grand jury did indict Schrunk. It is hard not to see traditional political party rivalries and loyalties as a part of the above-mentioned pressure. Schrunk and Thornton were Democrats. The Oregonian and the man they supported for mayor in 1956, Fred Peterson, were Republican.

Doug Baker, of the Journal, in reflecting upon the journalistic ethics of the time, substantiates William Lambert's characterization of Journal reporter, Brad Williams, as a cynical character like Hildy Johnson out of the play The Front Page (Lambert-Uris interview, 1979; Baker-Uris interview, 1980).

\section{The Teamsters Move In}

In 1954, according to an April 22, 1956 Oregonian article by Turner and Lambert, the Teamsters leadership had decided to organize and dominate the pinball business. According to this article the refusal of City Councilman Stanley Earl to support pinball operations in Portland made Earl an enemy of Clyde Crosby. In a Central Labor Council meeting over political endorsements during the week of April 15, 1956, 50 members of the Teamsters Union allegedly packed the meeting and forced a 70 to 62 majority vote favoring the endorsement of John J. O'Donnell for the council seat then held by Stanley Earl. Earl was a long-time labor movement figure, an officer of the International Woodworkers of America, and active in the CIO--a candidate who would have gained labor support had the Teamsters not intervened in the decision-making process (Oregonian, April 22, 1956). 
According to the Oregonian article, the Teamsters Union in Seattle had developed a specific technique to bring pinball within the control of the labor union, a technique labeled by the Oregonian as "The Seattle Plan." It involved creating first an organization of coin machine men including all pinball, jukebox and slot machine operators. This single organization would then be more amenable to Teamsters control. All employees of the Coin Machine Men would be coerced into joining the Teamsters Union. The Union could then use their control over the Coin Machine Men for a number of political and economic purposes. It would become possible, for example, to boycott taverns doing business with beer and liquor companies that were engaged in labor struggles with the Teamsters. This is but one example of how such power would be useful. The implication was made that monies would change hands in the course of organizating the Coin Machine Men.

The Oregonian (April 22, 1956) pointed out a specific example of this process. It alleged that on September 1, 1955, the Dekum Tavern on Union Avenue took delivery of a coin-operated shuffleboard from a Seattle firm, the American Shuffleboard Sales Company. At the same time, the owner of the Dekum Tavern directed William Goebel, a member of the Coin Machine Men of Oregon, to remove Goebel's machine. Shortly after that, the jukebox in the establishment, owned by a different member of the Oregon Coin Machine Men, was removed from the tavern. The tavern was now without a jukebox. It was unable to receive deliveries of food and beer because of Teamster picketing. The Dekum Tavern owner was told not to do business with Stan Terry, then on the outs with the Teamsters over his effort to keep his employees out of the Union. 
The tavern case came before a U.S. District Court judge and a temporary injunction was issued on November 1, 1955.

Accusations in other law suits, according to the article, suggested that coin machine control led to coercion through picketing and was commonplace in the Seattle area although new to Oregon. Membership in the Coin Machine Men of Oregon eventually meant membership in the Teamsters Union. With the creation of the Coin Machine Men of Oregon came formal Teamster manipulation, discipline and cooperation. Territories could be formally divided up and profits in restraint of trade could develop. If discipline was not followed, a member could be expelled, not only from the Coin Machine Men, but from the Teamsters Union as well.

In an Oregonian front page article on April 23, 1956, Turner and Lambert stated that Paul Patterson, Republican governor of Oregon, was helped by the Teamsters in his 1954 campaign. They stated that Patterson was under continual pressure from the Teamsters. In 1954 the Teamsters, through the intervention of Thomas Maloney (who, through various records, is tied to Frank Brewster, Clyde Crosby, John Sweeney and other officials of the Teamsters Union), turned Democrat William Langley's campaign for District Attorney from one in which he was virtuaily certain of defeat at the hands of incumbent Republican John B. McCourt. Through contact with laboring people and massive influxes of money and skills, Langley was elected District Attorney of Multnomah County in 1954.

The Oregonian pointed out that McCourt was supported by the Teamsters in two prior elections, but then abruptly not supported when Langley's campaign was developed around the efforts of Thomas Maloney. When Portland Teamsters head Clyde Crosby visited Mayor Fred Peterson and 
Peterson refused to fire Jim Purcell as Chief of Police, the Teamsters Union, in the person of Crosby, warned Peterson that he would be losing their support and then moved to support the opposition candidate, Multnomah County Sheriff Terry D. Schrunk, for mayor (Oregonian, April 22, 1956).

According to the April 23, 1956 Oregonian article, Fred and James Elkins, both involved in racket operations and well known as bankrollers for after-hours joints in Portland, entered Langley's campaign and agreed to pay printing bills as part of a deal involving Clyde Crosby and the Teamsters Union. According to Crosby, as cited in the article on April 23, Elkins went to the Teamsters building to ask Crosby to give the Union support to Langley. Elkins said that the Langley effort was supported by Tom Maloney, and finally Clyde Crosby made the decision to bring the support of the Teamsters Union in Oregon behind William Langley. This was after Maloney had called John Sweeney, secretarytreasurer of the Western Conference of Teamsters in Seattle.

The article alleged that $\$ 5,000$ from Union sources went to Langley's campaign. Jim Landye, a reputable attorney who represented the Teamsters Union, had heard rumors from McCourt that Teamster leaders were supporting Langley because the Union was going into the rackets. Landye doubted these rumors, according to the Oregonian story, and went to the Teamsters hall to find out. Landye told McCourt, the article continued, that he was right. Landye did not resign from McCourt's re-election committee, but refused to take an active role in the campaign since he had a conflict of interest.

The April 23 Oregonian stated that McCourt was informed that part of the reason for the Union's opposition to him was his support and 
friendship with Stan Terry, then on the outs with the Teamsters Union. Later Terry would reconcile his differences with the Union and become a leader of the Coin Machine Men of Oregon. The Oregonian further stated that as the date of the election neared, U.S. Senator Warren G. Magnuson of Washington came to Portland and made a radio speech supporting Langley. Magnuson came to be identified as an associate both of Teamsters Union leadership generally, and one of the most notorious leaders of that Union, Dave Beck, (U.S. Senate Committee Hearings, 1957). According to the April 23 Oregonian article, Thomas F. Maloney came to Portland to gain a foothold in Portland political and vice operations. Maloney was brought to Portland by James Elkins to help direct Langley's campaign. Maloney had frequent contacts with Langley, successful candidate for District Attorney, James Elkins, Clyde Crosby, John Sweeney and Joe McLaughlin of the Battersby and Smith Cardroom and Saloon in Seattle.

Langley and Elkins were partners in the late $1940^{\circ} \mathrm{s}$ in a restaurant known as the China Lantern in which gambling activities were reputed to have taken place (Oregonian, April 23, 1956). Langley, in a 1980 interview, denied the connection, saying that the relationship was on paper only, and even then only lasted a few days.

Through various airplane reservations, hotel reservations and the like, much of James Elkins' story of the meetings among Clyde Crosby, John Sweeney, Frank Brewster, Tom Maloney and himself are corroborated (Exhibits 15 though 40 of the Hearings of the Select Committee on Improper Activities in the Labor or Management Field 1957).

Given the Teamsters' effort to organize pinball, it is plausible to suggest that the Teamsters were attempting to assure that an administration friendly to the Union's involvement would be elected, one that was tolerant of pinball. 
It seems just too strong a coincidence that the Coin Machine Men of Oregon were organized at the same time or shortly after a similar organizational effort had been successfully undertaken in Seattle. Certainly the Teamsters' coffers and membership were enriched through monies gained in this organizing effort.

If the Teamsters were, as Elkins accused, attempting to move into organized vice activities in Portland, then Crosby's, Maloney's and McLaughlins' activities became more understandable. The key to comprehending all of this rests with the tape recordings made secretly by James Elkins of both telephone and room conversations of Maloney, Mclaughlin, Langley and others. It was these conversations that formed the crux of the James Elkins case, and the basis upon which Elkins argued that the Teamsters Union was attempting to move in on his activities, as will be shown later.

While the Elkins recordings do show elements of conspiracy among the above-mentioned parties, there is no proof that the Teamsters leadership itself was aware of these activities or was actively encouraging them. Rather, the recordings show frequent references to "John" and "Frank" in Seattle as men to check with. Corroborative evidence creates the clear implication of Teamsters Union involvement in the Portland rackets. As will be shown, the manipulations of power figures on the local level constitutes a strong indication of the Western Conference of Teamsters' interest in the local racket scene.

Horace Crouch, owner of the Mt. Hood Cafe, described the picketing of his property. Teamster pickets, organized by Teamsters representative Frank Malloy, later were described by Clyde Crosby as an "advertising picket." When Malloy was approached by Crouch as to why he 
was being picketed, Crouch was told that he had to pull Stan Terry's pinball machines from his property in order to continue operation. This was during the period of time when, according to testimony, Stan Terry was engaged in a struggle with the Teamsters Union to allow only himself and not his employees into the Union (U.S. Senate Committee Hearings, 1957). Terry eventually lost and returned to the Teamsters Union.

Three months after the picketing of Crouch's Mt. Hood Cafe, he was allowed to have Terry's machines in his shop because Terry had capitulated to the Union. This was denied by Terry (U.S. Senate Committee Hearings 1957). Crosby's explanation of this incident includes the denial that the Teamsters had ever attempted to keep people out of the industry or to control the coin machine industry in any way (U.S. Senate Committee Hearings, 1957). He denied any knowledge of fair trade agreements and stated that the only contracts that existed were standard union contracts.

Crosby indicated that the only thing he understood about the picketing at the Mt. Hood Cafe was that there was a dispute with the American Suffleboard Company over a contract. Local 223 Teamster Secretary, Lloyd Hildreth, who later denied the allegations of improper picketing, indicated that the American Shuffleboard Company, which was servicing the cafe, attempted to have a different contact than other coin machine men had, and that the picketing was an effort to force American into signing the same standard, industry-wide contract which American did sign (U.S. Senate Committee Hearings, 1957). 
A View From a Distance - The State Capitol

No more clear a history of the vice probe exists than the transcription taped by then Attorney General Robert Y. Thornton on June 4, 1959. Like all histories and particularly those drawn up by history's principals themselves, it is limited in perspective. In this case, because of the position he held as grand jury inquisitor and chief investigator for the state, and as a politician forced by circumstance and the ambitions of others into an impossible role, Thornton reflects the bitterness of a man burned by a fire set by others. In spite of this, there is little question of his fundamental honesty or accuracy in recalling events then less than six years old.

Thornton began his account by relating a scandal in the Oregon Liquor Control Commission (OLCC) in the fall of 1953. An investigation, conducted at the suggestion of Republican Governor Paul Patterson by Robert McGuire of the law firm of McGuire, Shields, Morrison and Bailey, centered on an alleged $\$ 10,000$ bribe offer made by head of oLCC Investigation-Undercover Division, Thomas Sheridan (Thornton, Oregon State Archives 1959).

During the reign of Mayor Fred Peterson (1952-1956), after-hours bootleg and gambling establishments flourished in Portland with little action from either the Portland police or the OLCC enforcement people. The Attorney General's office became aware of more than mere tolerance of liquor violations. Gifts ranging from cases of liquor to trips to the Kentucky Derby were reportedly accepted by OLCC enforcement people. The entire North Precinct of the Portland police as well as others were being paid off, reported Thornton in his history (Thornton, Oregon State Archives 1959). 
Shortly after Thomas Sheridan was suspended, Governor Patterson, who was elected with Teamsters support, was visited by Crosby, Portland Teamsters head, and was asked to reinstate Sheridan.

Thornton believed:

That there had been very definitely a criminal conspiracy, a criminal partnership involving Elkins, Maloney, McLaughlin, Langley and Crosby. And part of the hope of that criminal conspiracy was to derive revenue from the continued operation of these bootlegging-gambling joints which at the time were being bankrolled by James Elkins (Thornton, Oregon State Archives 1959).

When Thornton found that he could not obtain the depositions taken by McGuire during his investigation, he announced that he would conduct his own investigation using ex-FBI agent, LeRoy Scousen.

When Democrat William Langley, with Thomas Maloney's and Teamsters' help, was elected Multnomah County District Attorney in the fall of 1954, Thornton attempted to persuade Langley to use the Grand Jury to investigate the liquor matter which he believed Governor Patterson was "sweeping under the rug."

Before taking office, Langley promised to investigate. But once in power, he delayed acting until suddenly, in September of 1955, he announced that he would call the Grand Jury into action. The Grand Jury met and the result was, in Thornton's words, "a whitewash." (Thornton, Oregon State Archives 1959)

Yet there was another result. In a press conference following the Grand Jury meeting, ex-Portland policeman Bartholomew, employed by Scousen, accused Thornton of using the investigation to "...raise a political stink." (Thornton, Oregon State Archives 1959.)

Thornton apparently suffered as a result of the editorial wrath of both the Oregonian and the Oregon Journal. Thornton would remain caught on the horns of the press for the whole of the probe. 
There are some purely circumstantial indications that Thornton may have been spiked in his investigative efforts by the so-called King Towers conspirators, Elkins, Maloney, Crosby, McLaughlin and Langley. Tapes found in the archives of the State of Oregon appearing to be part of the ciandestine tapes made by Ray Clark at James Elkins' orders, show a definite pattern of attempted manipulation of major political figures.

The frequent use of pressure and intimidation or the threat of it, without any subtlety or concern for existing unspoken and quite traditional arrangements, would prove the undoing of the King Towers plotters. The style of action more than the actions themselves would turn Portland's elites off as nothing else could or would. Such anger at upsetting the gentlemen's agreements in the city's political, economic and recreational life would extend as well to the efforts of the Senate Select Committee on Improper Activities in the Labor or Management Field (1957).

Thornton saw a pattern of payoffs to the highest levels of the police department by madams like Jerry Rogers and by cardroom operators like Andros of the Dahle and Penne cardroom. Thornton saw these payoffs as channeled through Elkins and Tom Johnson. He listed after-hours, bootleg, gambling and whorehouse operations, some within a half-block of the police station as: the Three Deuces, the Keystone, the Main Stem, the Red Front, the Explorers Club, the New Western Hotel, the Perry Rooms, Tiny's Place and the Market Club, as well as seven Pan games and two Chinese gambling operations. He believed that all elements of the Oregon law enforcement community were aware of the Portland situation (Thornton, Oregon State Archives 1959). 
The pattern of denial and averted official eyes persisted even after the Oregonian played the Elkins tapes of the King Towers conspiracy for Governor Elmo Smith's assistant, Ed Armstrong, State Police Superintendent, Fod Maison, and State Police Captain Vayne Gurdain, a family friend of the Langleys.

It was not until the Oregonian broke the story on April 19, 1956 that any official response was forthcoming. Later, in a characteristic attack upon the Oregonian, the Journal would rhetorically ask why the Oregonian had not gone to the authorities if their tale were true. The answer was simple. They had, and had been rebuffed (Thornton, Oregon State Archives).

Governor Elmo Smith asked the State Police to investigate conditions in Portland. At that point Langley invited Thornton to assist. Thornton refused, not wishing to be caught powerless in a complex and dangerous situation. Finally, Governor Smith did as Attorney General Thornton wished. He ordered Thornton to intercede and gave him power to supercede District Attorney Langley.

According to Thornton's history, editorial page editor, Herb Lundy, managing editor Robert Notson, and the Oregonian's attorney, David Fain, urged Thornton to give their informants immunity. Otherwise the Oregonian balked at giving testimony. The 1955 anti-wiretap law could put the listeners, as well as the initiators of such materials, in jail. The Oregonian wanted to protect their informer, Jim Elkins and their staff. After tense discussions with Governor Smith and his staff, the immunity requested was denied. Thornton dated his troubles with the Oregonian from that time (Thornton, Oregon State Archives 1959). 
With Assistant State Attorney Francis Wade, Thornton continued his investigation, planning to use the June Grand Jury for presentation, but Langley and his staff were using the May Grand Jury to present Langley's version of the vice problem. Langley barred Thornton from access to the Grand Jury. Thornton sought and received a court order to stop Langley, but not before Judge Dobson had to order the Sheriff's office to break into the Grand Jury room. Langley maintained then and maintains now that he saw a conspiracy by Jim Elkins and others (including possibly the Mayor and Chief of Police) to discredit him while he, as District Attorney, was trying to stop a corrupt system in its tracks (Langley-Uris interview 1980).

While the Oregonian agreed not to publish Grand Jury witnesses' names, publisher William Knight and editor Arden Pangborn of the Journal would not agree. They were convinced that any investigation that did not result in toppling Elkins, Clark and anyone else involved with them, including the Mayor, was inadequate.

In his history, Thornton indicated that the Journal offered electoral support for him if he would conduct the investigation the way they wanted - including firing Francis Wade and hiring Robert Davis. In the end, both men were used by Attorney General Thornton (Thornton, Oregon State Archives 1959).

The Journal was not the only agency to pressure Thornton. The State Police wanted the entire matter placed in their hands, and even went so far as to use Thornton's brother-in-law as a go-between to persuade Thornton. Brad Williams, Thornton said, spread rumors of bribes by Elkins to Thornton, a charge both Thornton and Elkins denied (Thornton, Oregon State Archives 1959). 
It was with horror and a dawning sense of doom that Thornton discovered that much of the Oregonian's famed Elkins tapes were unintelligible to the average listener. (After hours of listening over and over to the surviving archival tape copies, the author can state that less than a fifth of the material is fully comprehensible today.) Thornton faced a nightmare. Witnesses were scared. Some had disappeared. Reporters wormed their way in everywhere, even into the Grand Jury waiting room. It was a circus. With the tapes as a grand finale, it was certain to be a terrible flop (Thornton, Oregon State Archives 1959).

Still Thornton persisted as best he could. He divided the matter into seven areas:

(1) The King Tower conspiracy;

(2) The E-R land grab;

(3) The pinball-Teamsters cases;

(4) The bootleg and gambling spots;

(5) The call girl operation;

(6) The payoff system with the Portland police; and,

(7) Whatever was left or appeared uncategorizable (Thornton, Oregon State Archives 1959).

District Attorney Langley was not through yet, however. Elkins and his associates were hit with many other charges, tending to both quiet them and limit their credibility.

The Journal was, from Thornton's point of view, ruthless and unfair to him and to the investigation. On July 23, the Journal ran Langley's own version of events. This Thornton saw as a way for Langley to reach the public without ever testifying before the Grand Jury. 
While Bob Davis was presenting the police payoff material to the Grand Jury, an Elkins employee unexpectedly fingered Terry Schrunk as a bribe recipient. Schrunk offered to take a lie detector test, which he failed. Nevertheless, Thornton felt the case against Schrunk was weak at best.

The Oregonian pushed for Schrunk's indictment and eventually, after the matter was presented four times to the Grand Jury, he was indicted. He would later be exonerated as witnesses against him were impeached or changed their stories. Thornton saw the failure of the Schrunk case, tried early on as it was, as the end of public confidence in the whole investigation (Thornton, Oregon State Archives 1959).

Thornton faced a long list of witnesses and growing criticism of the cost of the investigation. Public officials were invited rather than subpoenaed to testify. Multnomah County District Attorney William Langley was quite willing to talk outside the courthouse, but refused to appear voluntarily before the Grand Jury. He was not subpoenaed as it was feared that he might escape prosecution through the immunity process.

McLaughlin, found by the Journal along with Maloney, was offered up like a piece of cake at the tail end of the Jury hearings. Again, fearing the immunity issue, Thornton did not use either man. Doug Baker of the Journal interviewed Thornton with a concealed microphone and, according to Thornton, printed a distorted version of the interview (Thornton, Oregon State Archives 1959). Indictments were often drawn up in error. Jurors were contaminated in at least one case and a new jury was needed before indictments could be presented.

According to Thornton, his assistant, Arthur Kaplan, was brought in for his experience in the pinball enforcement area. While presenting to 
the January Grand Jury, Kaplan, with the assistance of Ralph Wyckoff, led what came to be called "the run-away Grand Jury" which produced 59 new indictments and a Grand Jury report accusing nearly everyone, including the Attorney General, of a massive cover-up of extensive corruption (Thornton, Oregon State Archives 1959). In 1979 Kaplan indicated that he still felt that Portland was a hotbed of organized crime underneath its placid exterior (Kaplin-Uris interivew 1979).

As a punishment suited to the crime, Thornton ordered Kaplan and Wyckoff to prosecute the cases they had indicted. Kaplan, meanwhile, was in contact with Robert Kennedy of the U.S. Senate Select Committee on Improper Activites in the Labor or Management Field (1957). Eventually he escaped to a staff position on the Committee. At one point, Thornton believed he was sent to Washington by Kennedy solely to give Kaplan a free reign with the Grand Jury (Thornton, Oregon State Archives 1959).

Langley met with Thornton, against the latter's better judgment, and, according to Thornton, in the course of a rambling discourse in front of three others, Langley accused him of taking a bribe, an accusation he failed to deny. Thornton stated that Brad Williams used the failure to deny as support for an accusation in the Journal (Thornton, Oregon State Archives 1959).

In the final analysis, Attorney General Robert Y. Thornton faced an impossible task. He took over an investigation that was compromised at all levels. Witnesses were unreliable or absent. The tapes upon which Elkins' story hung were unintelligible without an interpretor. Not surprisingly, in terms of successful prosecutions the results were minimal. 
The View From the Grand Jury

Examination of the report of the March 1957 Grand Jury, the socalled run-away Grand Jury presided over by Wyckoff and Kaplan, reveals a very reasoned argument for the failure of the vice probes.

They began by pointing out that records and evidence kept by both the Sheriff's office and the police department were poorly maintained and controlled, which made concealment of crime easy. Evidence was hard to retrieve and in many cases lost.

The Grand Jury found that officials used their status and power as well as public monies to avoid scrutiny. Langley's action in continuing to indict key witnesses for crimes that would silence their testimony, and pressure through the police department by then Mayor Terry Schrunk to silence witnesses against Schrunk, are two examples the Grand Jury cited (Grand Jury Report, Oregon State Archives 1957).

The Jury noted that many of Elkins' loudest accusers were those who in years past could have done something about Elkins' activities but did not. Two investigators on the District Attorney's staff and a police detective were assigned full time to aid in vice investigations (Grand Jury Report, Oregon State Archives 1957).

The Grand Jury went on to accuse the former Sheriff and District Attorney, among others in the city and county government, of knowing Elkins and having business dealings with him. They suggested that these officials were compromised by business and campaign tie-ins and were thus unable or unwilling to act against the crime network.

The Grand Jury turned upon Attorney General Thornton and accused him of failing to carry out the Governor's order to investigate the situation in Portland with adequate vigor, competence and effectiveness. The Grand 
Jury agreed that the Teamsters were using their power to control vice in Portland, but were very critical of Thornton's handling of the probe.

The Grand Jury believed Thornton was reluctant to prosecute all involved. Thornton refused to act against popular figures and appeared to discourage indictments in several instances. The fact that the state would appropriate only $\$ 300$ to investigate and indict Langley and Schrunk was typical of the lack of money and staff time spent on the investigation.

Thornton failed, the report said, to assign adequate legal staff to the case. He allowed witnesses to be harrassed and did not adequately supervise the Grand Jury. He allowed evidence to be lost or contaminated. Thornton did not follow up on acts of contempt of court. He failed to coordinate the overall investigative effort. As an example, the Jury cited Thornton's alleged failure to meet with the investigating attorneys and staff to plan an overall effort. The Grand Jury said he ignored evidence of crime and discouraged the hearing of evidence (Grand Jury Report, Oregon State Archives 1957).

The U.S. Senate Select Committee on Improper Activities in the Labor or Management Field Takes on Portland

While the vice probe version presented at the U.S. Senate Committee Hearings (1957) serves as a convenient device for organizing the Portland events along the lines of the most dominant view at the time on the national level, it is nevertheless an incomplete view. The U.S. Senate Committee Hearings' counsel was Robert Kennedy. (The Committee, was popularly known as the "McClellen Rackets Committee.") The Committee was chaired by John L. McClellen. Senators Irving Ivers, John F. Kennedy, Sam J. Irvin, Pat McNamara, Joseph R. McCarthy, Karl Mundt and Barry Goldwater were also on the Committee. 
According to an interview with Arthur Kaplan, an investigator for the Attorney General in the vice probe in Portland, and who later worked for the U.S. Senate Select Committee on Improper Activities in the Labor or Management Field, the Committee was seeking a sensational opening for its attacks on organized crime in the field of labor. He was, he indicated, instrumental in making contact with Robert Kennedy and persuading him of the importance of the Portland vice probe as a beginning of an examination of the Teamsters Union (Kaplan-Uris interview 1979).

When the U.S. Senate Committee Hearings (1957) are examined, it must be understood that this was a case carefully prepared and orchestrated by Robert Kennedy and that it was the launching of not only this particular investigation, but of the attack on alleged organized crime and on labor in general.

The U.S. Senate Committee Hearings (1957) follow a pattern set during this same period by other congressional investigations including the House Committee on Unamerican Activities. Persons called before the Committee and under indictment in Oregon were repeatedly asked questions that could serve to incriminate them. Committee members often showed a total disregard for the fundamental rights of witnesses. In an interview given in 1980 by one-time Oregon Attorney General Thornton (presently serving on the Oregon State Court of Appeals), this point was emphasized.

Turner and Lambert Testify. The Hearings began with Oregonian reporter Wallace Turner testifying as to the origins of his news stories. Turner pointed out that he knew Elkins as early as 1949 when Elkins was already part of the crime scene, and that he knew him off and on as a source for newspaper stories through October 1954; that therefore Elkins had reason to trust Turner and vice versa through all those years. Yet, 
Turner insisted that he did not associate much with Elkins until February 1956 when he began to see him to develop the vice probe stories.

Turner pointed out that the Portland City Council had, by resolution, asked the Senate to come to Portland to investigate the Teamster activity in Portland. He claimed that Elkins had been physically threatened. As a direct consequence of his involvement in attempting to bring the Teamsters' organized crime activities in Portland to light, Jim Elkins faced federal and local indictments for various criminal activities.

Turner further alleged that in the course of the investigation some of Elkins' recordings were illegally seized at the home of one of Elkins' employees, Ray Clark, at one time Chief of Police of St. Helens, Oregon and ex-Portland policeman (U.S. Senate Committee Hearings 1957).

Lambert testified that there was a conspiracy between the Teamsters Union and the Coin Machine Men of Oregon and that there was difficulty in any special Grand Jury's investigations of the matter because there was no provision in Oregon politics for special Grand Juries.

The Attorney General of Oregon could not undertake special investigations of ciminal matters without the specific direction of the Governor of the State. At the time that these investigations were taking place, the Attorney General was a Democrat and all other statewide elected officials were Republicans. William Langley, District Attorney of Multnomah County at the time, was also a Democrat and had announced that he would undertake an investigation of the allegations of James Elkins. Further complicating this was Langley's known associations with Elkins in prior business deals (the China Lantern). He had, Turner said, a direct interest in the outcome of the Grand Jury investigaion (U.S. Senate Committee Hearings 1957). 
Evidence was given that the Teamsters had tie-ins with certain principals in the investigation. Albert J. Ruhl, a Teamsters official, indicated that in 1948 Tom Maloney had requested a loan from the Union to open Maloney's Sports Center in Spokane. The loan was granted because Maloney was a friend of Frank Brewster. Ledger sheets indicate that the loan was made.

Maloney Stayed Mum. Tom Maloney took the Fifth Amendment innumerable times and refused to identify a document appearing on page 366 of the Senate investigations in which Maloney assigned certain valuables to McLaughlin, including interest in a cardroom for about $\$ 10$. Further, according to evidence developed by the Committee, Maloney visited Brewster and used Teamsters travel credit cards, according to the secretary operating out of the Teamsters Union office, and travel for Maloney and McLaughlin through various airlines was arranged through Frank Brewster's office. (This allegation is verified through documents presented, pages 366-370 of the U.S. Senate Committee Hearings 1957).

McLaughlin Does Not Talk. Joseph P. McLaughlin then testified. He indicated that he knew Frank Brewster for 20 years but declined to answer if the Teamsters ever paid any of his bills. He refused to indicate whether or not his cardroom had a Western Union ticker tape for race results and would not indicate if there was gambling going on. In general, Mclaughlin would not answer any questions about the Portland situation, citing the fact that he was under indictment in Portland (U.S. Senate Cormittee Hearings 1957).

Elkins Says Much. The next Senate witness was James Elkins, racketeer and owner of the Service Machine Company, one of the companies in the contract group known as the Coin Machine Men of Oregon. Elkins 
came to Portland in 1936. Prior to that, in 1931 in Arizona he was given 20 to 30 years for assault with intent to kill a policeman. He was pardoned after four years. (No explanation was ever made as to why this criminal figure was given a pardon in the State of Arizona.) In 1938, he was arrested in Portland when he picked up a narcotics package from a Western Union office, was convicted in federal court, and served a year and a day. Elkins indicated that his life was not always an easy one in the rackets, that, for example, in the course of picking up slot wachines, he and his brother were shot at. He testified that since 1940 he had no trouble. Then in 1956 he faced some 14 to 16 counts in Oregon alone and 9 counts in federal courts on wiretapping and other matters (U.S. Senate Committee Hearings 1957).

Elkins wanted to get his machines into the busy Labor Temple. He attempted to get into any number of unions so that his machines could have a union label and be acceptable in the Temple. But no union would let him in. Then, in late 1953 or 1954, he learned that the Teamsters Union might admit him. He went to Seattle and patiently waited, hoping to see Frank Brewster. He was not let in. He stated that he learned that Tom Maloney was a friend of Brewster's and might be able to help him. He then made contact with Maloney, offering to pay Maloney's way to Portland if Maloney would introduce him to John Sweeney, who at that time was still Oregon International Teamsters representative. Elkins was introduced to Sweeney and was allowed into the Union. He denied having paid Maloney any fee other than expenses for his help in this matter (U.S. Senate Committee Hearings 1957).

In mid-1954 John Sweeney moved from Portland to Seattle, where he was made Secretary-Treasurer of the Western Conference of Teamsters. By 1956 Sweeney died. 
Maloney indicated to Elkins that he knew Brewster very well and that strong political connections of the Teamsters gave Brewster much power. Brewster, in fact, could order Sweeney around. Elkins paid $\$ 450$ for Maloney's expenses and loaned him $\$ 500$. As a result, Elkins met with Sweeney several times. Elkins went to Seattle and had conversations with the Chief of Police.

Elkins denied a rumour that he gave $\$ 50,000$ to Pomeroy's campaign for Mayor of Seattle. But, according to Elkins, he did go to the Olympic Hotel in Seattle and met with Joe McKinley, a famous racketeer, reputed to be the 1940 's boss of Seattle rackets, gambling and bootlegging. Elkins later met with Sweeney and was told by him that Maloney was to get a piece of any action that should come out of their mutual arrangement. After being shut down in Seattle, Maloney came to Portland and helped with the Langley campaign. After the primary, Sweeney introduced Elkins to Crosby at the airport. Sweeney told Elkins that he wanted Elkins to meet Langley the next day at his office (U.S. Senate Committee Hearings 1957).

Langley Gets Teamsters Support. Elkins at this time mentioned his partnership with William Langley in the China Lantern, which operated illegal gambling. Continuing, Elkins said he was told that within ten days there would be a green light from Brewster to support Langley for District Attorney. Elkins indicated that he expected from the District Attorney warnings of raids and no abatement on his properties. Elkins at this time was suspicious of Langley and felt that Langley was tapping his own phones during conversations with Elkins.

Elkins said that attorney Henry Hanzen represented abortionists and was the man behind the scenes in Langley's primary campaign. A lot of 
money for Langley came through Hanzen, Elkins claimed. In addition, Elkins asserted that a man who allegedly cwned a lot of property, including supposed whorehouses put a lot of money into Langley's campaign, was Joe Snitzer (U.S. Senate Committee Hearings 1957).

Langley requested that $\$ 1,200$ be raised to pay the printing bills of his campaign, Elkins said. At this point, according to Elkins, Elkins went to see Crosby about backing Langley, and Crosby said he would not since the Central Labor Council was backing John McCourt. Crosby and his people did not even want to have lunch with Langley at that time. (It is important to recognize that all of this is Elkins' version, sifted through the Oregonian and under the direction of Robert Kennedy.) Elkins and his brother Fred, met with Hanzen and Langley, and Fred Elkins agreed to call Maloney. Crosby again refused to back Langley (U.S. Senate Committee Hearings 1957). Langley has since denied any knowledge of Maloney's involvement in his campaign for Multnomah County District Attorney (Langley-Uris interview 1980).

Whatever the real reasons for Teamsters support of Langley, the Langley campaign for District Attorney is an excellent example of a congruence of events and interests around a specific political objective.

Elkins apparently had understandings, as has been suggested earlier, with members of the Portland Police Department, but a less clear understanding with the County Sheriff's Department. The nature of these understandings, payoffs, activities and so on, are fairly clear though they cannot be proved. Indeed, indictments of officers, based on testimony of a police "snitch," did not result in any convictions of police officers. 
Elkins decided to commit himself to the operation of Langley's campaign with the understanding that he would be free to operate his own organization without much official harrassment from the new District Attorney. Maloney came down to Portland, ostensibly to work on Langley's campaign. At this time, Jim Elkins and his brother Fred each gave Maloney $\$ 100$ plus his hotel expenses.

Elkins said he began to make lawn signs for Langley's campaign and the Teamsters put the signs up (U.S. Senate Committee Hearings 1957).

A letter dated October 5, 1954, from Maloney to Elkins makes clear the relationship between the partners in attempting to get Langley elected. The letter begins:

Friend Jim,

Well, here I am back at Spokane and I really had to shoot both Barrells and when I connected Stan Terry with McCourt that did it. John talked to Crosby for an hour and Jim if that kid lets John Sweeney down it is not right and and it puts you and I right in the middle. About two weeks from now I will get the Okay from Sweeney when I pick him and Frank Brewster at the Airport here Saturday I will have that Malloy take him around to all the Big Freight Lines and Bakeries and have your man meet the men so they can go home and talk about meeting the next District Attorney. Now John wants him to go right into Terry Schrunk and he can mention Johns name and in to Newberger and that Woman Congressman and if you get that office opened I promise you that I will get some Financial Aid for the kid and get him elected..." (sic)(U.S. Senate Committee Hearings 1957, p. 367).

The consequences of not playing ball with Elkins in support of William Langley can be seen by what happened to pinball operator Stan Terry. Terry's connection as a pinball operator and his support for John McCourt were the reasons for Terry's ouster from the Teamsters Union, Elkins claimed. But, his disaffection from the general interests of the Teamsters in bringing all his men into the Union may have led to Terry's status as a non-person within the Coin Machine Men of Oregon. When Terry 
recanted and persuaded the Union leadership to allow him to rejoin, he had no further troubles.

The above letter clearly implies conversations between John Sweeney and Frank Brewster. Brewster gives clear direction as does Clyde Crosby for the support of William Langley for District Attorney.

Elkins gave $\$ 1,200$ to Maloney for Langley's campaign. Elkins further rigged up sound equipment and went to the Pacific International Exposition where he attempted to use his equipment.

According to Elkins' testimony before the U.S. Senate Committee Hearings (1957), then Sheriff Terry Schrunk ordered the sound truck out. Maloney called John Sweeney in Seattle. According to Elkins, Sweeney then called Schrunk who then allowed Langley's equipment to be used at the Pacific International Exposition. Elkins gave an additional $\$ 3,600$ in campaign money to Maloney plus the $\$ 1,800$ for Langley's printing bill (U.S. Senate Comnittee Hearings 1957).

Maloney indicated to Elkins. Elkins said, that the Teamsters would pay for Langley's California vacation where he would meet John Sweeney, Frank Brewster and other influential people within the Union. District Attorney Langley by this time had agreed, at least tentatively, with Elkins' demands for warnings in advance of raids and for no abatement procedures against his organizations. In November, after the election, Elkins went to the Olympic Hotel in Seattle and to San Francisco to meet with Maloney, Brewster, Sweeney and Langley (U.S. Senate Committee Hearings 1957).

By September of 1955 the partners in the tentative plan to involve themselves with vice activity in Portland had had a serious falling out. Elkins became suspicious of his partners and began to tape record their 
conversations, carrying a Miniphone. He felt that he was being manipulated into appearing a liar because he was paying the conspirators less then they expected. Was Elkins double-dealing his various partners?

Maloney clearly wanted to open his own gambling joints and wanted a piece of Elkins' profits. Whether the Teamsters leadership ever knew that this was Maloney's game is unclear. Certainly there is no clear evidence presented at the Hearings on this.

According to Elkins, the tajes that he made, which were later played in part before the U.S. Senate Select Committee on Improper Activities in the Labor or Management Field (1957), cover the plans for illegal activities in abortion, gambling, bootlegging, after-hours joints and prostitution. Yet this is not explicit on the tapes (Attorney General's Archives).

Elkins' apparent initial plan, according to Elkins himself, was to play the tapes to Brewster or Sweeney. Finally, he said, he met Brewster and was warned to lay off Crosby and Langley (U.S. Senate Committee Hearings 1957).

It is, of course, difficult to say whether Elkins was lying. There is documentation of his trip to see Brewster but none of what went on in Brewster's office. Here is Elkins' version:

As near as $I$ can remember it, I came into his room and I first sat down in his little waiting room. Three men came in, looked me over for a couple of minutes and walked out. Then, he came in and I went in his place. I'm looking around, and he says, "You don't have to be so afraid of me. I don't wire up my place." I said, "I am not afraid of you wiring it up, Mr. Brewster." He said, "I am going to tell you to start with I don't like the people you represent." And I said, "I don't represent any people, just Jim Elkins."

And he said, "Well, I'm going to tell you something else. I make mayors, and I break mayors. I make chiefs of police, and I break chiefs of police. I have been in jail, and I have been out of jail. There is nothing that scares me." 
And I said, "I don't want to scare you. All I want is to be left alone." He talked a little more, and he got red in the face, and he said, "If you bother my two boys, if you embarrass my two boys, you will find yourself wading across Lake Washington with a pair of concrete boots." I believe that was the expression. I said, "Let us name the boys." And the boys were Clyde Crosby and Bill Langley (U.S. Senate Committee Hearings 1957, p. 100-101).

During this encounter Brewster indicated doubts about Maloney but said that Joseph McLaughlin was O.K. Brewster complained that Elkins was not giving enough to "his boys." Elkins said that he was, from that time on, hassled. He received threatening phone calls and thugs visited his house.

Under questioning by Robert Kennedy, Elkins indicated that he caught two men hassling his wife at their home. Elkins said:

"Well, I pulled up to the curb, and I talked to them, and they left, and they didn't come back no more.

The Committee Chairman said: "You did what?"

Elkins responded: "I talked to them. Well, I pointed the shotgun at them, and I talked to them, and they didn't come back any more."

Kennedy said: "Did you do anything else with them?"

Elkins replied: "Yes, I did. One of them, yes, I treated him a little rough."

Kennedy: "What did you do with him?"

Elkins: "Well, I hit him on the head. I knocked him around a little bit, and put him back in the car and told his buddy that I was going to shoot the next person that came in my yard." (U.S. Senate Committee Hearings 1957, p. 102).

Apparently, the men never returned. Elkins nevertheless felt that the Teamsters had control of Sheriff Schrunk. He felt the Sheriff was not willing to help him, but some Portland policemen were (U.S. Senate Committee Hearings 1957). 
What is possible is that Elkins was indicating indirectly that he had some access to the police department but none within the Sheriff's department. It is not clear that the Sheriff's office was in league with the Teamsters Union at this point except through inferences made in the matter of Langley's campaign and the fact that Schrunk was supported by the Teamsters in his race for mayor against Fred Peterson.

Elkins' testimony on the period from around January, 1955 concerning meetings taking place at the Olympic Hotel in Seattle and San Francisco, indicated that Langley wanted Elkins to accept Tom Maloney as partner and cut him into his business. Maloney apparently had ambitions of his own (which may or may not have reflected the interests of the Teamsters Union) in terms of setting up the town for an increase in vice activity. This is supported by the tapes available through the Oregon State Archives. Elkins balked. He agrued that he did not have control of cardrooms as Maloney had thought. Maloney wanted, according to Elkins, to open three or four whorehouses. Maloney indicated that he wanted Elkins to meet with Ann Thompson, an alleged madam.

Elkins always denied having anything to do with prostitution though he was under indictment at the time of the Hearings for prostitution activities. There is much corroborative evidence, as shall be presented later, of the serious interest Maloney had in prostitution. There was also evidence of Elkins' interest in prostitution in the testimony of certain prostitutes (U.S. Senate Committee Hearings 1957).

The Plan. According to Elkins, Langley told him John Sweeney and Frank Brewster wanted him to put Joe McLaughlin "into the picture" (U.S. Senate Committee Hearings 1957). Sweeney, Maloney, McLaughlin and Elkins met at the olympic Hotel in Seattle. The disclission there 
centered around the pinball and punchboard issue. Sweeney, according to Elkins, insisted that Elkins sit down with Maloney and McLaughlin because Brewster wanted McLaughlin to come to Portland to keep Maloney out of trouble. According to Elkins, McLaughlin was to be the contact person with the District Attorney's office. Elkins and Maloney were to have nothing to do with the District Attorney, according to the plan. It was made clear at this meeting, according to Elkins, that the District Attorney would be given orders - that he would not be asked, but instructed as to how he was to proceed.

Elkins agreed to help McLaughlin and Maloney open a couple of joints of their own. He did not yet realize that he had to cut them into his territories and profits. Both men, according to Elkins, complained consistently that Portland was not an "open" town and that the Chief of Police would be removed if he did not cooperate more fully. They insisted Elkins must have police protection, though Elkins, according to his testimony, repeatedly denied that such protection existed (U.S. Senate Committee Hearings 1957).

On January 2, 1955, the successful, Teamsters-supported candidate for District Attorney of Multnomah County, Democrat William Langley, took office. Early in January, McLaughlin and Maloney registered at the Multnomah Hotel. All facts of hotel registrations, transportation tickets, etc., are verified through documents presented to the Committee and are available as appendices to the Committee's materials (U.S. Senate Committee Hearings 1957).

At this time, according to Elkins, there were discussions about who should be the investigators for the District Attorney's office. (Such investigators are crucial persons, usually from the police department or 
other law enforcement agency, who provide information upon which many of the warrants, particularly in the area of vice, are developed.) They also discussed setting up gambling and bootlegging activities on an increased basis, Elkins said. Elkins acknowledged the ownership of two bootleg joints and said there were only two others in the entire city. Elkins was told that he was to provide $\$ 2,000$ a month to Langley, to be cut between Langley, McLaughlin and Maloney. He indicated that he could not afford that amount (U.S. Senate Committee Hearings 1957).

At this point, according to Elkins, John Sweeney informed Elkins that he was to take orders from McLaughlin and that they were all to get along. Elkins indicated that he did not want to discuss his bribes to Langley in open session. The U.S. Senate Select Committee on Improper Activites in the Labor or Management Field (1957) allowed him to pass over this matter.

Elkins said he was supposed to be organizing the town for the conspirators. He was to be the front man within the legal community. He was to deliver money to McLaughlin. He gave them money, but it was money from his own operations rather than money collected from other illegal activities in Dortland. But, he said, he got into trouble because he could not provide accountings for the money. All of the conspirators were concerned that Sweeney and Crosby seemed unable to get the Mayor and the Police Chief to open the town to their interests (U.S. Senate Committee Hearings 1957).

McLaughlin and Maloney repeatedly came to town to talk with Elkins. Eventually Elkins met with Ann Thompson, alleged madam, at the Portland airport. Apparently neither of them were interested in an operation in Portland. She indicated that all she wanted from Elkins was his word 
that it would not work. She did not want trouble with McLaughlin and Maloney, and by implication, with Sweeney and Brewster (U.S. Senate Committee Hearings 1957).

The talks with Ann Thompson resulted in her decision not to open houses of prostitution in Portland. Before the Committee she indicated that she did indeed talk with Elkins about opening houses of prostitution. She attempted initially to minimize the role that Maloney played but did eventually acknowledge that Maloney had a significant role in setting up the prostitution plan (U.S. Senate Committee Hearings 1957).

Maloney repeatedly contacted Sweeney and at one point made a phone call in Elkins' presence to the Governor of Washington, Albert Rosellini. (Rosellini was identified with the vice activity network in the State of Washington by William Chambliss (1978).

By February 1955 John Sweeney met with Elkins. Sweeney requested that Elkins get on the ball. He indicated that Brewster expected McLaughlin to be able to run things. At this point, Elkins was more worried, he said, and had his brother look for bookie locations to open (U.S. Senate Committee Hearings 1957).

Elkins indicated that race results would be supplied through Associated and United Press wires. They were available through the Teamsters' paper in Portland. Elkins indicated that he questioned whether Ron Moxness, then the editor of the Teamsters' newspaper, would allow the use of the wire services for race results for bookie joints. Elkins was told that Moxness could be replaced, which did happen (U.S. Senate Committee Hearings 1957). 
The Group Falls Apart. There was a falling out in April 1955 among the conspirators. It lasted through May and June. At the end of April, Elkins had stopped paying anybody in the Seattle group. Yet by August or September Elkins was once more making payoffs because he was threatened by Brewster. He did not, he said, open any other joints. He indicated to the conspirators that they did not understand how tight the city was, that the city administration would not let him open any further operations. The conspirators believed he had unlimited influence to the Mayor and the Portland Police Department and thought he was lying (U.S. Senate Committee Hearings 1957).

One question remains unanswered here: did Elkins have such access? There is evidence that payoffs did occur, but there is no hard evidence that Elkins could have increased his hold within the city.

A pimp was brought down from Seattle by McLaughlin and Maloney. A meeting took place in the King Towers apartments arranged for by Elkins for the conspirators' use. He had already bugged this apartment. The pimp wanted to open three or four places in Portland. Elkins told him that he would be unable to operate for any length of time. A promise was made by the conspirators that Clyde Crosby was going to see the Mayor of Portland about the Chief of Police.

There is confirmation from all sources, including ex-Mayor Fred Peterson, that Crosby did go to see Peterson about replacing Police Chief Jim Purcell (Peterson-Uris interview 1980). Peterson said he refused to go along with Crosby's desire that the Police Chief be changed. In the interview Peterson reported that Crosby said he had orders from Seattle. Following this he was no longer supported by the Teamsters. Terry Schrunk received their support instead. 
Fred Peterson described the meeting in December 1955:

Clyde Crosby came to my office and stated he had an official message to deliver to me. He said, "I hate to bring this message to you, but it is an official message, and $I$ have to give it to you. Brewster, Sweeney and I talked this over, and I have been instructed to tell you that if Purcell continues to be Chief of Police, we will have to find another candidate for mayor to support."

During this discussion I asked Clyde Crosby for the reason that this action should be taken, and he stated that a man had been beat up, and he also said that a man had been innocently arrested for vagrancy. I told him if he would give me the details, I would look into the matter and take appropriate action. He stated that I could easily find out, and that the Teamsters' attorney, Jim Landye, was handling the case of the individual that had been arrested on a vagrancy charge. I told Crosby that I would not do anything about the removal of the Chief of Police whom I had appointed unless there was a reason for his removal, and Crosby told me to think it over, or they would find another candidate to support for mayor..." (Peterson's Affidavit, U.S. Senate Committee Hearings 1957, p. 552-553).

It should be noted that neither Fred Peterson nor former Police

Chief James Purcell were ever questioned in person by the U.S. Senate Select Comnittee on Improper Activites in the Labor or Management Field (1957). Their testimony was in the form of signed affidavits.

During this period Tom Maloney saw the Teamsters as the ultimate political weapon. According to Elkins, Maloney believed that the whole state could be taken over politically by the Teamsters. Elkins acknowledged some of their power, saying that Mayor Fred Peterson was ousted by the Union.

Elkins said that he went to Purcell and told him that he would get fired if he did not play ball. Elkins says that Purcell threw him out. Elkins further said that there were 10 to 15 houses of prostitution operating in Portland. Purcell would periodically close them down but there were rarely prosecutions (U.S. Senate Committee Hearings 1957). 
Purcell was eventually indicted by the Grand Jury subsequent to the Oregonian investigation for malfeasance but he was never brought to trial.

In January and February 1955 there were also discussions of the pinball and punchboard operations in Portland and how much money could be made. These discussions are supported by taped evidence presented to the Committee. Crosby, it was expected, would go to the City Council to get the ordinance changed to allow pinball operations. In fact, the ordinance on punchboard was changed to allow people to possess but not use the cards.

Elkins indicated that this involvement in punchboard included a partnership with Norman Nemer, Joe McLaughlin and Tom Maloney. They met at the King Towers and Nemer agreed to have Teamster stickers placed on his punchbaords which would give him an exclusive on punchboard operations. Maloney was to be hired as a bookkeeper for Nemer. Elkins was to receive $25 \%$ of the take. Nemer was to get $25 \%$, and McLaughlin was to get the rest to divide among the men in Seattle and his own team.

Nemer joined the Union and then informed the Coin Machine Men of Oregon of his decision. He was the first to join and they reacted angrily. No one else in the organization at that time was allowed into the Union. Only Jim Elkins and Nemer were members.

Nemer, according to his own testimony, got the Union stickers from Clyde Crosby. Nemer confirmed his involvement, indicating that sometime before February 15, 1955 he went to the King Towers with McLaughlin and Maloney. A discussion took place on the division of territories. The names of Brewster, Sweeney and Crosby were mentioned (U.S. Senate Committee Hearings 1957). 
There was little possibility that the Coin Machine Men of Oregon would remain independent. They had to come to terms with the Teamsters Union and those terms would be dictated by the Union. However, according to Elkins, the punchboard arrangement fell part in time largely because the Seattle men wanted more than $50 \%$ of the take, and Nemer and others were not interested in giving up that kind of profit.

Nemer further indicated that the Teamsters, who promised to keep pinball legal, were getting the lion's share of his operation. He was being financed through monies from Elkins and McLaughlin (U.S. Senate Committee Hearings 1957).

Maloney's bills paid by the Teamsters and a city directory listing of him as a Teamsters organizer made the link between Maloney and the Union clear. Bills indicated that Maloney and McLaughlin were at the King Towers and that they used Clyde Crosby as a reference in getting that apartment (U.S. Senate Committee Hearings 1957).

The King Towers Setup. The King Towers incident is an illustration of Elkins' ability to manipulate situations. Maloney was chased by a car through the West Hills and around town. In terror he ended up parked in front of the police station until dawn. Maloney turned to Elkins to ask for a place to stay. Elkins suggested the King Towers. What Maloney did not know was that there only was one apartment available and that Elkins had already bugged it. The decision to tape record conversations taking place in that building had long since been made. A friend of Elkins was installed next door to the wired rooms.

Stanley Earl Appears. City Council member Stanley Earl appeared next before the Committee and gave a history of pinball in Portland (U.S. Senate Committee Hearings 1957). Earl had been a member of the City 
Council from 1952. He had been very active in the CIO and a member of the IWW in the old days. He indicated that on May 18, 1955 Crosby threatened him and said that if he did not support the licensing of pinball, the Teamsters would not support him for re-election in 1956.

The City Council banned coin in the slot-operated devices beginning in July 1951 by a unanimous vote under Mayor Lee. Stan Terry appealed this decision to a three-man panel of Circuit Court judges of Multnomah County. The judges, by a two to one vote, ruled against the city. Portland appealed to the Oregon Supreme Court and won. Pinball machines were outlawed. The pinball operators then responded by removing the coin slots from the machines to avoid the ordinance. The city retaliated by banning all pinball devices.

By 1956, the Teamsters Union had collected enough signatures to force a referendum on the pinball issue. The ordinance would not be enforced pending the vote. In May of 1956 the people voted to uphold the ordinance against pinball. This referendum may have been influenced by the fact that by April 1956 the Oregonian had broken the pinball-related vice stories.

Earl said that the people who wanted to legalize pinball were the Coin Machine Men of Oregon, tavern operators and the Teamsters Union. The Teamsters did not officially attempt to organize pinball until 1955 , but Earl stated the Teamsters had supported pinball long before they had any official interest in it. He said they supported the pinball industry in July 1951, in fact. Pinball had been operating since 1935 and in those days was not licensed, merely taxed - $\$ 10$ to the State, $\$ 50$ to the federal government (U.S. Senate Committee Hearings 1957). 
Earl said he used to be in favor of pinball, seeing it as a revenue source for the city. He estimated that there were 2,200 pinball machines in the city. He said that on April 28, 1954, he switched his vote when a workingman's wife came to him and said her husband had lost all of his salary in one week playing pinball machines.

Crosby Answers Earl. Clyde Crosby responded in the Hearings by saying Earl supported pinball in 1951 before he had been on the Council. Earl changed his vote and attitude in April of 1954 because Elkins had leased his pinballs to Stan Terry until July 31, 1954.

Crosby accused Stanley Earl of being in cahoots with Elkins and the Oregonian journalists in the Bourbon and Ham Club. The allegations concerning the Bourbon and Ham Club were denied. Various witnesses indicated that the club was merely a device used to celebrate elections. The Bourbon and Ham Club held meetings at the Press Club during which everyone could drink all the bourbon, eat all the ham and play all the poker they wanted.

The club served as a meeting place for politicians and the press and, as such, was part of the established informal network in Portland. Indeed, the involvement of gamblers in occasional meetings of the Bourbon and Ham Club points out the essentially corrupt nature of the relationships between city, newspaper and gambling people (U.S. Senate Committee Hearings 1957).

Earl Rebuts Crosby. According to Earl, Crosby indicated to Earl that his message on pinball came directly from John Sweeney and other Teamsters Union higher-ups. The Teamsters supported Jack O'Donnell, then County Auditor, for Earl's seat, and 0'Donnell was given $\$ 4,750$ (a great deal of money in the mid-1950's) for billboards, radio, TV spots and newspaper space. 
Earl indicated at this time that Brad Williams, Oregon Journal reporter, was a very close friend of Tom Maloney's. Earl suggested that Williams was the author of a yellow sheet attacking him during the election contest. Columnist Drew Pearson used this information. It resulted in a libel suit against Pearson in Coos Bay, Oregon. (Earl lost the libel suit in 1958.) Elkins and Earl were not close, Earl insisted. Earl opposed pinball and supported the City Club in its opposition to organized vice.

They Sure Played a Mean Pinball. According to Elkins, Maloney wanted Elkins to break his pinball franchise arrangement with Stan Terry and take back his pinball machines. At the same time, Joe McLaughlin was attempting to persuade Budge Wright, another of the Coin Machine Men of Oregon, to take over Terry's routes. McLaughlin committed the Teamsters to giving Wright equipment after Wright lost the Bally distributorship. Wright was promised that he could get this distributorship and have any locacions he wanted through the Teamsters Union. Elkins had leased his 37 pinball machines to Terry because he did not want to hire new operators, and Terry already had the equipment and machines. Elkins apparently believed that pinball was doomed or dying in the Portland market (U.S. Senate Committee Hearings 1957). At this point in 1955, only Nemer and Elkins were unionized. Budge Wright, Joe McLaughlin and Fred Elkins formed a company apparently to take over Stan Terry's operations. The company was to be known as the Acme Amusement Company.

All this time, McLaughlin and Maloney were insisting that Crosby could get the City Council to change its mind on the pinball ordinance. Elkins disagreed. He stated that it would have meant a quarter of a million dollars or more in immediate profits if Acme had been successful in controlling all pinball in the Oregon market. 
In the spring of 1954, according to an affidavit by Budge Wright, there was a meeting at the Multnomah Hotel of certin members of the Coin Machine Men of Oregon. At that meeting were Stan Terry, Lou Dunis, Harry Ornsberg, John Sweeney and Lou Welcher, a San Francisco coin machine distributor. Discussion continued half-heartedly through 1954, according to Wright (U.S. Senate Committee Hearings 1957).

By November of 1954 Stan Terry had been kicked out of the Teamsters Union. In January of 1955 Elkins told Wright to meet with Joe McLaughlin who was identified as a Union organizer from California.

After the picketing of the Mt. Hood Cafe, the Coin Machine Men of Oregon signed up with the Union. A fair trade agreement was signed by the new Union members. This meant that city pinball distribution was divided through the Teamsters.

In further testimony, Elkins said he was told by McLaughlin and Maloney that Terry and Dunis must be kept out of the Union until Terry agreed to eat crow and pay a large fine to get readmitted. Terry went through a series of efforts to get into the good graces of Frank Brewster. Eventually Terry paid more than $\$ 10,000$ just to get in to see Brewster, who humiliated him. When Terry was finally readmitted, Maloney was very upset.

The Coin Mac'ine Meì of Oregon was not created by the Teamsters Union. It was a rationai response to opposition to pinball by the City Council later taken over by the Tearasters. A redefinition of the right of individuals to organize in their own interests took place. Kennedy and his staff in the Hearings seemed to suggest that this legitimate pressure group was part of an organized crime neisork by dint of the fact that pinball had become illegal. 
Stan Terry indicated that his difficulties with the Teamsters began in 1953. John Sweeney wanted all of Terry's men to be in the Union. Terry, already a Teamster, resisted unionization for his employees. When he realized what this would cost him, he went to Seattle twice and San Francisco once just to talk to Sweeney and Brewster about getting back into the Union. Pressure was put on Terry at various levels. The Mt. Hood Cafe picketing in February was just one example. Crosby, according to Terry, suggested seeing Sweeney in Sar Francisco. Terry eventually went to attorneys Black, Kendall and Fain, who also represented the Oregonian Publishing Company. David Fain called Jim Landye, attorney for the Teamsters Union, and explained that Terry was ready to join the Union and would sign any contract they wanted.

Terry's machinations in attempting to get back into the Union's good graces are an indication of the power of the Union. Terry indicated that Elkins told him that there was an attempt by Teamsters people to take part of Elkins' money from him. Terry denied paying the $\$ 10,000$ to get readmitted (U.S. Senate Committee Hearings 1957).

Teamsters and Oregon Politics. The U.S. Senate Select Committee on Improper Activities in the Labor or Management Field (1957) had heard dubious sources supporting James Elkins' story about the Teamsters moving into the Portland vice market. But support for his story also came from Howard Morgan, a well-known, respectable and responsible oldline Oregonian. He was head of the State Democratic Party and a member of the Federal Utility Commission at the time of the Hearings. Because of this, Morgan's testimony is perhaps the most supportive of Elkins' allegations and the most damaging to the Teamsters Union. Morgan said that the Union had never followed party lines in its position on 
elections. For example, it supported Paul Patterson, a Republican, for governor, while the rest of labor supported Joseph Carson, a Democrat. Patterson, the incumbent, won. In 1954, Teamsters supported Democrat William Langley for Multnomah County District Attorney against Republican John McCourt (U.S. Senate Committee Hearings 1957).

Morgan, as head of the Democratic party, heard about the Teamsters support of Paul Patterson a week before the Central Labor Council's paper, the Labor Press, made endorsements public. He held a meeting with Sweeney, Crosby, Malloy and others in the Teamsters Union and was told by Crosby that the decision had been made in Seattle (U.S. Senate Committee Hearings 1957). Morgan, at this time, attempted to find somebody other than Langley to run against John McCourt, but Langley, the only Democrat to file, ran unopposed for the nomination (U.S. Senate Committee Hearings 1957).

According to Morgan, Langley was not seen after the nomination until about six weeks before the end of the campaign when suddenly Maloney came down from Seattle. Maloney represented himself as being from David Beck, Frank Brewster and John Sweeney. He called himself a Teamsters official and immediately put Langley on what Morgan called "a 22-hour schedule" with plenty of money. Morgan indicated that many Democrats were frightened by Maloney, that he was not well liked, that he was not a man interested in good government (U.S. Senate Committee Hearings 1957).

According to Morgan, after the election Ken Rinke, County Democratic Chairman, and Morgan ran into Teamsters Maloney, Crosby, Sweeney and Jim Hagen and had coffee with them at the airport. Morgan and Rinke warned the Teamsters that they did not want them moving in on Portland. This comment was not well received, Morgan said. 
During a later period in the campaign, according to Morgan, Attorney General Robert Y. Thornton, the only Democrat elected to state office in 1952, wanted to investigate the Oregon Liquor Control Commission (OLCC) in a case of bribery. Republican Governor Patterson would not let Thornton investigate the OLCC in Multnomah County. The Oregon Constitution, Morgan pointed out, did not allow superseding of a local District Attorney's power without the governor's direct instruction.

Morgan described the pressure put on him in the matter of the OLCC investigation on December 10, 1954, at a Democratic dinner party:

Mr. Maloney showed up at that dinner and just before the guests were to sit down, with about 700 people in the room, 40 or 50 of them standing around within earshot and watching the performance, Maloney, with no warning walked up to me in the middle of the hall, and with a cigar between his first two fingers, thumped me on the chest, scattering cigar ashes all over a dark blue suit I had on, and said, "You make Thornton lay off that Liquor Commission investigation," in a very loud voice. Of course, I was angry and while brushing the cigar ashes off my clothes, I said, "That sounds like an order," and he said, "That's an order."

I then told him to go to hell, but the immediate question I asked him was, "What is your interest in the Liquor Control Commission? Why don't you want that investigated? Why do you care whether it's investigated?"

He said, "You know damn well what this means to us. Paul Patterson is our pigeon, and we don't want anybody shooting at him."

What this means is that Oregon is a monopoly state. The Liquor Commission is appointed by the governor. It is a three-man commission. It is directly responsible to the governor. Any embarrassment to the Liquor Commission, and there have been stories about scandals in the commission since it was established in 1933, is a tremendous handicap to the governor. It is his responsibility.

After I told Maloney that I would have nothing to do with Thornton's starting the investigation, and I would have nothing to do with his stopping it even if I wanted to, which I didn't, he retired then and talked to Clyde Crosby. Crosby then approached me, and in a more quiet tone of voice said, "Has Maloney been trying to give you a bad time?" And I said, 
"He has been trying." Crosby said, "Well, I would put it a little differently, but it amounts to the same thing. We wish Thornton would lay off." (U.S. Senate Committee Hearings 1957, p. 320).

At this time, according to Morgan, Attorney General Thornton announced that Governor Patterson would not let him investigate. Instead he would ask District Attorney Langley to help in the OLCC investigation. Morgan warned Thornton away from Langley, but Thornton did not apparently believe him. Four days later, Thornton called Morgan and said that he was right, that Langley had chickened out on the investigation, and Morgan then predicted correctly that if Thornton kept pressing the matter, the Republican governor would nevertheless have a Democrat District Attorney Langley - investigate the matter (Morgan-Uris interview 1981).

Morgan testified that the Teamsters attempted to remove County Commissioner Mike Gleason. Morgan believed that the Teamsters Union was attempting to take over law enforcement and government in Multnomah County and eventually in the whole state of Oregon (Morgan-Uris interview 1981; U.S. Senate Committee Hearings 1957).

By September of 1955 Morgan was convinced that the 1956 elections would result in a complete takeover of Oregon by the Teamsters. At that time, he said, he went to the press. Morgan went to Malcolm Bauer, then the editor of the Oregonian, Douglas McKeene, then the editor of the editorial page of the Oregon Journal, and Wendell Webb, then the editor of The Oregon Statesman. No one believed his story, Morgan said. It was not until James Elkins went to the Oregonian in the spring of 1956 that people began to give Morgan's story some credibility. 
In 1956, Morgan reported, Governor Robert Holmes had a deficit of $\$ 15,000$ in his $\$ 43,000$ election campaign and had been offered $\$ 10,000$ in exchange for reforming the OLCC. Morgan was sent to find out where the money was coming from and eventually talked with Matthew Spear, a liquor and beer distributor. Morgan said he asked Spear about the money at a luncheon and Spear indicated that the money he heard about came from Beck and Brewster and that they wanted a Teamster on the Liquor Commission in return for the $\$ 10,000$. Morgan said he refused the offer. A public official would be reluctant to put a Teamster on the OLCC after the scandal that took place in the 1930 's involving Beck, the Teamsters and the Liquor Commission (U.S. Senate Committee Hearings 1957).

Apparently, the Teamsters were interested in the OLCC position because they wanted control of selection and distribution of liquor from east coast distillers. This would enable them, during strikes on the east coast, to put pressure on those distillers by rejecting their product during labor disputes.

Under subpoena, Matthew Spear appeared before the U.S. Senate Select Committee on Improper Activities in the Labor or Management Field (1957). He indicated that he had worked for $K$ \& I Distributors in Seattle. The officers of that company included Dave Beck, Jr. and eventually Mrs. Dave Beck. Spear indicated that the $\$ 10,000$ was merely a hypothetical offer (U.S. Senate Committee Hearings 1957).

Elkins resumed his testimony and indicated that two members of the Liquor Commission staff were fired for accepting gratuities. One of these, Thomas Sheridan, came to Elkins, who did not at that time know him, Elkins said. Elkins took Sheridan to Crosby (U.S. Senate Committee Hearings 1957). Crosby, said Elkins, called Sweeney, who said, "We might 
as well see if we have bought a pig in a poke." This is a reference to Republican Governor Patterson (U.S. Senate Committee Hearings 1957). After a discussion with Governor Patterson, said Elkins, Crosby called and said that the matter was taken care of. Sheridan was reinstated in his job with a loss of only a month's pay.

Elkins insisted that, in 1955, Governor Patterson and Multnomah County District Attorney Langley had clandestine meetings. Maloney told him that the investigations of the OLCC under Langley would be a whitewash and that witnesses necessary to the investigation would disappear from sight. Langley's and Sheridan's conversations were recorded by Elkins, Elkins claimed (U.S. Senate Committee Hearings 1957).

Elkins said Joe McLaughlin had traveled with Clyde Crosby in May of 1955. This was confirmed by other witnesses. In San Francisco, Crosby and McLaughlin did stay at the Olympic Hotel in adjoining rooms and did take the same flight, further confirming Elkins' story (U.S. Senate Committee Hearings 1957, p. 743, Exhibit 37).

Clyde Crosby, in the first quarter of 1955, encouraged the relationship between Maloney and McLaughlin. There were in constant discussion regarding cutting up the vice pie in Portland. Using his clandestine tape recordings, Elkins presented what he said were the voices of the conspirators dividing up Portland. The first taped discussion played for the Committee seemed to center around the question of football gambling sheets. People allegedly involved in the football service were Maury Autschuller, Leo Plotkin and Bob Archer, operator of the Rialto Pool Hall. Archer balked. Elkins put pressure on Archer insisting that he must 80 along or be shut down by the District Attorney's office (U.S. Senate Committee Hearings 1957). 
Throughout this period, Maloney and McLaughlin tried to get Elkins to open up more bootleg, gambling and after-hours joints. Maloney wanted to get into prostitution, according to Elkins, and contacted Nate Zusman, owner of the Desert Roor nightclub, who put him in touch with two madams, Helen Hardy and Helen Smally (Big Helen and Small Helen).

In her affidavit, Helen Hardy stated that in May or June of 1955, Zusman indicated that he had reliable information that District Attorney Langley would see that she would not be bothered if she opened up a call house with Helen Smalley in Portland (U.S. Senate Committee Hearings 1957). Zusman offered backing and told her that Maloney was the man with the information on the District Attorney's office. Hardy then rented a house at 24th and Pettygrove, furnished it expensively, and opened. She said the Zusman and Maloney visited the house together. Two weeks after the house was opened, a police car was parked in front of the house every night from ten in the evening until three in the morning. She called Zusman and asked what the hell was going on. He put Maloney on the phone and Maloney then said that Zusman should not have said that it was safe to open.

Five weeks after opening, Helen Hardy said Police Chief Purcell and two detectives came to her door and told her to get out of business at once. She did. She relocated at 11 th and Glisan in the warehouse district, opening in October. Still scared, Helen Hardy talked to Purcell's brother, Bard Purcell, apologized and assured him that she did not mean to offend the Chief of Police.

Here is an indication again of the informal networks between the police and criminal elements. That Helen Hardy felt that she should make this apology to avoid further trouble is of significance to an 
understanding of how vice operates successfully in a city serving the needs of the vice customer and helping to maintain an established order in which there is no inaos or confusion.

Her apology, together with her move out of a decent residential neighborhood, was evidently enough. There was no further touble with the police. She quit in December 1955, she said, because there was not enough business for her and Helen Smalley together and that Smalley closed voluntarily in April or May of 1956 when the vice expose began (U.S. Senate Committee Hearings 1957).

Zusman, "The Mark of Stark," Appears. Nate Zusman was then called before the Committee. Zusman demanded a lie detector test, but only if Helen Hardy also took one. Robert Kennedy asked Zusman if he had ever been open after 2:30. He indicated that he had not.

Zusman: "I have been accused of everything, and I have vice men there every day, and I wouldn't even think of that."

Kennedy: "Why do all the vice men go to your place?"

Zusman answered: "They have no place else to go, I guess, so they come around to us."

Kennedy: "Is there something about your place that they like?"

Zusman: "We have a nice show."

Kennedy: "Do any other policemen other than vice men come to your place?"

Zusman: "We have detectives coming in and out. We have the men on the beat coming in and out. We have an open door."

Kennedy: "But mostly the vice squad?"

Zusman: "The vice squad come in quite often. They call roll there sometimes." (U.S. Senate Committee Hearings 1957, p. 474).

In lengthy testimony, Zusman admitted his involvement with criminals though each admission was made reluctantly. He indicated finally that he 
was at the whorehouse, as Helen Hardy had testified, but denied Hardy's version of their conversation (U.S. Senate Committee Hearings 1957).

Zusman stated that Alphonse Calabrese and Jerome Alderman, two investigators for the Senate Committee, were rude to him. As proof of this, he said that Brad Williams, an Oregon Journal reporter he had called, and his attorney who happened to be there, overheard his conversation and could corroborate this. Brad Williams is shown here in a crucial position of seeming involvement with a member of the vice community.

Zusman accused Police Lt. Carl Crisp of the vice squad of being a stooge for Elkins. Zusman also accused Crisp of attempting to put him out of business because he would not sell his club to him. Later, in a signed affidavit, It. Crisp denied the accusations of Zusman.

Zusman indicated: Leo Plotkin had worked for him and Plotkin had mentioned his connections with Maloney, Brewster and Sweeney; Maloney had been in constant contact with Zusman; Plotkin understood there was a District Attorney's connection for Swede Ferguson, another vice operator, that allowed Ferguson to stay open despite the illegality of his after-hours and gambling joints; Plotkins all this time was reporting vice operation locations to Langley through Maloney and was referred to on the King Towers tapes as "The Spy." (U.S. Senate Committee Hearings 1957).

"The Spy". Apparently Leo Plotkin became involved with Marie Maynard, a recognized operator of houses of prostitution and conversations on her behalf took place with Maloney. Maloney indicated to Plotkin that he would talk to It. Crisp, head of the vice squad. Crisp, according to Plotkin, told Maloney that Marie Maynard would have 
to close down her whorehouse for a while but could reopen later. Maloney admitted that Langley did not want a lot of whorehouses mushrooming up all over town, but would allow three or four houses to exist. Maloney had also indicated that Chief of Police Jim Purcell was uncooperative about allowing places to continue to operate (U.S. Senate Committee Hearings 1957).

Plotkin had indicated to Kennedy in Seattle that he believed that the Teamsters were trying to get rid of the chief of police and mayor in Portland. Plotkin now modified his testimony and indicated his involvement with football sheets, billiard parlors, etc.

Plotkin stated that Clyde Crosby secured an attorney for him when he was arrested. Plotkin was the man beaten by the police which occasioned Crosby's going to the Mayor to complain about the police department and to threaten the Mayor. Crosby allegedly demanded that the Mayor get rid of the head of the police department or lose the support of the Teamsters Union.

Bard Purcell, the Chief's brother, in his affidavit, confirmed that Helen Hardy did ask him about Tom Maloney, who was identified as a Teamster, and that she had the impression from Maloney that she would not be bothered by the police (U.S. Senate Committee Hearings 1957).

Later Zusman failed his lie detector test, a test he demanded so vociferously. But Zusman was not the only individual before the Committee to fail a lie detecter test or to refuse to take one.

The Outsiders Push Hard. If Elkins' and others' stories are to be believed, Frank Brewster had made a terrible misjudgment believing that McLaughlin could control Tom Maloney. Maloney, in his own ambitious way and with his own small-time orientation, appeared to be pushing far too 
hard at the Portland establishment, trying the relationships between the guardians of justice and the vice activists.

In response to the pressure from Maloney and others, Elkins opened up the Rialto and Elite billiard parlors as poker, dice and " 21 " houses (U.S. Senate Committee Hearings 1957). Both were immediately closed. This confirmed Elkins' understanding of his situation. Maloney and McLaughlin still believed Elkins was holding out money on them. He ended up givimg them close to $\$ 20,000$ in eight months, he said, but they were still unsatisfied. Langley, according to Elkins, insisted that they were was not getting enough from Elkins. This is confirmed by the King Towers tapes (Oregon State Archives, accession number 69A-542 n.d.). All of this money, Elkins argued, was coming out of his own pockets because he could not open any joints without the police closing them. (Langley, in 1980, emphasized his belief that Elkins was lying to get rid of a D.A. who would close down Elkins' power (Langley-Uris interview 1980)).

Maloney became interested in opening up a place in the black community. He went to see two operators in that community, Bob Seger and David Nance. Maloney attempted to persuade them to become involved with Tom Johnson in opening up places in the black neighborhoods. Maloney, exhibited no understanding of existing arrangements as attested to by interview subjects in 1980 (anon.-Uris interview 1980).

According to Elkins, Maloney's demands seemed unending. Elkins' efforts to get Maloney and McLaughlin off his back kept failing. Crosby, as was suggested earlier, kept insisting that Brewster and Sweeney wanted Maloney and McLaughlin in the Portland area. Soon Maloney was demanding a piece of the Chinese action. Maloney further asked that he get a cut of the abortion action, Elkins said (U.S. Senate Committee Hearings 1957). 
Elkins, throughout the Hearings, maintained that he had nothing to do with the abortion business, but other sources link Elkins closely with elements in the abortion community. His involvement with a Portland hospital which was reputed to be an abortion center is a case in point. According to police informants, Elkins' operations through the hospital were mainly as a source for narcotics for himself, but also as a possible connection for income from abortions (Reiter-Uris interview 1970).

By the time Maloney was making these demands, Elkins knew that McLaughlin and Maloney were complaining to Sweeney about him. There were discussions involving double-crossers of William Langley. He knew, for example, that Langley was not getting all of the money that Elkins was giving to Maloney and McLaughlin to be given to Langley. By then, Elkins was, he said, a frightened man. He decided that Maloney intended to frame him.

The transcriptions of the tapes as presented to the Committee showed Maloney, McLaughlin and Langley talking about being able to get rid of Elkins. Elkins was referred to on the tape as "The Character," and Langley as "The Kid" or "Abe Lincoln" or "Honest Abe." It was decided that they would either get rid of "The Character" or start operations in the county, weli away from him. Langley said that he could have Elkins put in jail. Both McLaughlin and Maloney worried that messing with Elkins would result in their having trouble themselves (U.S. Senate Committee Hearings 1957).

On the same tapes there were discussions of choices for the new chief of police, always with the assumption that the chief would be replaced. An affidavit was introduced into the Committee Hearings from Harvey (Swede) Ferguson, operator of gambling establishments and after- 
hours joints, indicating that Elkins had loaned $\$ 5,000$ to Ferguson. Ferguson had been referred to Maloney by Langley. After discussion involving Langley and Maloney, Ferguson had opened the Key Bridge Club and the Dance School, both of which were after-hours joints featuring liquor, dice and cards. Elkins would take $50 \%$ of the gross and the half remaining was given to Elkins to pay off Ferguson's debt. Plotkin was hired as his floor man to oversee the operation. The Key Club and the Dance School were alternately opened. As one was raided, the other would open.

By October or November of 1955, when Maloney was leaving town after the break-up of the partnership with Elkins, Swede closed his joints, feeling that there was no longer any protection left. Maloney was apparently insisting that Plotkin be fired, and Swede insisted that $25 \%$ of the gross of Elkins' money was given to Maloney, allegedly for protection, presumably to go to Langley (U.S. Senate Committee Hearings 1957).

On March 22, 1956, Elkins got Joe McLaughlin to sign a receipt allegedly for 1955 tax purposes involving the Service Machine Company, which was Elkins' front organization. Listed as Exhibit 39 on page 753 , it tended to support Elkins' claims of a business relationship with McLaughlin.

Lt. Carl Crisp, responding to accusations in the Hearings, presented an affidavit acknowledging that he met Maloney in August of 1955. Maloney identified himself to Crisp as a big man with the Teamsters. Maloney interfered in attempts to convict a notorious madam, Blanche Raye. Crisp was careful to emphasize that he knew of no certain link between Crosby and Maloney (U.S. Senate Committee Hearings 1957). 
In an affidavit, Bard Purcell insisted that Maloney talked to him about having to open the town up for vice. He wanted Bard Purcell to contact his brother, the Chief of Police, to tell him of that necessity. Maloney kept referring to Brewster and Sweeney in their conversations (U.S. Senate Committee Hearings 1957).

According to Elkins, Maloney and McLaughlin brought Morey Altschuler to Portland to run a horse book. Elkins indicated that he eventually considered going to the Governor or the Oregonian with his tapes as evidence, but that he feared that his own business operations would suffer thereby, and that he would not be taken seriously. Finally, he said, he went to see District Attorney William Langley with his tapes, apparently attempting to pressure Langely into taking some action.

According to Elkins' testimony at the Senate Hearings, Elkins went a second time to Langley's house and threatened to give the tapes to the Oregonian if Langley did not stop taking orders from Maloney and McLaughlin. Depending upon what was the real nature of Elkins' and Langley's relationship, this demand and threat could well have been a form of blackmail.

Elkins said that he played a part of the tapes for Clyde Crosby. The purpose of this was, he said, to prove that Maloney and McLaughlin were not sharing their take as agreed upon with Crosby, Brewster and Sweeney. Elkins said that Crosby wanted to take the tapes and play them for Brewster and Sweeney in Washington. But Elkins said he learned that Crosby told Langley that he, Crosby, could get the 70-plus hours of tape recordings and thus set up Elkins to lose the one bit of evidence that E1kins had against them (U.S. Senate Committee Hearings 1957). 
The Ex-Mayor Explains. Former Portland Mayor Fred Peterson (19521956) submitted to the Committee an affidavit dated March 2, 1957 . In late December 1954, he was introduced by Clyde Crosby to Tom Maloney at lunch. During that lunch, Crosby said he wanted Maloney to help manage Peterson's campaign in May of 1956. Peterson was noncommital, saying only that he had a campaign manager. He said that Maloney frequently came to the Mayor's office to give him unsought advice (U.S. Senate Committee Hearings 1957).

Maloney pushed himself upon those who did not really want him, a characteristic seen throughout his Portland career. Did Maloney create many of the problems? It is unclear whether Maloney was an agent of the Teamsters carrying out orders or an independent using and influencing the Union to become involved in Portland.

On Friday, June 17, 1955, Maloney sent a note to Mayor Peterson offering the help of the Teamsters in getting special interest votes. Maloney stated in his note that because Peterson "had guts," he would be helped. Maloney invited Peterson to contact him through Clyde Crosby. The help of Ron Moxness, editor of the Teamsters paper, was offered in the mayoral race.

By late July or August of 1955, Maloney went again to Peterson saying Nance and Seger would get the black vote for Peterson if they were allowed to operate in the black area. This fits with earlier accusations that Maloney was trying to get a piece of the black gambling and vice activity.

But Tom Johnson pretty much coordinated vice within the black community. Johnson now faced an outside force that was attempting to rearrange the delicately established relationships between the 
authorities and the various vice operators. Johnson probably did not want or need partners in either his community businesses or the E-R property deal, yet Teamster clout made him accept, at least outwardly, the new arrangement.

Peterson, according to his affidavit, refused Maloney's offers. Maloney then asked to talk to Chief Purcell, seeking a special introduction, which was denied. Maloney later went to Peterson asking for a meeting between Purcell and Langley, who apparently were then feuding. How Maloney would fit in as a go-between is unclear unless one considers that Maloney was involved closely with Langley. Perhaps Maloney planned to use his supposed Teamsters clout to form an agreement to divide Portland among rival factions. By December of 1955, Clyde Crosby had come to Peterson and said that Brewster and Sweeney wanted Purcell out of office, as mentioned earlier (U.S. Senate Committee Hearings 1957).

The extortion materials used by Elkins included tapes he had made of others without their permission. Some of that material, never used by Elkins, came from a phone tap that was in violation of federal wiretap statutes. This will de dealt with later.

Did the Sheriff Take a Bribe? Elkins, late in his U.S. Senate Select Committee on Improper Activities in the Labor or Management Field (1957) testimony, presented yet another story which would have great impact on Portland politics. Elkins began by saying that he had an interest in the $8212 \mathrm{Club}$, a club in the Kenton district ostensibly owned by Clifford 0 . (Jimmy) Bennett. Elkins said that he was paying Maloney and McLaughlin in part out of the proceeds of this club. Plotkin (The Spy) told Maloney that the 8212 Club was not doing that well. Elkins alleged that Maloney contacted Ray Kell, identified in the Hearings as 
the Sheriff's campaign manager in the Schrunk mayoral campaign against Peterson. Maloney allegedly told Kell that Schrunk should raid the 8212 Club (U.S. Senate Comittee Hearings 1957).

Elkins said that on September 11, 1955 Schrunk did raid the 8212 Club, but only three or four drunks were arrested. He said that Clifford Bennett, the club operator, told him that he had given Schrunk $\$ 500$. According to Elkins, Laura Stone, bookkeeper at the Kenton Club, told him that they were $\$ 500$ short, and Deputy Sheriff Wally Wallins told Elkins shortly thereafter that he could go ahead with the operation of the 8212 Club in Kenton.

Clifford Bennett was then called to the stand and refused to testify. Virginia Jenkins, bartender at the club, described the raid. She said that two sheriffs came into the place at 3:30 a.m., that there was visible gambling going on, that there was card playing and craps and that there was money on the tables. She said that Bennett talked with one of the deputy sheriffs. She said that she found it strange that Sheriff Terry Schrunk was part of the raid. Bennett went upstairs and returned at once. Bennett then told her that the raid was occurring because he forgot to take care of Schrunk. Bennett then asked her for a manila envelope and went outside. She stated that this was a county sheriff's raid in the City of Portland, an unusual occurrence in and of itself (U.S. Senate Committee Hearings 1957).

John W. Vance, an admitted thief, said that he was at the $8212 \mathrm{Club}$ the night of the raid, that he was working as a checker for Elkins and that Bennett asked him, "Isn't it better to pay $\$ 500$ tonight rather than $\$ 15,000$ tomorrow?" He saw Bennett put $\$ 500$ in an envelope. (It must be pointed out that Vance and the others, as Elkins' employees, were not the 
most reputable of witnesses.) (U.S. Senate Committee Hearings 1957). Laura Stone further indicated that Elkins bankrolled the 8212 Club for $\$ 1,500$; that when the club was closed that night, Bennett returned $\$ 1,000$ to Elkins and told her that the $\$ 500$ had been paid to Schrunk (U.S. Senate Committee Hearings 1957).

Under subpoena, Merlin L. Tiedeman, a Portland policeman, testified that he and his partner Lowell Amundson received a radio call at 3:30 a.m. on the night of the raid on the $8212 \mathrm{Club}$. He was told by the Sheriff to come to Denver and Kilpatrick Streets and to pick up a lost or stolen bicycle.

At that address, he said, he saw Bennett come out of the club, talk to the Sheriff, go back into the building and come back out, talk briefly to Schrunk again, go around the corner where there was a water fountain and a telephone pole and put "something" behind the pole. He said that Schrunk went over to the pole shortly thereafter and picked something up (U.S. Senate Committee Hearings 1957). Officer Dick Sutter, another Portland policeman, was also there and was said to have remarked, "That crooked son of a bitch."

Visibility was good, the policeman reported, and the action took place less than 50 feet from them. Officer Lowell Amundson confirmed seeing the same things that Officers Sutter and Tiedeman said they saw at the 8212 Club (U.S. Senate Committee Hearings 1957).

Frank Daniels, identified as an unemployed bartender, testified to the Senate Committee that he, while out looking for a job, perceived the raid and saw Schrunk pick up the enveIope near the 8212 Club (U.S. Senate Committee Hearings 1957). He stated that after the raid, he asked Bennett what was happening, and Bennett said he was almost arrested, but 
that now everything was okay. He said that he told the story around town, and eventually the word got back to Turner and Lambert of the Oregonian and they interviewed Daniels (U.S. Senate Committee Hearings 1957).

Terry Schrunk, by 1957 Mayor of Portland, appeared before the Committee. (Schrunk was Sheriff from 1949 to 1956 and Mayor from 1957 to 1973). He began his testimony:

I am astounded and amazed that a Committee of the United States Senate is being used, without any knowledge on the part of you gentlemen certainly, for political purposes such as this." (U.S. Senate Committee Hearings 1957, p. 595).

Shortly thereafter, the Committee, which did not treat Mayor Schrunk as well as it treated Elkins, interrupted his statement and pushed him hard. Schrunk requested that an affidavit by the previously mentioned operator of the $8212 \mathrm{Club}$, Clifford Bennett, be admitted into evidence. But the Committee refused Bennett's affidavit saying that since Bennett would not testify and took the Fifth Amendment, his affidavit would not be appropriate. Schrunk then stated that Bennett told him that Wallace Turner of the Oregonian threatened Bennett, saying that the Hearings were all set up and that Turner did not want Bennett to mess it up.

Schrunk suggested that the Committee was using Wallace Turner as a consultant. Schrunk argued that Turner had an interest in the outcome of the Committee's hearings (U.S. Senate Committee Hearings 1957). It is true that the Oregonian reporters had a vested interest in the outcome of the Hearings. The Committee relied upon the Oregonian's version of the story. The Committee never called Doug Baker, Rolla Crick or Brad Williams of the Oregon Journal as witnesses and rejected Schrunk's suggestion that they might be called to give a balance to the matter. 
What might have happened had they given testimony? Hindsight and what-if's are irrelevant to this kind of history, but the U.S. Senate Select Committee on Improper Activities in the Labor or Management Field (1957) was definitely biased in that it did not choose to hear those witnesses, witnesses that presumably would have been available to the Committee had they been sought.

(In 1958, Schrunk was tried for receiving the $\$ 500$ sum from Bennett and was found not guilty. A significant number of the police witnesses changed their testimony by the time of the trial saying they were not sure Schrunk took anything at all.)

Schrunk Strikes Back. Mayor Schrunk accused Elkins of being involved in electing the mayor of Seattle as well as supporting Peterson against Dorothy McCullough Lee. Schrunk further accused Elkins of controlling law enforcement in the police department and some sheriffs with bribes and blackmail. He further labeled Elkins a major vice lord of Portland. He stated that Crosby never approached him with any illegal proposition and pleaded that the Comnittee talk with Journal reporters for an objective position. He arged that the Journal was fair and the Oregonian not (U.S. Senate Committee Hearings 1957).

Senator Joseph McCarthy of Wisconsin responded that Elkins had been corroborated so far by other sources. Robert Kennedy jumped in to point out that a document that supposedly was prepared by the Oregon Journal for the Committee was actually prepared by Brad Williams and that the Journal was in fact going to discipline him for it because it contained false statements.

The Chair, Senator McClellen, then dimissively said of the Journal people that they could write what they wished and contribute it to the 
Committee, but that they would not be subpoenaed because it already was becoming too expensive.

Schrunk said that the Oregonian was using the Hearings as a device to libel him. He said that in 1950 James Elkins and his crowd put up Glen Ackerman on the Republican ticket and Bard Purcell, brother of Chief Jim Purcell, and then a police officer with the Portland Police Department, on the Democratic ticket in an effort to defeat Schrunk for Sheriff. The Committee again did not allow Schrunk to continue with this line of testimony (U.S. Senate Committee Hearings 1957).

Schrunk was never allowed to make a full explanation. Yet he admitted knowing Maloney and knowing that Maloney worked on Langley's campaign. He denied knowledge of work by Maloney on his own campaign. The Committee was clearly attempting to link Schrunk with Maloney.

Schrunk continued his version of the 8212 Club incident. He stated that on September 2, 1955, James Madison brought a bad check from the 8212 Club to Schrunk's attention. Schrunk then had Detective Minielly check out both the check and why the club, which was supposed to have been closed, was open. Schrunk explained that in 1954 he had asked the Oregon Liquor Control Commission and the city police to close the 8212 Club. On December 12 and August 26, 1954, there were raids on the club. When Minielly checked the matter out in September of 1955, he discovered that Bennett had rented the place and seemed to be close to some city policemen, according to Schrunk. Minielly said to the landlady that if the city police did not close the place down, the county police would. Bennett apprently tried to contact Minielly and Minielly refused to talk with him. 
At this point, Schrunk said he ordered his uniformed police to get inside the private 8212 Club. It is interesting that Schrunk did not order undercover police into the club but attempted only to bring in the uniformed policemen.

Apparently, two officers did follow a crowd into the club while in uniform. The officers said they saw blackjack being played, but that they saw no money changing hands, said Schrunk. Schrunk argued that a search warrant, which required evidence, was needed in order to get into a private establishment. The city police could get in because of a city law relating to such an establishment. But the County Sheriff's office was limited by state law which required a search warrant. Schrunk emphasized the complexitites of getting a conviction in a gambling case which involved money changing hands, money being visible and so on.

The club was closed on the 10th because Minielly had hassled the landlord on the 9th. Early on the 11th Schrunk discovered that the club was again open, and the raid took place. Schrunk indicated that he arrived after the raid and was invited inside by Bennett but saw nothing. Schrunk said that only a few drunks who were outside the club could be arrested because there was no known exchange of money visible to the officers (U.S. Senate Committee Hearings 1957).

Schrunk futher said, under questioning by the U.S. Senate Committee, that no abatement proceedings were undertaken because the place was closed down after this and that there was no real evidence. Schrunk repeatedly denied receiving the $\$ 500$ and emphasized that it is necessary to observe money changing hands to do anything in a gambling place. 
This is a questionable matter. Why did Schrunk not send in undercover officers? Why send in uniformed officers?" And more importantly, why not attempt to have undercover officers engage in gambling activity? But Schrunk emphasized that a history of disorderly operations must be shown in order to abate a place or to padlock it and that only uniformed men were available at $3 \mathrm{a} . \mathrm{m}$. Yet the place had been raided twice before the 11th. With plainclothesmen it should have been easy to prove a gambling charge.

Mayor Schrunk insisted, in direct contrast to previous witnesses, that there were no clear evidences of gambling. Schrunk asked that the Committee call the county policemen involved in the raid to testify.

Senator Joe McCarthy responded, asking why he did not close the club. Schrunk kept insisting that he did not have the authority. One question then remains: Why did he conduct the raid in the first place? (U.S. Senate Committee Hearings 1957).

Mayor Schrunk said that he had tried to raid another place of Bennett's in the city earlier, but that place was closed because Bennett had been tipped off. He said that the Oregonian had also been tipped and was waiting at the site of the raid before the Sheriff's officers got there. Schrunk was then asked, "How many times did Sheriff's officers make raids within the City?" (U.S. Senate Committee Hearings 1957) Schrunk acknowledged that there were 20 to 30 such raids. He insisted that they only took place after complaints that city police were not doing anything to deal with gambling. Elkins' employee Virginia Jenkins emphasized again that there was both drinking and gambling going on while the two uniformed officers were in the place (U.S. Senate Committee Hearings 1957). 
Schrunk admitted that he was on the corner by the fountain but denied picking up any kind of package. He pointed out that it would be illogical that he would do this right in front of a group of policemen who were parked across the street, especially police from a rival jurisdiction. This is important. It does seem unlikely that Schrunk would accept a bribe in such a bold and obvious manner (U.S. Senate Committee Hearings 1957).

Committee Counsel Robert Kennedy then began to pressure Schrunk. Kennedy asked how it could be that eight officers including two who worked for him could all be testifying against him. Schrunk then offered to take a lie detecter test from a reputable agency. Eventually a lie detecter test was agreed upon, to be given by the Secret Service. Schrunk said that he had been unfairly treated in similar circumstances. (Schrunk flunked a lie detecter test administered by the State of Oregon. Schrunk explained this by insisting that test was a frame-up, that somebody had "gotten to" the agency giving the test.) (U.S. Senate Committee Hearings 1957). Senator Sam Irvin said that lie detecter test are, at best, a dubious check of honesty and are not always admissible in courts of law.

Responding to the suggestion that he was one of the Union's men, Schrunk emphasized that his election was supported by several unions, including the Teamsters, and by businessmen, church and civic groups. He stated that the University of Portland and the Oregon Journal supported his electoral efforts.

Schrunk admitted that he knew Clyde Crosby. He indicated that he knew Maloney only as a guy from Seattle who helped Langley and denied personal knowledge of Jim Elkins. He also said that Elkins was into 
prostitution as well as other rackets and that Elkins was a dope addict. He insisted that there were people who said that you must know Elkins to stick around Portland and be involved in local politics, but that he emphatically did not agree (U.S. Senate Committee Hearings 1957).

Portland Policeman Richard Sutter testified through affidavit that he was ordered to watch Schrunk's house and inform his superiors the minute Schrunk left his home. Schrunk introduced the affidavit himself to emphasize collusion between the city police and vice operators. Sutter indicated the surveillance was carried on from February 22, 1956 to March 30, 1956, and was done because officers were afraid that Schrunk would raid the vice operators. Schrunk indicated that over $\$ 80,000$ was spent on watching him. Schrunk further indicated that the Grand Jury called into the case initially at the instance of the Oregonian had ended up by indicting Elkins more often than any other individual.

A February 17, 1957, statement by Katherine Weeks, a convicted prostitute, was read into the record. She said she worked in a house from which Elkins collected money. The house was run by Jerry Rogers, Ray Clark's wife. Weeks swore that many of the women working in the house were hooked on narcotics supplied by Jim Elkins (U.S. Senate Committee Hearings 1957).

A second affidavit by officer Sutter was introduced. Sutter, who initially indicated that Schrunk had taken the bribe, stated that he was no longer sure of anything in regard to the incident.

Schrunk acknowledged that one of the members of the first Grand Jury investigating the bribe issue, Mrs. Jane Rossman, voted against him one day then changed her vote the next. He acknowledged that the day she changed her vote her husband was appointed to the Zoo Commission and that 
on that day she had talked with Ray Kell, Schrunk's campaign manager. Kennedy then read a statement from the judge that threw the Grand Jury out because of the irregularities of Jane Rossman's actions (U.S. Senate Committee Hearings 1957). While there is no clear financial or power advantage to being on the Zoo Commission, such an appointment did carry a certain social status.

Robert Kennedy pointed out in an attack upon Schrunk that Harvey (Swede) Ferguson's operations in gambling, after-hours joints and illegal liquor at the Taft Hotel and Tom Johnson's Keystone Club operation had had no abatements against them despite their notorious operations. Kennedy then presented a list of 35 clubs he claimed were operating under Terry Schrunk as Mayor. He claimed that only three of them had ever been hit in raids while Schrunk was Mayor. (A later examination of these 35 clubs by the Portland Police Department suggested that most of the operations as listed by Kennedy's investigators either never existed or had not existed for some time.)

Twenty-one of the listed clubs turned out to be in what was then known as either the "North" part of town or the "colored section." One was a Chinese gambling place near Williams and Russell; another, the 35th, turned out to be the Fireside, a notorious gambling retreat in the city of Milwaukie, south of Portland and outside of Schrunk's jurisdiction. It was at the Fireside that many of the business community used to gather to gamble in the days when the Pago Pago, owned by Al Winter, had been closed by Dorothy McCullough Lee. Of the remaining places, most were in the Northwest and Southwest, and virtually all of them were operated by such figures as Blanche Kaye, Marie Maynard, Nate Zusman and others. Most were call or bawdy houses. 
Crosby, Elkins and the Teamsters. Teamster official Clyde Crosby was then called to the stand and explained that his arrest in Arizona when he was a teenager was because of a theft of food (U.S. Senate Committee Hearings 1957).

Crosby argued that the Oregonian, James Elkins and local underworld figures were responsible for his indictments. He said that John McCourt was supported by Jim Elkins in the District Attorney contest in 1954, which was why Crosby got the Union to support William Langley (U.S. Senate Committee Hearings 1957). After November of 1954, the Teamsters, Crosby admitted, did start to organize pinball machine distributors and routes which involved 125 to 150 people. This happened at a time, he said, when he found out Elkins had pinball machines in the Labor Temple. Crosby said he used his influence to keep Elkins out of the Union because Elkins was a gangster and that Elkins went above his head at least once to try to get into the Union. This dovetails closely with Elkins' own version of what happened.

Crosby said that early in 1955 Stan Terry called saying that he had bought Elkins' routes. Crosby stated that he did not believe this urtil two months later. It was for that reason that Terry and Dunis were not let into the Union until March of 1955. Crosby went on to state that he was confused and disturbed when Stanley Earl, who used to support pinball, suddenly opposed it (U.S. Senate Committee Hearings 1957).

A 1980 interview with a former policeman who arrested Jim Elkins for narcotics use, indicated that City Councilman Stanley Earl was "up to his neck in crooked activities." This man, now a journalist also worked as a private investigator for Drew Pearson on the libel case against Earl (anon.-Uris interview 1980). 
Crosby indicated that Earl's anti-pinball position was instigated by Elkins, who he suggested was a confidante of Earl's. It was Elkins, said Crosby, who wanted the Teamsters to be involved in local politics. He wanted Teamsters' help in shaking down taverns to force them to take Elkins' coin machines. Crosby said that he asked Governor Smith to have the Attorney General investigate the Portland situation.

Crosby insisted that one night he saw Elkins and Police Chief Purcell talking together. After this, he confronted Peterson with Elkins' power. Peterson said he had never heard of Elkins, which led Crosby to believe, he said, that Peterson was controlled by Elkins (U.S. Senate Committee Hearings 1957).

Clyde Crosby indicated that cab drivers in the Teamsters Union kept complaining to him that uniformed and vice officers were telling cab drivers to take customers only to Elkins' approved list of joints. Anyone that operated without Elkins' approval got raided by the police. Raids on Elkins' places were extremely rare, and when they did occur, Elkins was always informed ahead of time so that he could get expensive equipment out of sight.

Crosby stated that he received veiled threats from Elkins ordering him to support Peterson. His wife and children were subject to phony telephone calls. Crosby said that he purchased a gun and put the word out in the community that he had done so, hoping that Elkins would leave him alone. He then applied for a gun permit from the Sheriff's office (U.S. Senate Committee Hearings 1957).

However, when he sought a gun permit, he did not inform the Sheriff that he was an ex-felon, having been convicted of burglary under the name Bob Harper in Arizona. When the F.B.I. reported to Sheriff Terry Schrunk 
that Crosby was an ex-felon and should not be in possession of firearms, Schrunk either did not know about or sat on the report of the F.B.I. Only when the Oregonian revealed this did Scinrunk rescind the gun permit. Shortly thereafter, Clyde Crosby, under pressure about lying on his permit form, resigned from the Exposition-Recreation Commission.

If Clyde Crosby's problems were limited to his dishonesty in applying for a gun permit, and if all of his contacts with James Elkins were limited to a secondhand, reputed role in a profit-making real estate scam, the importance of Crosby's involvement and of the Teamsters Union itself would be fairly limited. However, according to a sensationally presented copyrighted article by Wallace Turner and William Lambert appearing on April 22, 1956 on the Oregonian's front page, such was not the case. Turner and Lambert stated that on May 18, 1955, while Crosby was the International Representative of the Teamsters Union, he requested City Councilman Stanley Earl's support for a vote to continue the operation of pinball machines in Oregon. Earl was made to understand that if he did not vote as requested, he would lose Teamsters Union support.

Clyde Crosby said all the Teamsters Union wanted from Terry Schrunk was to get rid of Elkins' organization. Crosby suggested in his Senate Committee testimony that Elkins controlled Circuit Court judges and one Supreme Court judge. He emphasized Commissioner Earl's influence with the press and Earl's role in the Bourbon and Ham Club, which had its costs borne by Jim Elkins. Crosby said that Oregonian reporters Lambert and Turner engaged in a smear of him because nothing else had worked in trying to smash the Teamsters. They hated the Teamsters because the Union was against Peterson (U.S. Senate Comnittee Hearings 1957). 
The Oregonian, he asserted, had viciously attacked Thornton on the occasion of Elkins' indictments. Elkins was far more sinister than the Oregonian had ever admitted. Crosby insisted that Elkins used wire taps for blackmail purposes. He repeated his accusations that Turner and Lambert had a "weird" and close relationship with Jim Elkins. Crosby acknowledged knowing Brewster, Beck, Maloney, McLaughlin and Frank Malloy. He said he met Maloney only in August or September of 1954 and was introduced to McLaughlin through Maloney in 1955.

Crosby indicated that Maloney was a "fabulous character" who had all sorts of capabilities, but that he, Crosby, was sold a bill of goods by Maloney. He admitted to knowing Elkins socially but said he hated and feared him. He denied having lunch with Elkins in 1955 and then admitted that he was not sure whether he had or not (U.S. Senate Committee Hearings 1957).

He, likewise, had no recollection of having dinner with Elkins. When confronted about a meeting allegedly between Sweeney and Elkins that he attended at Amato's Ho-Ti Supper Club, he acknowledged the meeting, saying only that Elkins joined them there, and it was not intended that Elkins be at that dinner. He admitted that Elkins had come to his house twice: first, he says, to extort $\$ 10,000$; the second time in an effort to be friendly.

It was through the tapes, Teamsters' International Representative Clyde Crosby claimed, that the extortion attempt was being made. Crosby admitted hearing the tapes from Ray "Dopehead" (Crosby's word) Clark with Brad Williams. Crosby did not ask how Journal reporter Williams got the tapes. He had heard, but did not say how, that Williams was going to be playing the tapes for the State Police at Williams' house. He did not 
know or remember who told him. He stated that he was uninvited but he brazened his way in and listened to three or four hours of wire recordings. He did not hear himself, but only heard references to himself. When asked to give his copies of the wire recordings to the Committee, he offered to do so as soon as he was home. However, the tapes were never presented (U.S. Senate Committee Hearings 1957).

The Committee was clearly dismayed and confused as to why Clyde Crosby was admitted to Brad Williams' house along with the state policemen to hear the tapes.

As Senator Mundt said:

What transpired? You got to the house, invited yourself in, and they said, "Gee, Clyde, come right in. I forgot to invite you to the party. We are happy to see you." Or did they say, "You cannot come in," or what did they say? What was their reaction? (U.S. Senate Committee Hearings 1956, p. 711).

Crosby indicted that their reaction was embarrassment, but that he was fighting for his life.

Senator Mundt then replied:

I can understand your motivation perfectly. I am just wondering what their reacton was.

Kennedy then questioned Crosby very intensely:

Kennedy: You have said Elkins is head of a syndicate.

Crosby: Yes, perhaps a little strong word.

Kennedy: What about Elkins' employees working on your party room? (U.S. Senate Committee Hearings 1957, p. 711).

Elkins indicated to the Committee that Crosby never paid him for the work on Crosby's basement party room. Crosby insisted that he later learned that the men working on his party room were Elkins' men and that he paid the person he contracted with in the matter, Tom Maloney. 
Maloney may very well have received the money and not given it to Elkins. Thus again we see a situation in which it is possible that Tom Maloney failed to pass on monies as he had agreed.

Elkins' employee James Jenkins refuted Crosby's evidence, saying that he had worked on Langley's campaign as an employee of Elkins. Jenkins claimed that he was one of the men who was involved in the repairs and improvements in Crosby's basement (U.S. Senate Committee Hearings 1957). He was with Elkins' worker Barney Kane. They drove Elkins' trucks marked Service Vending Machine Co. and parked in Crosby's driveway.

Jenkins alleged that Crosby said, "If the thing on the E-R clicks, we' 11 have money for everything" (U.S. Senate Committee Hearings 1957, p. 721). Jenkins said that Crosby showed him the area where the E-R site would be. Two slot machines of Elkins' were delivered to Crosby's house prior to the fixing of the basement. Later Crosby admitted the gift but said he did not know from whom it came (U.S. Senate Committee Hearings 1957)

These were Elkins' workers, they had a vested interest. But Crosby's testimony was being refuted. The materials alone on the repair of Crosby's house, it developed, cost more than $\$ 800$.

It should have been clear to Crosby that Elkins' men were doing the work on the basement. It took several days to do it. It was extensive work for which the total bill was only $\$ 200$ and Elkins' marked trucks were in Crosby's driveway (U.S. Senate Committee Hearings 1957).

At this point Crosby was asked if he ever discussed with Elkins the Broadway Bridge site. Crosby refused to answer and was dismissed (U.S. Senate Committee Hearings 1957). 
Where's Jimmy? A telegram from Arden Pangborn, editor of the Oregon Journal, was read into the record. The telegram indicated that Clifford 0. (Jimmy) Bennett would not testify to the Committee because he had been followed by Elkins' agents into California, Nevada and other places, and feared for his life. The Committee would not allow Bennett's or Sutter's affidavits admitted as evidence since they would not testify under oath (U.S. Senate Committee Hearings 1957).

On Friday, March 8, 1957. the Journal indicated in an interview that Bennett, hiding in Vancouver, Washington, denied payoffs on December 5, 1956. The statement denying any payoff to Terry Schrunk was witnessed by Cliff Alterman and Sheriff's Detective Minielly. (Cliff Alterman is the law partner of Ray Kell and Ted Runstein today.)

On December 19, 1956, a second affidavit was obtained from Bennett in Great Falls, Montana. And by November 3, 1956, Officer Sutter had changed his story, insisting that his notebook of September 11, 1955 showed he worked with Officer Lindholm, not with Tiedeman or Amundson.

Thomas Maloney was called to the stand and took the Fifth, but he did deny ever being employed by the Teamsters Union or being a Teamsters official (U.S. Senate Committee Hearings 1957).

Joseph P. McLaughlin was called before the Committee and invoked the Fifth Amendment (U.S. Senate Committee Hearings 1957).

The Mayor Backs Down. On Tuesday, May 12, 1957, Mayor Terry Schrunk returned to the Committee after having agreed to take the lie detector test and then having balked at several of the questions. Schrunk agreed to answer questions regarding whether he received the bribe at the $8212 \mathrm{Club}$ but refused to answer the questions below. This was despite the fact that Schrunk's attorneys had approved the questions 
(without consulting Schrunk) thinking them fair. Schrunk agreed to answer questions about the $8212 \mathrm{Club}$, but refused to answer six of them, arguing that these first six questions were tricky. The Chair then asked the six questions and Kennedy added a seventh. They were:

1. Are you personally acquainted with Jim Elkins? Schrunk pointed out that this is a loaded question, that he only met with him once, but that he didn't know how to answer the question; personally acquainted, what does that mean?

2. In a restaurant did you get several hundred dollars from Jim Elkins? Schrunk said no, but that the question was too far afield from the issue of the $8212 \mathrm{Club}$ and therefore, he refused to answer it.

3. Did you ever take payoffs from Stan Terry? Schrunk said no, but Terry had contributed money to various causes Schrunk was involved in and, therefore, Schrunk did not know what the correct answer would be.

4. Did you receive any payoffs from any pinball operators? Again, the answer was no, except, of course, for political contributions and contributions to worthy causes.

5. While Sheriff, did you receive bootleg money through attorney Ray Kell? Schrunk said no, he did not, but that again the question was too far afield of the matter of the $8212 \mathrm{Club}$ and the alleged bribe.

6. Did you receive payoffs from any gamblers? The answer to this question was a simple no (p. 761).

7. Did you receive contributions directly or indirectly from Al Winters (sic)? The answer eventually was no (U.S. Senate Committee Hearings 1957, p. 771).

Schrunk acknowledged that he might have thanked Elkins for gifts he made to the Lower Columbia Peace Officers Club (U.S. Senate Committee Hearings 1957).

Finally, after taking a good deal of abuse from various members of the Committee, Schrunk concluded, stating that the matter of his honesty would be settled by the courts in Oregon (U.S. Senate Committee Hearings 1957). 
From the point of view of Oregon politicians, the Oregon establishment and Portland in general, the area and its people had suffered a severe national beating. The effect was very significant. Schrunk was a popular and well-received public official and now he was being discredited and humiliated in a national context. With him the entire state's reputation was in jeopardy.

Affidavits from various parties flowed to the Committee now. From Officer Bobby J. McClendon came indication that Officer Sutter did say that he had seen the bribe action at the 8212 Club; Sutter had received payoffs; Sutter had remarked that it was very difficult to convince a Grand Jury about Schrunk. McClendon's affidavit indicated that Sutter had discovered that two members of the Grand Jury were personal friends of Schrunk.

After the first Grand Jury, Lt. Bryan allegedly told Sutter that if he played his cards right, he might end up as a sergeant and that Bryan might end up as Police Chief. Later, Sutter and his wife talked about what a wonderful man Schrunk was. A few days before the election in 1956, Sutter gave a sworn statement to Schrunk favorable to Schrunk. After that, Sutter was told by Bryan to leave town for two weeks for a paid vacation. He did, after picking up his wife and kids. When Sutter found out McClendon had been called before the Grand Jury, Sutter came by to tell McClendon to be evasive. Sutter's position had thus completely changed. After McClendon testified to the Grand Jury, Bryan fround out about the Grand Jury testimony somehow, and Bryan called McClendon's superior officer who then was enraged at McClendon (U.S. Senate Committee Hearings 1957). 
Crosby Returns. Crosby was recalled as a witness. He again emphasized the he was unaware that the workers he had hired were Elkins' men. He had paid for the basement room through Maloney, and Maloney perhaps had not relayed the money. He said that he discussed the E-R with lots of people but that he never talked about anything illegal in the E-R matter. Everyone he met was interested in the Exposition-Recreation Center (U.S. Senate Committee Hearings 1957).

Crosby emphasized that he never talked to McLaughlin about taking options on the property and that he could not remember if he talked with him on the phone at all about it. He did not know McLaughlin as a gambler, but he did in fact do some betting through McLaughlin, admitting that he talked with McLaughlin about where to place bets in the Seattle area (U.S. Senate Committee Hearings 1957).

Slowly, piece by piece, Crosby ended up acknowledging that he traveled with McLaughlin to San Francisco though he suggested that their being together was a coincidence. When it was pointed out that both men's plane tickets were obtained by Teamsters official John Sweeney, and that they were paid for by Union funds, Crosby had no explanation. Crosby admitted that they took the same transportation to the hotel. He did not know, he said, that they had adjoining bedrooms (U.S. Senate Committee Hearings 1957).

Crosby said that around October of 1954 Maloney introduced himself at the Union hall. Crosby related that Leonard Givens came to him for help in getting reinstated in the Sheriff's Department. Since Givens worked for John McCourt in the District Attorney's orfice as an Investigator, Crosby asked him if he knew of Elkins giving money to McCourt's campaign. The answer was yes (U.S. Senate Committee Hearings 1957). 
Langley, in the 1980 interview, insisted that Elkins supported McCourt against him (Langley-Uris interview 1980).

Kennedy then brought up Jenkins' testimony that Elkins was active in Langley's campaign. Crosby denied having discussions with Jenkins about Langley. Crosby said that Maloney's function for the Union was essentially to help get Langley elected and some of his expenses covered by the Union.

Crosby acknowledged that around $\$ 2,300$ of Teamsters' money went to Langley's campaign. Langley was taken around and introduced to some of the men. Many Teamsters were then working for Governor Patterson's election.

While Crosby said no one told him to pay Maloney, somehow $\$ 707$ of Maloney's phone bills were paid for by the Teamsters. The bills, Crosby insisted, were accidentally paid. They should not have been (U.S. Senate Committee Hearings 1957).

Crosby said he found out that Maloney was on Elkins' payroll and that Maloney was also an undercover agent for District Attorney Langley. Maloney did come to Crosby's house a few times. Crosby denied knowing that Maloney was getting money from Elkins until he read it in the newspapers. He acknowledged that in December of 1955, in Seattle, the Teamsters were paying Maloney's bills for big Union get-togethers. At this point a check for $\$ 3,4026.57$ was presented to Crosby (U.S. Senate Committee Hearings 1957). The check included an itemization of $\$ 93.00$ for Maloney's phone bill. Much of the money was for picketing. Maloney gave the Teamsters building address as his own.

Crosby denied threatening Mayor Peterson with withdrawal of support if Peterson did not get rid of Chief of Police Purcell. Crosby said that 
Howard Morgan's statement about what he said to him was not correct (U.S. Senate Committee Hearings 1957).

Crosby denied Elkins' accusation that Elkins and Tom Sheridan of the OLCC and he ever met. He said he did not believe he had such a meeting. He did not recall the conversation. He said he believed Elkins called him once about Sheridan to help him. He said that Lt. Carl Crisp of the Portland Police Department did come to him to get help for Sheridan (U.S. Senate Committee Hearings 1957).

It developed that the Teamsters' books from mid-1954 to 1956 were missing. Crosby could not explain why these ledgers were gone. When asked why he tried to organize the pinball operators when pinball was illegal, he could not give a satisfactory answer (U.S. Senate Committee Hearings 1957).

More documents were introduced that showed a lot of Maloney's, McLaughlin's and Crosby's bills were paid for by the Teamsters.

Thomas J. Sheridan, the OLCC officer allegedly helped by the Teamsters after being accused of taking a bribe, indicated that he met with Elkins in Crosby's office and that it seemed to him that Elkins and Crosby were friends. (It is arguable that the meeting itself would have made no sense at all if the two had not been at least business associates.) He acknowledged that he had some conversations with Langley at the time the OLCC was supposedly being investigated by Langley's office. Langley was the person who instigated the meeting, calling him and having him meet at Maloney's rooms in the King Towers apartments, an odd choice for an official inquiry location (U.S. Senate Committee Hearings 1957).

The D.A. Defends Himself. William Langley began his testimony with his resume. Langley went to the Northwest College of Law and before that 
the University of Oregon. He went into law practice with his father, a well-known and respected Portland attorney, in 1938. His father was District Attorney of Multnomah County from 1930 to 1934. Langley was Assistant U.S. Attorney from 1942 to 1946 (U.S. Senate Committee Hearings 1957).

When asked when he first met Elkins, Langley took the Fifth Amendment, explaining that he was under indictment and that he could not talk without endangering himself. The Committee became alienated at this point. When asked about Maloney or Crosby, he refused to answer. He acknowledged knowing Schrunk since 1949 and indicated that Mayor Schrunk, then Sheriff, had never asked for any abatements against gambling houses. When asked if he had any interest in gambling houses or other such vice places, he took the Fifth Amendment. When asked if he had any money or involvement with Elkins in the $1940^{\prime} \mathrm{s}$, he again took the Fifth (U.S. Senate Committee Hearings 1957).

Langley started a long explanation of why he was using the Fifth Amendment and what the funtions of the Fifth Amendment are. At this point, Senator Mundt said, in response:

You embarrass yourself.

Langley said: Senator, I don't want to be disrespectful to you, but when you took an oath, you took an oath to uphold the Constitution and the Fifth Amendment is a part of the Constitution. And now I am entitled to my legal rights, and you ought not to embarrass me about it.

Senator Mundt: You embarrass youself about it, and it is very embarrassing to me as a citizen of this country to find any district attorney presently sitting in that office, hiding behind the Fifth Amendment. It is embarrassing to me to think of the people of Portland, Oregon, with a mayor who flunks a lie detector test and a district attorney hiding behind the Fifth Amendment. If I lived there, I would suggest that they pull the flags down at half-mast in public shame. So, I am embarrassed (U.S. Senate Committee Hearings 1957, p. 938). 
The Chairman, Senator McClellen, argued that the Fifth Amendment is a privilege allowed citizens, but that it is not a necessity. Mundt's statement -- that Portland ought to drop its flags in shame -- had widespread repercussions in Portland. It created a locally defensive attitude, a perception upon the part of many that Portland was under attack by outsiders (Thornton-Uris interview 1980, Baker-Uris interview 1980).

The Tapes are Played. After Langley's testimony came excerpts from the Elkins tapes. The tapes are the only outside corroborative evidence in this matter, and the Committee went to great trouble to prove their veracity, having experts from the Library of Congress testify that the tapes were undoctored. It is not within the scope of this dissertation to argue whether or not the September 1955 tapes were in some way manipulated. The experts of the time argued that such was not possible.

Elkins testified and presented the tapes. The complete tapes were never presented to the Committee as either transcripts or as tape recordings. The tape selections gave strong evidence against Maloney, McLaughlin, Langley and others. The first tape read to the Committee, called Tape 非3 of the Committee's listings (chronologically, Tape 非2), is allegedly a tape of Maloney and McLaughlin trying to figure out if they were being shortchanged by Elkins or Swede Ferguson. Leo Plotkin, "The Spy," was named, and there was clear indication that they were worried that Crosby would figure out that they were cheating him. McLaughlin accused Maloney of talking too much to John Sweeney and Clyde Crosby (U.S. Senate Committee Hearings 1957).

There were taped indications that Langley and Crosby were involved in illegal activities with Maloney, McLaughlin and Swede Ferguson (U.S. Senate Committee Hearings 1957). 
McLaughlin and Maloney apparently did not want to give the same cut as previously arranged to those above them. This is an interesting point. Throughout the tapes and the Hearings, as well as the history itself, much of the confusion, paranoia and legitimate fears of Elkins seemed to have less to do with a conspiracy of the Teamsters than of Maloney's manipulations of the situation. It was Maloney who persuaded local policitians and vice racketeers to accept him into their ranks as an aide; first, in getting Langley elected, second in accomplishing various activities. Maloney seemed to be short-changing the higher-ups, leaving the deliberate impression that James Elkins was the short-change artist. Maloney failed to relay the message to higher-ups that there was in fact little to be gained in the vice markets of Portland (U.S. Senate Comnittee Hearings 1957).

Norm Reiter, Captain of the East Precinct of the Portland Police Department (Reiter-Uris Interview 1980), said that the main reason vice activities decreased in this period was not so much Lee's changes in 1949-52 or the exposures by the Oregonian and the Oregon Journal in 1956, but that there was simply a smaller client population. The style of life had changed, and the interest in vice activity had been severely reduced. Reiter did acknowledge, however, that with both newspapers' constant front page exposes on the existence of any vice operation, it was very difficult for vice operators to stay open (Reiter-Uris interview 1980).

Public awareness and constant media spotlighting, together with the changing economic and social climate of Portland, more than any other single factor brought an end to the extensive vice operations of such men as Swede Ferguson and James Elkins, Reiter argued (Reiter-Uris Interview 1980) 
On another tape, voices alleged by Elkins to be Langley and McLaughlin discussed illegal enterprises: who would get paid how much, especially how much Tom Maloney should be paid.

In fact, the voice said to be Langley's said:

Tom gets all stirred up, and he gets unduly concerned about things. He gets out in front of the.... for the union so we should stick back and calculate about it, but if they make a change, fine and dandy, and it's the Teamsters' business, but I have the Teamsters' business, too, see. Here's the way I feel about it, Joe. The Teamsters have been good to me, but I don't want people thinking that the Teamsters own me, and yet on the other hand, I feel....

McLaughlin (indistinctly) said one word:

"... morally."

Langley replied:

Yes. Now, on the other hand, I'm a stand up guy. That's all, though. I don't want to try to dictate what they are doing, and I don't want to see them doing something that is going to hurt them. It hurts them, and then, of course, indirectly it hurts me, but you've got to.... you've got to.... you've thought it out clearly, of course ....uh, uh - Sweeney throws up his hands and says, "it's up to Pete to figure out his own way of, you know, of getting rid of Purcell."

(The Pete referred to here was said to be Mayor Peterson.)

We'll have to see what he says about that, but it still gets back over to Tom thinking it's all wrong, Joe. Tom's thinking is all wrong because he's not going for the $10 \%$ proposition. What the hell is he changing for because if he changes, that's all the more that's going to be due, Joe.... (U.S. Senate Committee Hearings 1957 , p. 953).

Langley is allegedly discussing the dividing of specific profits of illegal activities.

Langley indicated on the tapes that he wanted to close houses of prostitution. McLaughlin indicated that he wanted them open. There were also indications that John Sweeney was not anxious to have the houses of prostitution operating. 
All of the tapes at this point give indications of possible police corruption and of corruption of the Mayor. Langley said:

.... I told them that to start out with...except I put the slots in, I mean the pinballs, and they were.... It doesn't seem to be in the picture now. And the punchboards would be all right if you could get them out with just a $10 \%$ tax, I mean get the things taxed. It's a difficult thing to get accomplished. But he's already got two things going. He's got the bootleg joints, and he's got the cards (U.S. Senate Committee Hearings 1957, p. 953).

This is Langley speaking, and he is allegedly talking about the kind of money that would be made by John Sweeney. Langley indicated that the bootleg joints "have got to go," and he indicated that he perceived that Elkins was in the best shape "you've ever got him in right now." Langley agreed to give the Mayor a call about the gypsies (U.S. Senate Committee Hearings 1957, p. 953). Chief Purcell's failure to roust the gypsies would be a plausible excuse to oust Purcell.

There was reference by Langley to the Kenton problem - The 8212 Club - indicating that it had to be taken care of. How remains unclear.

Tape $\# 47$, recorded on August 22, 1955, according to Robert Kennedy, includes D.A. Langley, Joseph McLaughlin, and Tom Maloney. Persons mentioned are Attorney General Robert Thornton (described as "that screwball in Salem"); Jim Purcell, Jr. (at that time Chief of Police); Leo Plotkin (known as "The Spy"); Johnny Delaney (an underworld character in Portland, who was working as an Investigator for Attorney General Thornton); and Gordon McCreary (Chief of Hard Liquor Enforcement Division of the Oregon Liquor Control Commission) (U.S. Senate Committee Hearings 1957).

Langley allegedly said on tape:

No reason why he (Jim Purcell) couldn't. Because he can't see him on account of his dad's death. That Jim Purcell is so God 
damned hungry for money that he wouldn't even go to his dad's funeral if it meant makin' a few bucks. I'm telling you - he's money crazy - he's a money crazy guy. Well, the only worry I got - that you fellows get taken care of. If you're satisfied, why, it's all right with me.

Maloney replied: Well, I'm not satisfied.

Langley laughed: Well, you better do something then.

Maloney said: Joe's not satisfied.

Langley responded: Well, I'm not holding you back, you know that. Well, I gotta go home. You will... if anything happens to you, the Spy will call you, and you call me, okay?

And then Mclaughlin said: I probably won't be seeing you for a little while...

Langley said to Joe Mclaughlin: Well, you can't have any prostitution going, Joe, with this screwball in Salem.

McLaughlin agreed: That's right.

Langley said: You can't have them going because he...I'm telling you he's nuttier on prostitution than he (Thornton) is on this thing

McLaughlin said: That's right, and now, with this thing here, if you're not on his side where he feels as though you did... he knew, you know, that you did some... didn't do everything that you could have that he wants you to do, why, and if he draws a blank on it, why, that would be the next move.

Langley replied: He'd try to hurt me somewhat.

McLaughlin said: That's right.

Langley said: He'd be mad at me.

McLaughlin said: How long is he in there for?

Langley answered: Well, they got to defeat him, and he's in there until next year. He's in there until January 1, 1957. They'd have to defeat him next year, or it will be a nightmare for four more years.

Maloney said: $0 \mathrm{~h}$, he'll get beat. There's no chance for him.

Langley disagreed: I don't know.

Maloney said: Well, all right. I'm just telling you. I know politics. 
McLaughlin said: Maybe he's doing the screaming a little earlier, Tom. People forget.

Maloney said: You see, people forget all about him, and they think he's screwy.

Langley reasserted:

Well, he's nuttier on prostitution that he is on this so if you give him an opportunity on prostitution, he'll go. Let them run in some counties around here, and he'll focus on those. They're running, you know, in Ontario and places like that.

McLaughlin said: That's right.

Langley repeated:

So the prostitution is out, and now it's no good, and we don't want it anyway, and it's too dangerous with him. Do you see? So the only way you're going to do any good is cards, high dice. Like I told you all along, cards and book, and then if you get into pinballs and punchboard, that's all right, but that's what it amounts to. The bootleg joints... it will go if you will make it anything. That's all right. I don't see any reason to close that down now (U.S. Senate Committee Hearings 1957 , p. 957 ff.). (All transcriptions were confirmed by tapes from Oregon State Archives).

Here was a clear indication of an agreement by Langley to tolerate certain illegal enterprises that were taking place.

There was also concern that the Federal government, Uncle Sam, as it is referred to on the tapes, not become involved. This related directly to the Mann Act, which prohibits the interstate transportation of women for immoral purposes.

Elkins argued during this period that he was only pretending to be frightened of these men, but it is clear from his actions, the fact that he blew the whistle on his own operations as well as on everyone else's, that he was indeed troubled. The reference to the Kenton trouble, of course, was the 8212 Club matter. The operation of the houses of prostitution in Eastern Oregon is interesting because Bennett, the operator of the 8212 Club, got himself in trouble operating houses of prostitution in 
that area of the state. These were known to the Attorney General (Attorney General's files, Oregon State Archives).

Langley indicated that Elkins was not to be trusted, that they should be harder on him, perhaps set him up for a fall. There are several references to John Sweeney. By late August, 1955, (on Tape \#62) there were references to "The Character," Jim Elkins. This conversation involved Langley, Maloney, and McLaughlin.

Langley, who seemed anxious in several instances to uphold the law, indicated that Sheridan should close down illegal liquor operations, and Langley said:

I want to find out if there has been any bribery. Now that is the only thing that Delaney might bring in. (Delaney is the investigator for the Attorney General's office.) Delaney might claim there has been some bribery to let those bootleg joints go, see. Well, I don't see how he is going to prove it. It's only speculation on this Delaney's part. And then if the "The Character" has been giving it to McCreary or whatever his name is, so maybe we could get the Character into a mess (U.S. Senate Committee Hearings 1957, p. 961).

In other words, Langley suggested that they set up "The Character," who was allegedly Jim Elkins.

There was indication through the tapes of John Sweeney's involvement in all of this activity, or at least his awareness of it, and as well, Clyde Crosby's frequent contact with Langley. There was no absolute indication, however, that Sweeney was in on the money. There is only circumstantial evidence linking Sweeney or Crosby with the others (U.S. Senate Committee Hearings 1957).

There were discussions once more of getting rid of Jim Elkins and indications that the Chief of Police in Portland wanted everything closed "for a while" (U.S. Senate Committee Hearings 1957). 
There was a discussion of kickbacks from various gambling establishments and the dividing of that particular pie.

The tapes gave an indication of a very important social aspect of the division of vice operations in Portland. Langley indicated that he received money from "the Greek and from the Chinaman."

Langley:

"Well, now, he gave me something for the two. He gave me four bills, two of them for each one, the Chinaman and fifty bucks for some...for the Big Seven or some damn thing. And two of the Chinamen are going?

McLaughlin said: Only supposed to be one.

Langley insisted: There are two China joints going. Isn't there, Tom? Two China joints going? (U.S. Senate Committee Heraings 1957 , p. 966.)

During the Committee testimony Elkins indicated that there were two Chinese joints going, and there was only one in Chinatown and one in colored town.

Elkins said:

But the one in colored town had colored people and white people and everything running it, and $I$ knew it couldn't operate more than a week or two before they would knock it off (U.S. Senate Committee Hearings 1957, p. $970 \mathrm{ff}$.).

What E1kins was indicating was that by custom and tradition in Portland, black vice and white vice were kept separated. The minute the two merged, there would be a police response. As long as they were separated, there need not necessarily be such a reaction.

On July 23, 1956, the Oregon Journal published a series of articles by William Langley. The Journal printed Langley's version of the vice story in Langley's own words. Beginning on July 23, 1956, and running continuously through several issues of the paper, Langley gave his version of the vice story. He argued that he had been framed, that the 
tapes, in fact, were doctored. The D.A. stated that Jim Purcell, Chief of Police, was in league with Jim Elkins and was part of the attempt to frame him (Langley). The Oregon Journal, by publishing it, gave credence to this report. The paper emphasized, for example, Elkins' shady background, a matter played with much less emphasis in the Oregonian, where Elkins was initially unidentified and later only described as a bankroller for vice operations.

Langley refused to resign from office and on the 23rd said:

With arrogance of wealth and official protection which they have had in this city, they will stop at nothing to destroy anyone who has stood in their way as I have stood. Unfortunately for me and the public, they are assisted in their operation by those who should support me instead of trying to ruin me and thereby remove the greatest hindrance to their illegal operations. I have been hindered by Jim Purcell, Police Chief, at every turn. My opposition to the racketeering will be abundantly proved by my numerous letters to Jim Purcell, and the state police who will verify by their statements that on at least four occasions I urged them to come in and clean up Portland (Oregon Journal, July 23, 1956)

Senator Mundt angrily presented to the Committee the Oregon Journal article which, he said, Langley had been handing out in Washington. Mundt cited the following quote from Langley's article:

My view that Elkins has tried to use the grand jury as his bear trap for framing me is shared by at least one other public official, a man of unimpeachable character. That man is Sheriff Terry B. Schrunk. He knows that one of Elkins' hirelings has told the grand jury a vicious pack of lies about a payoff in connection with an after-hours joint in the Kenton district, which is within the city. Because of this attempted frame, Schrunk has consented to a lie detector test to show this man to be the liar that he is (Oregon Journal, July 25, 1956).

Senator Mundt then pointed out that Schrunk flunked his lie detector test in Oregon and walked out of the test in Washington. The Senate case seemed to depend on discrediting Schrunk as well as Langley. Langley, when confronted with the essay, took the Fifth Amendment. Langley 
acknowledḡed knowing John Sweeney, but refused to answer any questions about his contacts with Sweeney. He acknowledged that his Office drew up the papers for the search warrant for the tapes at Ray Clark's house, but would not say anything further under heavy questioning.

Finally, Langley asked the most significant question that he could. Anyone reading the transcriptions of the hearings of the Select Committee on Improper Activities in the Labor or Management Field (1957) must wonder as Langley did, Why weren't Brad Williams and Doug Baker of the Journal asked to testify?

This question was never adequately dealt with by the Committee except to say that there were indications that anything the Journal reporters would have to give would already have been given as testimony by others. The refusal to call them was essentially Robert Kennedy's. Basically, the Comnittee's assertions are the same as the Oregonian's case as orchestrated by Robert Kennedy. It was presented to the Committee as an absolute truth.

Langley, under further questioning, refused to state anything about the King Towers or his involvement with Sheridan, the OLCC officer. Langley refused to answer any real questions about the Teamsters' expenditures in his campaign.

Through the Teamsters' records there is an indication that by November 2, 1954, $\$ 3,160.88$ had been spent on Langley's campaign. Exhibits 1089 and 1090 indicate the total expenditure in the campaign may have been higher but that only $\$ 2,188$ came from the Teamsters (U.S. Senate Committee Hearings 1957). Kennedy presented a check (Exhibit 非5) made to the order of William Langley dated October 26, 1954, for $\$ 500$ and signed by Frank Brewster and John Sweeney, Secretary-Treasurer of the 
Teamsters. It was endorsed by William Langley. No one had filed this check as a campaign expenditure.

Investigator Alphonse Calabrese of the Senate investigative staff placed Langley at the Olympic Hotel in San Francisco and showed that his bills were paid for by the Western Conference of Teamsters in November 1954. Tom Maloney was also placed at the Olympic Hotel on the same days. On November 26 and 30 of 1954, Langley was placed at the Olympic Hotel in Seattle with his wife. His bill there also was paid by the Teamsters. All of the payments were authorized by Brewster and Sweeney. Maloney was also in Seattle at the same time. On December 16 and 17, 1955, Langley was at the Ben Franklin Hotel in Seattle, also paid for by the Teamsters, and Maloney again was there.

When asked about those meetings, Langley again took the Fifth Amendment.

Frank W. Brewster, Chairman of the Western Conference of Teamsters and Fifth Vice President of the National Brotherhood of Teamsters, took the stand.

The scope of the Teamsters ${ }^{\prime}$ power was indicated by the fact that it controlled Teamsters activity in the 11 Western states. There was a Policy Committee, a governing board of 33 members that met six times a year. There were eight Joint Councils and 246 locals.

Brewster denied having anything to do with local politics anywhere at any time. He indicated that he signed blank checks ahead of time because he traveled a lot. He emphasized the anti-Communist position of the Teamsters. He said he would have nothing to do with the Mine, Mill and Smelter Workers Union which had been painted with a red brush. He named the various charitable activities that the Teamsters had 
supported. He indicated that he started his life as a Teamster driving a dray and had always been interested because of that in horses, and subsequently, in horse racing. He had been Chairman of the Washington State Horse Racing Commission (U.S. Senate Committee Hearings 1957).

Brewster's emphasis on his anti-Communism can be seen as an attempt to prove his character since the Committee included Senator Joseph McCarthy, an avid anti-Communist. For Brewster, this attempt failed.

Evidence against the Teamsters, Brewster argued, was hearsay, "...hearsay, rumor and insidious innuendo with few exceptions from gangsters, gamblers and underworld characters." (U.S. Senate Committee Hearings 1957 , p. 999).

Brewster insisted no illegal practices had ever been engaged in in Portland to his knowledge and pointed out that Elkins was a crook with many indictments and convictions. He pointed out that Elkins' testimony was based upon alleged conversations with Maloney and McLaughlin and on supposed telephone calls which involved Brewster in discussions about rackets in Portland. Brewster said that Maloney first met him around 1939. He found some work for him at the Longacres Racetrack. He indicated that he also got Maloney a job in Seattle around 1948 or 1949. Further, Brewster said, Maloney used other people's names to promote his own schemes. (This is true. There is ample evidence that Maloney manipulated individuals through name dropping.)

Brewster indicated that he knew Mclaughlin even less than he knew Maloney. He denied knowing anything about attempts to influence elections, law enforcement rackets or liquor control. He then quite righteously defended John Sweeney, who, by the time of the Committee Hearings, was dead and could not defend himself (U.S. Senate Committee 
Hearings 1957). Brewster denied ever talking with Stan Terry or taking money from him. He indicated that a gambler named Goldbaum did set up a meeting with Elkins after Crosby told him Elkins wanted $\$ 10,000$ for fake tape recordings. He told Elkins off, he said, and threw him out of his office.

The Teamsters insisted through Crosby and Brewster that Elkins was attempting to blackmail them and had demanded $\$ 10,000$. Having warned everyone that it was unfair to pick on Sweeney, Brewster then did a turn around and indicated that Sweeney had told him about Maloney and Maloney's involvement in Portland politics and that he, Brewster, had warned Sweeney against allowing Maloney to be involved.

Brewster admitted that some books were missing from the Western Conference records (U.S. Senate Committee Hearings 1957). He believed that the reason the records were missing was because the Fire Department had asked them to clean up the basement, and they may just have thrown away the records in the rush to comply.

A $\$ 5,000$ check was shown to Brewster made out to the Public Relations Account. He could not identify what the check was for, but still argued that the records were well kept. Finally, Brewster indicated that the check was to K.C. Tanner, the attorney who represented Langley. But he was not sure; it might have been to cover Crosby's legal costs on the picketing of the Mt. Hood Cafe.

When Brewster was asked whether the locals were consulted on political matters, he indicated that he did not know the answer to that, but admitted that the Teamsters did spend money on Republican Patterson's successful election as Governor of Oregon. And, Brewster indicated, they did spend money on political campaigns, arguing that the chief 
expenditures were to educate working people about working people's issues (U.S. Senate Committee Hearings 1957).

At this point, Senator Richard Neuberger (Democrat, Oregon), appeared before the Committee. He indicated that legal parimutuel betting on dogs was a major problem in Oregon. He suggested that it was absurd to complain about a ten cent expenditure on pinball when thousands of dollars could be thrown away on parimutuel betting. He indicated that Portland had a courageous and good Mayor in Dorothy McCullough Lee, who was teased and ridiculed and called "Dottie Do-Good." He said that it was even suggested by various businessmen that a viceless town might be bad for business. This is interesting because it confirms E. Kimbark MacColl's (1978) mention that the business community on the whole was not supportive of Dorothy Lee's mayorship (U.S. Senate Committee Hearings 1957).

Senator Neuberger said that Portland was a wonderful town. He objected to the smearing of deceased Governor Patterson and pointed out that many people not being heard by the Committee would dispute what the Committee was hearing. And, he argued, the Committee should be taking contradictory evidence. Schrunk in this case was being unfairly treated. He pointed out that corruption had always been a problem in American cities. He thought it completely unfair to smear Portland and to suggest that Portland lower its flags to half-mast (U.S. Senate Committee Hearings 1957).

It developed that Nathan Shefferman, a well-known gambler according to testimony elicited from Brewster, was getting money for public relations from the Teamsters. Brewster had also been allowing checks to go out paying for the transportation of horse jockeys (U.S. Senate Committee Hearings 1957). 
The aspect of the Hearings of the U.S. Senate Select Committee on Improper Activities in the Labor or Management Field (1957) concerned with Portland, Oregon, virtually ended at this point. The rest of the material in these Hearings was concerned largely with activities of the Teamsters Union nationally and in other cities.

In evaluating these Hearings, the historian must keep in mind a number of things. First, the Hearings were derived originally from the testimony and stories developed by the Oregonian reporters Turner and Lambert through information given to them by James Elkins. Elkins did have a vested interest in all of these matters. Second, stories developed by the Oregon Journal are not in any way dealt with by the Committee, except in terms of manipulations done by Oregon Journal reporter Brad Williams. Third, the Committee was looking for a sensational way to excite public concern against alleged abuses by organized labor.

The Journal's View.

As has been mentioned the vice probe first broke into the public print on April 19, 1956. A 1980 interview with William Lambert indicated that the Oregon Journal, to its credit, quickly caught up on all the salient facts in the case, and in fact, was first to break the story of Clyde Crosby's alleged involvement in a plan to profit by the purchase of options on iomes located in the path of the planned Exposition-Recreation (Memorial Coliseum) Center.

Almost one year later, beginning on April 8, 1957, the Oregon Journal summarized its differences with the Oregonian on the question of what really happened in 1955 and 1956 in Portland's vice politics. The 
Journal put a so-called "truth squad" on the case. Composed of various reporters at various times, the leading personages were: Doug Baker, then and today a columnist for the Oregon Journal; Brad Williams, presently a public relations person for a major airline; and Rolla Crick, another Journal reporter.

The Journal's response to the initial publication of Elkins' story and the subsequent articles, according to Baker, in a 1980 interview, was caused by their failure to pick up the story at its outset:

We were left in the starting blocks unnecessarily because one of our reporters (Rolla Crick) had stumbled onto this story before the morning paper did or at the same time, but he couldn't get anyone to take him seriously. He heard things at Dan Tomes' Western Club, once called The Press Club.

He had quite a bit of it laid out for him, but whoever he told here at the Journal, whatever executive he told at the Journal, didn't show much interest in it, and it sort of just languished. And all of a sudden they, (the Oregonian) came out, boom, you know, big banners, long...transcripts of these tapes, accusations against the district attorney, the mayor, the attorney general, you know, the whole thing, and the Teamster thing, all that.

And of course we're writing second day copy, you know. All we were doing is wallowing in it, and I think our executives very quickly saw that we would have to get into this thing, and so people like me and Brad Williams were put on the story. But even then the Journal's interest was half-hearted. The Journal's real interest in this story began when this "runaway grand jury;" (the special grand jury under Ralph Wycoff and Arthur Kaplan) "returned indictments naming a great many Journal people, including the publisher, as co-conspirators. That, of course, galvanized the Journal into a lot of investigative action. (Baker-Uris interview 1980)

Again, it must be emphasized that the Oregon Journal was a locallyowned paper with local financial backing at this time, and due to the actions of E. B. McNaughton regarding the estate of the original Oregonian founders, the Oregonian was, at the time, in the hands of the Newhouse newspaper chain. 
In a series called "Let's Look at the Facts," a set of four editorials begun on April 8, 1957, the Oregon Journal responded to the Oregonian's presentation and basicaily to the Senate presentation of the vice probe facts. They began with a criticism of the April 8, 1957, Time Magazine, pointing out that the Time article attacked the Oregon Journal unfairly, and argued that many of the facts in the article were inaccurate. This editorial went on to commend the Oregonian: "It has exposed evidence of questionable ties between Teamsters officials and racketeers, but it has glossed over equally dangerous corruption involving home-town racketeers." (Oregon Journal, April 8, 1957)

Thus, the Journal suggested that while there was indeed a plot to take over local vice activities by individuals associated with the Teamsters Union, there nevertheless was at the same time a continuing and ongoing plot among public officials and vice lords to operate illegally within the city of Portland, Oregon. The Journal attacked District Attorney William Langley, demanding of him a full explanation for his behavior.

The Journal insisted that the Oregonian had failed to explain that Jim Elkins (called by the Oregon Journal "Big Jim") was involved in corruption within the Portland Police Department and possibly with the Office of Mayor Fred L. Peterson himself. As the paper said:

For months it, the Oregonian, turned a blind eye to corruption in Portland's Police Department which could have been embarrassing to Elkins and to the Oregonian's candidate for mayor, Fred L. Peterson (Journal, April 8, 1957).

The Oregonian, the Journal wrote, ignored the story reported by the Journal that one of the Oregonian's own reporters was threatened by Elkins with being dumped in the Willamette River because he dared "investigate payoffs in the police bureau." 
This article referred to a story based on information obtained by James Burr Miller, the Oregonian's police reporter. A piece appeared on August 3, 1956, with headline "Police reporter under payoff," subhead "Honest patrolman comes to newsman to collect evidence for grand jury." The story asserted that a patrolman, Jack F. Olsen, became angry when given payoffs through the police department.

Miller took his story of attempted bribes of 0lsen to the editors. Olsen apparentely shared money with policemen in an attempt to get evidence against the bribers within the Police Department. Olsen was approached by an East Precinct police sergeant who indicated that there was a little deal going on at a Chinese place on North Williams Avenue and Russell. 01sen was told there would be "smile money" if he stayed away from the place. When Olsen expressed anger to his partner, his partner told him that it would be worth $\$ 50$ a month and not to even talk to his wife about it. When 0lsen suggested he should go to the Chief of Police about the matter, his partner supposedly said, "Who do you think is running the thing?" The Chief of Police at that time was Jim Purcell.

01sen apparently recorded the numbers of the bills that he received and marked his initials on them. Eventually, he took the story of the money bribe to Miller. This information is supported by the Oregonian story as well as the Journal.

Olsen reported that he shared the money with other policemen between September 8, 1955, and April 10, 1956. He said he was paid either by a sergeant, a patrolman or the vice operators themselves. Olsen went before a Grand Jury, told his story and gave that body $\$ 158.50$ in marked money to substantiate the charge. Most of the money, according to 01sen, came to him from the Chinese and black gambling joints in the Williams Avenue area. 
In an editorial in the series "Let's look at the facts," published on April 9, 1957, the Journal emphasized that some of the money came from a woman named Sunny Martin (a prostitute, according to the Journal), who shared a duplex with Elkins' man Ray Clark and his wife Jerry Rogers (Oregon Journal. April 9, 1957).

When Miller took his story to the Oregonian editors without identifying 0lsen, they suggested that he go to the District Attorney, William Langley. Langley took no action. However, after the Grand Jury had indicted seven officers on perjury charges arising out of the bribery evidence presented through the efforts of Officer 01sen and Miller, the Oregonian ran its story on October 3, 1956.

The Journal argued in an editorial of April 9, 1957 that Miller's full role and involvement in the story and in the investigation was never brought to light by the Oregonian. It pointed out that Elkins' involvement in an attempt to bribe and then threaten Miller, the police reporter, was never metioned in the Oregonian. On August 26, 1956, the Journal disclosed that in October of 1955, a police captain approached Miller and asked him to join the International Footprint Association, a social club of policemen and their friends. This was a few weeks after Miller and 0lsen had got together with the payoff story. Miller said he was not sure he wanted to join. A police capatin assured him he could find a sponsor to cover membership dues and expenses. Miller apparently was curious about the identity of the sponsor and agreed to a rendezvous with his unknown benefactor. The unnamed police captain took Miller to a downtown restaurant and introduced him to Jim Elkins. The captain then left Miller, according to the Journal story, and the racketeer and Miller conversed alone. 
According to the Journal, Elkins talked in generalities and then told Miller he understood the Oregonian reporter was interested in joining the Footprinters. A large wad of money was shoved across the table to Miller. Miller refused to accept it. As he refused it, Elkins, to quote the words of the Oregon Journal, "turned off the smile and switched to threats." (April 8, 1957.) He talked vaguely but pointedly of people disappearing, being dumped in the Willamette River. He threatened Miller's family.

Miller told the story of his dealings with Elkins not only to his editors but apparently to the Grand Jury, to Attorney General Robert Y. Thornton and to a number of state policemen. On August 5, 1956, Miller explained in a bylined article in the Oregonian how he and Patrolman Olsen gathered the evidence of bribery. But the article made no reference to his meeting with Elkins, according to the Journal. This is confirmed by an examination of the article. The Oregonian did indeed fail to tell of Elkins' threat, if such a threat actually occurred as asserted by the Journal.

On August 28, 1956, Captain Robert Mariels, then the Commander of the Portland Police Department's North Precinct, told the Journal that he was the police captain who set up the meeting between Elkins and Miller. Mariels insisted that he was flabbergasted by the report that Elkins had attempted to bribe Miller and then threatened him. Mariels said he set up the meeting because Miller told him he wanted background information for a book he was writing.

Miller denied Mariel's version of the story, according to the Journal. Apparently, said the Journal, according to friends of Miller, he took the threat quite seriously and requested protection from the Beaverton Police Department for his family and home. 
Chief Purcell (by the time of this Oregon Journal editorial, no longer Chief of Police) ordered an investigation by his Deputy Chief, Gene Ferguson. Ferguson apparently filed an inconclusive report with Purcell, and Purcell, in the week of April 2, according to the Journal, informed the Journal that the report had been passed to former Mayor Fred Peterson and that that, apparently, was as far as it got.

Miller, according to the Journal editorial, was no longer a police reporter. He was at that time working on the farm market beat.

Meanwhile, said the Journal, the Oregonian's editorials kept changing their position on Mayor Peterson's regime. At first - and this is verified by the editorials in the Oregonian - the police were supposedly successfully blocking the attempts of the outside vice combine to gain power. This was in April of 1956. By May of 1956, the Oregonian's editorials were less certain, and it was suggested that the combine's efforts were only to some extent frustrated by the city police. By June 6 , the paper was suggesting that Portland was singularly free from organized vice. But in early August, after the Grand Jury began to return its indictments, allegations linking several Portland policemen to the practice of payoffs for protection of illegal joints were made.

Chief Purcell was also indicted on charges of incompetence, delinquency and malfeasance. At that point, the paper informed people that the Oregonian was aware of the charges and that Miller had been working on substantiation of those charges and was instrumental in the success of the indictments.

But by October 26, 1956, the Oregonian suggested the facts against Purcell were obscure, and in that same issue of the paper, supported Fred L. Peterson for Mayor. Peterson had refused to suspend Purcell after his indictment by the Grand Jury. 
On May 1, two weeks after the furor had started, an Oregonian editorial said that District Attorney Langley and his staff should be "barred from any appearance before the new Grand Jury except as subpoenaed as witnesses." (Oregonian, May 1, 1956.) It even went on to suggest that Langley should resign.

The Oregon Journal contrasted the Oregonian's attitudes toward Langley with their attitudes toward Mayor Fred Peterson and Police Chief Jim Purcell. Finally, in August, according to the Journal and substantiated by an editorial of August 13 in the Oregonian, the Oregonian decided that the "unprejudicial suspension of both Mr. Langley and Chief Purcell, pending the judgment of the trial court" should be carried out.

However, on March 30, 1957, in commenting on the indictment of Mayor Terry D. Schrunk, the Oregonian forgot its arguments about unprejudicial suspension and suggested that Schrunk should resign as well.

The Journal emphasized in its editorial of April 9, 1957, that it had always insisted that all of these individuals should have resigned as soon as they faced indictment.

Turning now to the first of these "Let's look at the facts" editorials in the April 8, 1957 Journal, the Journal pointed out Jim Elkins' inconsistencies in testimony. These editorials were attacks upon the Oregonian. In the course of these attacks, however, the Journal emphasized that Jim Elkins was arrested and convicted for engaging in a gun battle during an attempted robbery in Globe, Arizona, and that Elkins was also convicted for receiving narcotics. The Journal said also that he was more than simply the bankroller of illegal operations, that he was actively involved in vice activities in Portland, and was dangerous. Further, the Journal pointed out that the Grand Jury, under Attorney 
General Thornton, indicted Elkins more often than any other person involved in the vice probes, and that the charges included gambling, extortion and receiving the earnings of prostitutes.

Elkins, in explanation both in the Oregonian and to the Senate Committee, insisted that one of the major motivations in his going to the Oregonian reporters was his dislike of prostitution and his anxiety not to have prostitution become part of his operation.

Elkins did have close involvements with Ray Clark and his wife Jerry Rogers and other madams. He had knowledge of and involvement with other prostitutes and madams in the Portland area. There was a tight involvement of prostitution with other forms of vice activity, historically, in Portland.

Another explanation for Elkins' motives exists which makes sense and gives consistency to Elkins' approach. Elkins feared, given the tape recordings that he had secured, that he was being cut out of the action. According to the tapes, he was in danger of losing not only control of vice activity, but of going to jail as well. Ex-District Attorney Langley reported that he intended to break Elkins' power (Langley-Uris interview 1980).

The Journal of April 8, 1957, argued that it had always demanded a full investigation of the vice conspiracy. The April 8, 1957, Time Magazine article was entirely inaccurate in several instances not relevant to this particular study. Time, on March 18, 1957, asserted that:

Last week Elkins and some corroborating witnesses told how Teamsters' representatives, stymied in their original efforts to open the city to vice, simply took over the municipal government (p. 25). 
Elkins did not say this, and Time Magazine was in error as the Journal editorial pointed out.

In dealing with the incident of the attempt to discredit Elkins initiated by the Oregon Journal through a raid on May 17, 1956, on the home of Ray Clark and his wife, Jerry Rogers, the Journal justified its actions in terms of their interest in finding out what was really going on.

In the second of these editorials, "Let's look at the facts," on April 9, 1957, the issue of Miller and Olsen's attempts to uncover the bribery of police officers and the "smile money" payoffs is detailed. In the third of these editorials on April 10, 1957, in the Journal, there is a careful discussion of the recording sessions and tapings and the securing of the search warrant to gain the tapes from the home of Ray Clark.

The Ray Clark Raid. The evidence of the wire tap itself was gained through this incident. It was to become notorious in the Portland vice probe. District Attorney Langley was able to obtain a search warrant on May 17, 1956, the eve of the primary election. Ray Clark had been Police Chief for the town of St. Helens and had also been a Portland policeman. He was a business associate of Elkins and an electronics whiz. Clark's wife, Jerry Rogers, was a well-known madam in Portland.

Based on a phone conversation between Ellsworth Herder, St. Helens Police Chief and Journal reporter Brad Williams, with Langley listening in, Langley drew up a warrant which he presented to Judge John Mears based on allegations that Clark had pornographic materials in his house. Under pressure, Judge Mears signed the warrant believing it was valid. He sent Detective Minielly and others to execute it. The raid took place on the eve of the primary election of May 18, 1956. 
Doug Baker and Brad Williams of the Journal went with the deputies to Clark's home to seize the allegedly pornographic materials. What was found there were some party records and 26 slot machines. While the raid was in progress, Jerry Rogers was sitting on a hassock.

Baker described in a 1980 interview both his and Brad Williams' active participation in the search of Ray Clark's house. He said:

He (Williams) went around opening drawers and rifling through shelves.... but myself being a little bit more mindful of the ethics of newspaper men....I merely stood in the living room (Baker-Uris interview 1980).

But, Baker said, he noticed a hassock which seemed very protected by Jerry Clark, and he pointed the hassock out to the Sheriff's men. In the hassock were the tapes of Elkins' wiretaps which were then illegally seized (Baker-Uris interview 1980).

Shortly thereafter, Baker remembers, Williams entertained the State Police and Teamster Clyde Crosby with the tapes' contents .

When I got there, he (Crosby) was all set up with all his expensive recording equipment. ....See, I'm a little more ethical type of reporter than Brad. Brad's a derring-doer. He's a Front Page type reporter. I'm kind of a different school. I was shocked, but Brad was one of these irrepressible guys. You couldn't do anything with him, you know. I said, "My God, Brad, you can't let Clyde copy these tapes," and he'd say, "Oh, it's all right." What are you going to do? (BakerUris interview 1980).

While the raid was still going on, an Oregonian reporter, William Lambert, was tipped off and rushed to Clark's house. He arrived as the raid was ending and began to phone his story in. He was threatened by Brad Williams according to his taped interview of 1979 , for attempting to be a part of the action (Lambert-Uris interview 1979).

Within two days, Judge Mears decided that the search warrant was obtained under false pretenses and inadequate testimony. Meanwhile, 
copies of the tapes were made by Schrunk and apparently were played for technicians of the Oregon Journal and the Journal-owned radio station KPOJ. They made copies for, among others, the Oregon State Police. Oddly, the tapes were kept in the vault of the Oregon Journal, which was thought for some reason to be safer, according to the Mayor and one-time Sheriff Terry Schrunk, than the Sheriff's office safe (U.S. Senate Committee Hearings 1957). Apparently, Clyde Crosby heard the tapes without Schrunk's permission while Journal reporter Brad Williams was playing the tapes for Oregon State Police at Williams' house. It is probable that Langley heard the tapes.

When Judge Mears ruled the affidavit on which the search warrant was based as improper, he did not return the tapes to Clark, as would normally be the case. Instead, he ordered them turned over to Thornton. Thornton gave them to the State Police, who put them in a safe deposit box where they were seized by the F.B.I. after Federal Judge Claude McCulloch (an old Langley family friend) ordered an investigation by the Federal Grand Jury of the charges of wire tapping.

The raid on Clark's house was treated very differently by the two papers. From the Senate hearing materials and, by inference from the way the articles were written, it becomes clear that the Oregon Journal had a great stake in the success of the raid. Whatever else was happening, the raid was manipulated into existence at the instigation and in the interests of the Journal. That it was helpful to Langley is another issue entirely.

The Journal, which lacked sensational material like the tapes made by Elkins, now had tapes of its own. With this change, the relations between the two papers became more intensely rivalrous. 
The Elkins wire tap bust is a very interesting matter in and of itself. The tapes were not allowed as admissible evidence in the Oregon State case but Langley was able to persuade Federal Judge Claude McCulloch to bring to the Federal Grand Jury nine violations of federal wire tap ordinances. Langley, in a 1980 interview, confirmed that he influenced the federal judiciary to move against Elkins (Raplan-Uris interview 1979; Langley-Uris interview 1980).

Elkins was vulnerable. At that time the Silver Platter Doctrine was law. This rule allowed illegally gathered evidence, given legally to a federal agency, to be used in federal court. Elkins eventually carried his case to the Supreme Court and won. The Silver Platter Doctrine is no more (Elkins v. United States, June 28, 1960). Elkins did away with an anomoly in law which allowed illegal state procedures to be admissible legally in federal courts.

William Lambert indicated (Lambert-Uris interview 1980) that he got news of the raid through a contact who called him from the Oregonian office, but not directly, he said, from Jim Elkins. The Journal, by innuendo, suggested that Elkins immediately contacted Lambert, and Lambert rushed to the scene of the raid in southeast Portland. When the raid and seizure were determined to be based on a faulty affidavit prepared by District Attorney Langley, the Journal insisted that the Oregonian's attorney had joined forces with Clark's lawyer in an effort to take the evidence from Langley. Deputy District Attorney Oscar Howlitt attempted to play some of the obscene recordings in an effort to prove the validity of the warrant, but Judge Mears, apparently after a conference with Attorney General Thornton, refused to allow this. 
The Oregon Journal in its April 10, 1957 editorial, argued that Schrunk was courageous in allowing the Journal's reporters to hear the copies of the seized wire taps and recordings. Five Journal and KPOJ employees, by the Journal's own admission, were present when the tapes were played for the first time on the early morning of May 18, 1956.

It was unusual for a Sheriff to allow reporters to hear, prior to trial, any evidence that would be admissible in a court of law.

The Journal said that it took steps to put the copies of the Clark tapes and the information which they contained into the hands of the State Police, who were cooperating with Attorney General Thornton in the vice investigation. Within hours of the raid, the Journal said, it permitted State Police to play copies of the tapes in its possession. Schrunk had indicated that the tapes would be turned over to Thornton as soon as they had made a copy.

The Journal, in an attempt to justify its actions, pointed out that their reporter Brad Williams made a spur of the moment decision to permit Clyde Crosby, at Crosby's request, to attend the meeting at Brad Williams' home in which the tapes were being played for It. Claude Cross of the State Police. Crosby, the Journal editorial admitted, made copies of the tapes, which was done without the knowledge of the Journal management. Williams' actions, the Journal said, were open actions, however, and the copies were made in Lt. Cross' presence. No one was hiding the fact that the tapes were being made, they emphasized (Oregon Journal, April 10, 1957).

Among the Miniphone recorder reels found in Clark's basement were two official Portland Police Department recordings - one a recording of Chief Purcell's telephone conversations with H.G. Fod Maison, the 
Superintendent of State Police. Maison apparently did not know that he was being taped. For months the Journal demanded explanations why these tapes were in Ray Clark's possession.

In the fall of 1956, ex-mayor Fred Peterson offered an explanation of the Miniphone recorder's presence in the Clark home. Peterson put in the City Council minutes a report from then Police Chief Purcell saying that the former Chief had recorded a telephone call to State Police head Fod Maison upon advice of his attorney. The call was prompted by complaints from Portland police officers that they were being hassled by State Police in connection with the vice investigation. (Purcell and 8 of his police officers were later indicted.) The Chief indicated that he made the recordings of his call on May 12, 1956. He stated that the Oregonian reporter Wallace Turner had requested the loan of a minirecorder in February and that Purcell had directed Sergeant Ralph O'Hara to give him the machine. When Purcell needed the machine in May, he learned that it had been delivered to Clark's home on Turner's instruction. The Miniphone was picked up by Sergeant 0'Hara and was returned to Chief Purcell, but the original recordings that Purcell had made were by error left in Clark's home.

The Journal and the Schrunk Trial. Tom Maloney, who had disappeared shortly after the vice story broke in the Oregonian, was found by Journal reporter Brad Williams in Washington State. The question arose of how the Journal found Maloney, if it were not in cahoots with him. The Journal's explanation was that the reporter worked very hard to discover his whereabouts and that simple, hard perseverance succeeded where police and Oregonian activity had failed (Oregon Journal, April 14, 1957). 
The Oregon Journal continued its "Let's look at the facts" series in a fourth editorial on April 14, 1957. It dealt extensively with the allegations that Terry Schrunk had accepted a bribe from Clifford 0 . (Jimny) Bennett, operator of the $8212 \mathrm{Club}$ on North Denver Avenue in Portland in the pre-dawn hours of September 11, 1955. The accusations centered around several questions which the Journal then answered:

1. Why did not Schrunk arrest Bennett at the raid? (Schrunk told the Senate Committee, reaffirmed at his trial, and was believed by the jury, that there was no actual evidence of gambling, drinking or money changing hands in the private club.)

2. Why did several city policemen and several other witnesses see Schrunk pick up something Bennett had left behind a telephone pole? (Schrunk had denied this, and later the evidence of the various policemen was put into disrepute when several of them changed their stories, particularly Officer Sutter.)

3. Why did a lie detector test in Oregon indicate that Schrunk had lied?

4. And why did he balk in taking the lie detector test in Washington? (Schrunk had argued that the lie detector test in Oregon and Washington D.C. were manipulated against him.)

Critics of Schrunk saw his activities as part of a plot to extract bribes and to support illegal operations. They argued that the raid on the illegal joint inside the city was essentially an attempt by Schrunk to discredit the city police department, which they argued had been highly successful in opposing the Teamster-gangster alliance.

The Journal pointed out that the Oregonian supported Peterson as mayor against Schrunk. The Journal implied that Peterson had been 
involved in bribery. But because he was a Republican, and the Oregonian was a Republican paper, they continued to support him (Oregon Journal, April 14, 1957).

Schrunk's defenders at the Journal saw the $\$ 500$ bribe incident in a very different light. On April 14, 1957 the Journal argued that it made no sense that Schrunk would go out early in the morning to get money from an underworld figure when, in fact, a telephone call would have sufficed. Further, the Journal asked rhetorically: Why would Bennett pay a bribe when his place was going to be shut down anyway? Why would he avoid arrest with a $\$ 500$ bribe when the fine would be that amount at the most? Why did Schrunk call the city police to pick up a bicycle at the scene? Why, in other words, did he expose himself to the full view of policemen, Sheriff's officers and passersby to accept a bribe when there were far more discreet ways? And finally, why did Portland policemen who said they saw Schrunk take the bribe not immediately report it to their superiors since evidence of Schrunk's taking a bribe would have been most useful to Peterson and Purcell in their campaign to maintain power? Schrunk denied taking the bribe and offered to take the Senate lie detector test, balking only at questions outside of the bribe issue. Schrunk had been indicted and found innocent of perjury in connection with lying to the Grand Jury about the alleged bribe. His trial took place at the time that he was Mayor and was popular.

The Journal argued that Schrunk's general reputation for honesty was well known and that reform Mayor Dorothy McCullough Lee used Schrunk as one of those at her right-hand side cleaning up vice in Portland. The Journal pointed out that the question of Schrunk's honesty was never raised until he had decided to challenge Peterson for the mayorship. 
There were numerous instances cited in 1949 and 1950 of Schrunk's anger at being offered bribes, as reported in the newspapers of that time, said the Journal editorial.

Continuing its analysis, the April 14, 1957 Journal editorial argued that according to Schrunk, the raid of September 11, 1955 was a spur of the moment response. Schrunk had believed that the 8212 Club had been closed. When he discovered that it was open while on his way home early one morning, he decided to send two officers into the club to see if they could gain evidence for an arrest.

There were 7 witnesses who suggested Schrunk's guilt: Elkins, indicating the shortage in the bankroll; Laura Stone, the bookkeeper for Elkins, who operated at the $8212 \mathrm{Club}$; John W. Vance, an Elkins' employee and an ex-convict who agreed apparently with Bennett that the $\$ 500$ bribe was cheaper than a larger loss of money; Mrs. Virginia Jenkins, hatcheck girl and wife of an Elkins employee, who mentioned the manila envelope; City Patrolman Merle L. Tiedeman, who said he saw Schrunk and Bennett both stop by the telephone pole; Lowell Amundson, Tiedeman's partner, who described Bennett bending down and Schrunk appearing shortly thereafter and bending down at the same spot; and Frank Daniels, bartender who came to the club to apply for a job.

At the perjury trial, the officers' testimony and Elkins' lies about his narcotics record would contradict each other. In several instances the policemen's testimony had changed from the version of the Oregonian and the U.S. Senate Select Comnittee on Improper Activities in the Labor or Management Field (1957).

By March 8, 1957, the Oregon Journal said Officer Sutter, one of those initially accusing Schrunk, had changed his story about Schrunk's 
bribe. Bennett, who had refused to appear before the Senate Committee, stated later to the Journal that he would have appeared at the Hearings and told a different story if he had not been afraid. (Editorial, April 14, 1957, the Oregon Journal.) He felt that with 7 witnesses disagreeing with him, he would be charged with perjury, and instead, went with the lesser charge of refusing to answer the questions of the Committee - contempt of Congress. Bennett said there were further witnesses that would support his story but had refused to name them.

On June 23, 1957, court reporter Jean Watkins transcribed a recording secretly made in a car of conversations allegedly among Clifford Bennett, 8212 Club operator, Frank Daniels, bartender-witness and Floyd Johnson. The transcription of the secret recording was made at radio station $K W J J$. The recorded transcript clearly indicated that there was a plot involving Elkins' employees to perjure themselves in an effort to discredit Terry Schrunk (Bennett, Daniels and Johnson, Attorney General's Files, Oregon State Archives, June 23, 1957, accession number 61-67)

The transcript stands in direct contradiction to a tape of Bennett, Turner, Lambert, Elkins and Clark made at the reporter's hotel room in the Hungerford Hotel on May 9, 1956. The tape was made without Bennett's knowledge. In this transcription, Bennett tells of bribing Mayor Schrunk while Schrunk was Sheriff (Bennett, Turner, Elkins and Clark, Oregon State Archives, May 9, 1956, accession number 61-67).

The Journal (April 14, 1957) stated that Bennett's story in every detail had been checked out and made sense. That, for example, Elkins held the mortgage on the home of Virginia Jenkins, the hatcheck girl who testified that Bennett needed a manila envelope. Her motives would be suspect, the Journal insisted. 
A Kenton barber, Clarence Nichols, said that he overheard two men in his shop, while one was getting a haircut saying, "He's (Schrunk) got to be got rid of, there's talk of him running for Mayor. You can't get to him; you can't buy him. He's got to be hit with a frame so hard he'1l never forget it." Nichols, according to the Journal (April 14, 1957) also claimed that city police knew that the 8212 Club was operating and did nothing to close it. Once, he said, a car with Seattle license plates and containing a roulette wheel and other gambling paraphernalia was parked near the club for three days and did not even get a ticket. Police officers pushed it to another parking spot, rather than tow it away.

From February 27 to March 10, 1956, Officer Sutter testified to the Senate Committee that he had watched Schrunk's home to report on his movements to the police department should Schrunk initiate any surprise raids (U.S. Senate Committee Hearings 1957).

Officer Iindholm said that he was under heavy pressure by both Jim Purcell, Chief of Police, and Wallace Turner and William Lambert of the Oregonian to recall events in the same way that Tiedeman and Amundson had. Purcell had questioned him for 3 hours and then had sent him to talk to Turner and Lambert. They all, he said, told him it would sound funny if he ever tried to testify in court that he could not remember the episode. Lindholm was never called before the Senate Committee, the Journal (April 14, 1957) pointed out.

A Journal editorial of October 1, 1957 labeled Elkins as a sociopath who had taken the Fifth Amendment 51 times in the course of the Maloney trial (Oregon Journal. September 30, 1957). It pointed out that he had been involved in safe burglary, drug activity, etc. 
In July of 1957 there were 65 indictments. Langley faced 7, including: conspiracy, malfeasance, bribe taking and the improper use of a search warrant. Elkins at that time faced 11 charges. Crosby faced 6 , including: false swearing, wire tapping and his involvement in the E-R conspiracy among others. Several police officers were involved in accusations of false swearing.

The costs of the vice probe were continuously emphasized by the Journal. By September 1957 , costs had reached $\$ 120,000 ; 64$ of the Grand Jury indictments had been dismissed; there had been three acquittals, only one conviction, 2 guilty pleas, and total fines of $\$ 350$, all of which were pending (Journal, September 28, 1957).

Mayor Terry Schrunk's Perjury Trial. By the time of the trial witnesses had changed their stories; Lt. William Brian said Nordon Nieman saw chips at the 8212 Club. Nieman denied under oath that he had. Brian said that officer Tiedeman never mentioned the bribe at all to him until it came up in the Oregonian and at the Senate Hearings.

During the time of the trial, the Journal was constantly editorializing against Arthur Kaplan, the most vigorous of the prosecutors for the State of Oregon. Kaplan's lengthy Grand Jury session with its huge number of indictments was called "Kaplan's capers" by the Journal and by Thornton in a 1980 interview (Thornton-Uris interview 1980).

Kaplan, in a 1979 interview, described how he attempted to return to Oregon to practice law after leaving the State Attorney General's office to work for the U.S. Senate Select Committee on Improper Activities in the Labor or Management Field (1957). He said he found that he could not find anyone to rent him office space, and he was given the cold shoulder throughout the business and law community of Portland. In fact, Kaplan 
indicated that much of the Jewish community was most annoyed at him, feeling that he had caused negative attention to be brought to improper activity by some Jews in the community (Kaplan-Uris interview 1979).

Robert Rennedy was brought in as a witness at Schrunk's trial. He seemed very close to the prosecution, to Ralph Wycoff, to Turner and Lambert of the Oregonian and to Jim Elkins. Kennedy stepped down from the witness stand and shook hands with the judge. This must have had an interesting effect on the jury at the time (Oregonian, June 28, 1957).

The two county policemen involved in the trial, Ed Grohs and Gordon Newmann, indicated there was no envelope and no gambling visible although they had apparently testified to the opposite to the investigators from the Prosecutor's office before the trial. Cliff Alterman, a partner of Ray Kell (Schrunk's campaign manager) and later of Ted Runstein's, stated in the Journal (July 24, 1957) that Oregonian reporters were often with ex-policemen, Elkins' workers and Ray Clark.

Frank Daniels told Alterman to check Room 305 of the Hungerford Hotel. There they found Oregonian reporters with Ray Clark. The explanation by the Oregonian's publisher Frye was that Clark was hired to transcribe tapes. The continued close association of associates of Elkins with the Oregonian staff cast serious doubt on the validity of that paper's position (Oregon Journal, July 24, 1957).

One-time Oregonian reporter William Lambert repeatedly insisted that Elkins, whatever his crime record may have been, was an honest man engaged in activity born out of desperation and fear (Lambert-Uris interview 1979).

Schrunk is Found Innocent and Elkins Falls. On Saturday, June 29, 1957, Terry Schrunk, then Mayor of Portland, after two hours of deliberation by the jury, was found innocent of perjury. 
On October 28, 1964 Elkins was found guilty and convicted of a narcotics charge. The information for this charge, incidentally, was gathered by Dick Bogle, then a policeman, now a television journalist for KATU, Channel 2. Later Elkins died in rather mysterious circumstances at the age of 67 on August 2, 1972. Elkins was nearing the town of Globe, Arizona, where he had been arrested long ago and convicted for exchanging gunshots with policemen in the course of a burglary. According to the story in the Journal and the Oregonian (August 2, 1972), he suffered a heart attack, and his car crashed into a utility pole.

(It is interesting to note that Captain Norm Reiter of the Portland Police Department speculated in a 1980 interview that Elkins may not have been the man in the car, that Elkins disappeared and another body was substituted for his. There is no evidence to substantiate this, but the legend of Jim Elkins lives on in the mind of at least one Captain of the East Precinct of the Portland Police Department. Reiter-Uris interview 1980.)

Blackmail and Elkins' Motives. At the time of the vice scandal, District Attorney Langley insisted that the tapes played by Jim Elkins to the Oregonian reporters and to the U.S. Senate Select Committee on Improper Activities in the Labor or Management Field (1957) were faked. Experts presented by the Senate Committee (U.S. Senate Committee Hearings 1957) insisted they were genuine. Both then Attorney General Thornton (presently sitting on the Oregon Court of Appeals) and William Lambert, then a reporter for the Oregonian, in interviews conducted in 1979 and 1980, respectively, insist they were genuine. Both cite the unbroken background noises, the overlapping exchanges and poor quality of sound as support for the authenticity of the tapes. Doug Baker, then 
and now a reporter for the Oregon Journal, despite his distrust of Elkins, affirms the authenticity of the Elkins tapes (Baker-Uris interview 1980). Only William Langley still maintains that the tapes were a clever fake (Langley-Uris interview 1980).

Whether the tapes were fake or genuine, the possibility still existed that Elkins may have initially planned to use them as blackmail, either to get money, as Langley suggested in 1980 (Langley-Uris interview 1980) and at the Senate Hearings (U.S. Senate Committee Hearings 1957), or to change the power relations between Langley and Elkins.

In the course of Elkins' accusations presented to the U.S. Senate Select Committee on Improper Activities in the Labor or Management Field (1957), he had indicated that the Commonwealth Corporation, a large real estate management and property holding firm in Oregon, had attempted to pick up some of the property held at the E-R site. This caused, on March 6, 1957, a response by Chester A. Morris, vice president of Commonwealth, and Carvel Iinden of the E-R Commission, that the Commonwealth Corporation had not been involved in attempting to make purchases at that site, but had merely sought one option to discover potential market value of property in the area as a service to the E-R Commission. It should be remembered that Commonwealth officers were among those, together with Norris, Beggs and Simpson, another large real estate firm, who had actively supported the Mayor Riley campaign against Dorothy McCullough Lee of the famous vice clean-up of 1948-1952 (MacColl 1978).

Elkins...just doesn't feel comfortable unless he's got you by the throat some way." (Langley-Uris interview 1980).

Doug Baker, in an interview conducted in 1980, suggested that Elkins used blackmail successfully in avoiding prosecution for a safe-cracking 
conspiracy after the vice probe itself (Baker-Uris interview 1980). Elkins, according to Baker's 1980 interview, knew of the presiding judge's homosexuality and was thus able to force a dismissal of the safecracking charges. That Elkins controlled and set up safe jobs was common knowledge both before and after the vice probe (Langley-Uris interview 1980; Baker-Uris interview 1980; Lambert-Uris interview 1979). Langley asserted that he had spread the word that the shakedown of thieves by the police, in tacit cooperation with Elkins, had to stop and that this prompted Elkins to move against Langley (Baker-Uris interview 1980; Langley-Uris interview 1979).

To what degree could Jim Elkins be considered a reliable witness? Certainly all parties involved today acknowledge that Elkins' motives were not unselfish. But there remains more than one plausible explanation for Elkins' decision to go public. For one-time Oregonian reporter William Lambert, the reason was that Elkins was fighting to survive:

You could hear Langley (on the tapes) talking...(his) very distinctive voice...telling Maloney about what they were going to do...to the "Character" they called Elkins, and how they were going to do it. They were going to cut him out... "This character is giving us a bad time." And God, he goes on and on. Elkins listened to all of this, and Elkins realized that he didn't have the clout, that he was in no position, really, to do anything about it. He was afraid of the Teamsters. He thought, well, if they got into a knock-down, drag-out, he didn't have any troops. These guys...could literally kill him, and then he was afraid of them, and I think when Wally (Turner) went out that day to talk to him that Elkins had probably just about come to the point where he figured maybe I'd better tell somebody on the newspaper about this. We learned later that he had said something to a Journal guy (Rolla Crick). (Lambert-Uris interview 1980).

Former District Attorney William Langley agreed that Elkins was frightened, but not of the Teamsters. Elkins, Langley said, was fearful 
of giving up power to Langley. Langley had written letters to Chief of Police Purcell insisting that the Chief close certain whorehouses that Langley knew to be run by Elkins' people. (This tactic was mentioned on the King Towers conspiracy tapes.) The Chief, Langley asserted, went to Elkins with Langley's letters. And Elkins showed up at Langley's house with the letters and a blackmail threat (Langley-Uris interview 1980). In addition, Langley, as mentioned elsewhere, had put out the word that the cozy arrangement between the police and Elkins' thief friends was to end (Langley-Uris interview 1980).

Langley asserted in the 1980 interview that Elkins often would inform on other criminals and thus keep himself in the good graces of the police (Langley-Uris interview 1980).

Elkins' role in fixing things was further delineated by Langley:

Whenever a thief or narcotics fellow would come into Portland, they would go see Jim Elkins, and he would see certain people at the police department; and these people could stay around without being harrassed. And if they happened to get caught, why, there was an opportunity that the charges could be reduced (Langley-Uris interview 1980).

Whatever Elkins' motives, the question of his reliability is paramount. William Lambert asserted flatly that Elkins was telling the truth (Lambert-Uris interview 1980) and that he was not a junkie despite arrests and convictions both before and after the vice probe for narcotics involvement (Lambert-Uris interview 1980; U.S. Senate Comnittee Hearings 1957). Yet Doug Baker and others insist that Elkins lied to the U.S. Senate Select Committee on Improper Activities in the Labor or Management Field (1957) when he said that he had never had anything to do with prostitution.

We used to talk to madams, and the standard thing was when you'd say, "did Elkins have anything to do with such and such a 
house?" their answer would be "Christ, he even counted the towels." (Baker-Uris interview 1980).

The Oregon Journal, no less than the Oregonian, had its own political axe to grind in the vice probe. It generally supported candidates opposed by its rival. It was in a circulation fight, a virtual struggle to the death. Yet its view of the vice probe was not, as the Oregonian and its supporters suggest, simply a reaction to being scooped. By November of 1956, the Journal had developed a detailed and plausible counter-theory of the vice situation written by Brad Williams.

The Unpublished "Other" Version. Williams indicated at that time that the Oregonian believed Terry Schrunk, William Langley and Clyde Crosby were representing a Seattle Teamsters mob. For his part, Williams saw Maloney and others not as Teamster goons but as Elkins' men. Williams argued that a circumstantial case existed to support the idea that Elkins' move toward publicity was not motivated out of fear of the Teamsters but out of a desire to hold on to an empire threatened by homegrown reform elements within the rising Democratic Party. What follows, then, is a summary of Williams' version of the Portland vice story discovered in its original manuscript form in the files of the Attorney General (Oregon State Archives):

Jim Elkins came to Portland and joined his brother in July of 1937 upon his release from prison in Arizona. He had been jailed for assault with a deadly weapon. There was at that time a loosely knit underworld in Portland which included men like Al Winter, Les Beckman, the Allen brothers and Fred Elkins, who ran brothels, slots and bootleg gambling joints. 
Stanley Earl was a bouncer for Fred Elkins. Earl was to rise in politics as the Elkins brothers rose in crime.

Fred and Jim Elkins, using force where necessary, expanded the Elkins empire. These operations included narcotics, for which Jim was sent to Leavenworth prison. By October of 1947, Stanley Earl, who had risen in the CIO, approached Mayor Earl Riley and insisted that unless Jim Purcell were made Chief of Police, evidence damaging to Riley would be released through a City Club Report. Earl was the principal investigator for the report. Riley refused.

By the time the report was published in February of 1948 , Riley had been repeatedly pressured. He had also been visited by Oregonian reporter Wallace Turner, who saw Riley as linked to Al Winter. Purcell and Earl worked together on the City Club Report. Riley was defeated by Dorothy Lee, who, unknown to her, received laundered funds from the Elkins group. Riley opened a Packard agency off Burnside Street.

In August of 1948, Stanley Earl, as a CIO executive, wrote to the Arizona authorities asking for a pardon for Jim Elkins, whom he indicated he had known for some time. Earl was joined in this by Governor John Hall and Portland Police Chief Leon Jenkins. The pardon was granted. Later Earl was to deny the importance of his action on Elkins' behalf. Earl on several occasions attempted to further the career of Jim Purcell.

In 1952, Earl was elected to the Portland City Council seat vacated by Fred Peterson, who successfully ran for Mayor. Elkins at this time reputedly controlled pinball in Portland.

Earl attempted to legalize pinball which had been ineffectively outlawed in the Lee administration. By January of 1954, the Teamsters in Seattle had decided to organize the pinball industry. Elkins attempted 
to join the Union with his men, but because the Union feared Elkins as a potential Jimmy Hoffa, who would both rival the Seattle group's power and bring unfavorable attention to the Union, the leadership refused Elkins and moved to shut him out of the pinball business. This was the origin of the picketing in Fortland of certain pinball locations. Elkins sold most of his holdings to Stan Terry and Lou Dunis.

In response to the shut out of Elkins, Stanley Earl reversed his position on pinball and denounced the devices. Crosby attempted to patch things up but found Earl enraged at Elkins' being shut out.

During the 1954 election, Elkins brought Maloney down to help Langley but also supported McCourt. Once elected, Langley, who had had bad dealings with Elkins, began to harrass Elkins by writing letters :0 state and city officials listing places operated by Elkins. (The tapes confirm Langley's action against the Elkins group using the "Spy," Leo Plotkin, but suggest that Langley was actively supporting the Seattle group in an effort to move into Portland and that the Seattle group initially suggested the letter-writing tactic.)

Maloney brought in McLaughlin to expand cardrooms, punchboards and other vice activities. A meeting was held in Maloney's apartment between Maloney, McLaughlin, Elkins and Norman Nemer, who at that time was a punchboard distributor. (Nemer would later marry Sylvia Schnitzer and leave gambling for the real estate business.)

Meanwhile, Plotkin continued to spy for Langley at Maloney's behest. One night Plotkin was beaten by two of Elkins' men, Joey Clemo and Chuck Brown. Plotkin confessed his spy role, and Elkins, now wise to the game, manipulated Maloney into an apartment at the King Towers. The apartment had been bugged in advance when two adjoining apartments were 
rented by Elkins two years previously. It was rumored that Elkins had a financial interest in the building and that the management was in collusion with Elkins.

Maloney had made no real progress in trying to set up Portland and gave thirty days' notice on his King Towers apartment on September 1, 1955. At the same time, his next-door neighbor, Bernard Kane, in whose apartments the recordings were being made, gave notice as well. Maloney was chased out of town by Elkins and by pressure from Seattle to abandon an impossibly complicated and compromised plan.

Langley continued to push Elkins, who responded by trying to blackmail Langley and Crosby intr. silence and cooperation using the King Towers conspiracy tapes.

When the very popular Terry Schrunk, who it had been assumed would run for Secretary of State, decided instead to run for Mayor, Elkins realized that his power was broken and with nothing to lose decided to make his tapes public. Elkins had corruption rumors spread throughout the city (Brad Williams, Manuscripts, Oregon State Archives).

This version of the events surrounding the vice probe emphasizes the tie-ins between Earl, Purcell and Elkins. It does not, however, explain away the ties between Seattle Teamsters leadership and Maloney and Mclaughlin. Nor does it explain Langley's apparent involvement with the Seattle group which is clearly revealed on the King Towers conspiracy tapes. On tape, Langley is clearly identified as saying that he is owed $\$ 8,000$ by Elkins and his people (Oregon State Archives, 69A 52/2, Tape R9-1).

Williams' version has another major weakness. He asserts that Langley's letter-writing campaign revealing Elkins' joints began before 
Maloney was persuaded to move into the King Towers. Yet the tapes show Maloney and McLaughlin inventing the tactic while in the King Towers. More importantly, it was the Seattle men, not Langley, who first suggested the idea of the letters.

In the end, despite the volumes of documents, tapes, accusations and counter-accusations engendered by the Portland vice probe, only these things had changed: The obvious aspects of the vice scene disappeared; the public career of William Langley was ended; James Elkins faced a possible jail sentence which was later reversed by the Supreme Court; and most importantly, the Teamsters-connected Seattle group had disappeared.

The Schrunk Position and the Portland Network

Mayor Terry Schrunk's role in the Portland vice situation remains unclear. Unfortunately, Schrunk is dead. His perspective would be lost to us were it not for the survival of those who were close to him. Schrunk's friend and long-time supporter, attorney Raymond Kell, is still active in Portland, practicing law. It is from Kell that a view more closely akin to that of Terry Schrunk's can be gained.

Raymond Kell came to Portland during the late war years when the city had a reputation of being wide open. His law practice in Portland began under Gus Solomon, who was his senior partner until 1949 when Solomon became a United States District Judge. Kell, along with Solomon, was instrumental in choosing Terry Schrunk, then a career fire fighter, as the Democratic Party's choice for Multnomah County Sheriff after the ouster of Democrat Mike Elliott. (Marion L. (Mike) Elliott held brief tenure as Sheriff after defeating Republican machine candidate Martin Pratt in November, 1948. Taking office in January of 1949, he was recalled 6 months later.) 
During the years of the Schrunk administration, Kell served on various civic commissions, the Portland Dock Commission and later the Port of Portland Commission. Kell's career rise closely paralleled that of Terry Schrunk. Kell was Schrunk's campaign manager in his race for Sheriff and his successful challenge to the Republican-dominated Peterson incumbancy in 1956. Kell acknowledged the close ties of friendship and legal advice that existed between his law partner Gus Solomon and gambler, entrepreneur Al Winter. Winter was described by Kell as being active in liberal causes along with Kell and Solomon. Kell and the others shared with Schrunk a strong commitment in the $1950^{\prime}$ 's to an organization in those days characterized as being dangerously sympathetic to left-wing causes - The Americans for Democratic Action (ADA). The ADA was formed in reaction, Kell said, to the cold war attitudes and actions of President Harry Truman (Kell-Uris interview 1981).

Kell saw the Portland vice probe as growing out of a number of diverse elements all of which came together as he put it, "like pieces of a mosaic."

Kell indicated the following factors as crucial to the probe:

1. Oregonian reporters Lambert's and Turner's successful investigations of Indian land frauds led the two reporters to seek yet another sensational expose;

2. Elkins' decision to go public with his blackmail tapes;

3. The appearance in Portland of Tom Maloney and Joe McLaughlin who had ambitions to become involved in Portland vice activities; 
4. The continuing successful challenge to Republican hegemony in Oregon state politics and more particularly in Portland's regional politics by the Democrats;

5. The Oregonian's continued commitment to the Elkins story despite mounting evidence to discredit him and his cohorts;

6. Robert Kennedy's decision to begin the Hearings of the U.S. Senate Select Committee on Improper Activities in the Labor or Management Field (1957) with a sensational expose of an attempted Teamsters take-over of vice and political power in Portland.

Kell described Elkins as a "self-starter" very much on the fringe of the Portland scene. Elkins' tape recordings were made as a part of an attempt at genteel blackmail, Kell suggested. This is confirmed by Langley (1980) and Thornton (1980). Elkins had established himself in Portland and was allowed to operate through the tolerance and occasional active help of the Portland Police Department. In exchange, Elkins informed on burglars, safecrackers and other outsiders for the police department. This cozy arrangement was disrupted first by William Langley's election as District Attorney and then by Schrunk's refusal to cooperate in a policy of tolerance in areas under his jurisdiction (KellUris interview 1981). This view is shared by William Langley (LangleyUris interview 1980).

Ray Kell insisted that the only thing Terry Schrunk was guilty of was naivete. The raid on the $8212 \mathrm{Club}$ in Kenton was made out of frustration and on the spur of the moment in the early morning hours after Schrunk had had a few drinks and was on his way home. This was why the Sheriff's deputies involved were in uniform and why Schrunk was there. 
Kell reiterated the oft-made point that if Schrunk were taking bribes, he would hardly do so in such a public manner.

Kell said he urged Schrunk at the time of the Senate Hearings to bring a lawyer with him. But Schrunk, at that time a loquacious and open person, felt that he could handle Robert Kennedy's questions. He balked at the lie detector test when he realized that the questions that he was asked had more than one meaning and that the truth or falsehood of his answers was not as simple a matter as he had assumed it would be (KellUris interview 1981).

Schrunk's indictment for perjury on the bribery question came, Kell said, only after the Grand Jury had several times had the matter presented to it and refused to issue a true bill. Attorney General Thornton introduced the matter to the Jury after being pressured repeatedly by the Oregonian. Thornton acknowledged the repeated pressure and repeated referral to the Grand Jury in a 1980 interview (Thornton-Uris interview 1980).

For Mayor Terry Schrunk, who was found not guilty of perjury, Kell said, the negative publicity, humiliation and expense of the trial meant a real change in his attitudes and politics. Schrunk, an open easy-going liberal, became a cautious, far more conservative and somewhat disenchanted man.

"That 18 months changed his personality and career ambitions. Terry Schrunk became much more suspicious, cautious and conservative" (KellUris interview 1981).

Kell described the period of the vice probe as the end of an era. The city under Mayors Carson, Riley and Peterson had been robust and open. It was a period in which policemen at all levels were commonly 
bribed. Bribery, both subtle and direct, was an acknowledged way of financing politics during those years (Kell-Uris interview 1981).

On the question as to whether or not there was a syndicate in Portland, Rell said that,

"there had been a pattern of that in that whole decade. It was a genteel, home-grown sort of thing. I never had any sense of outsiders, no Mafia Involvement." (Kell-Uris interview 1981)

Kell confirmed that there was a racetrack wire at Winter's Pago Pago Club. There was gambling frequently at the Multnomah Athletic Club, the Arlington Club and the University Club, all upper-class clubs. It was here that the elite of the gambling world socialized with Portland's upper crust. Gambling was equally genteel at Duncan's. Games like Pan were played, largely by successful older Jewish men (Kell-Uris interview 1981).

Al Winter was seen by Kell as being at the top social and economic strata of gambling in Portland. At the next level were men like Norman Nemer, Lou Dunis and Stan Terry. "If pinball was illegal then they were illegal" (Kell-Uris interview 1981).

Far below these men, Kell suggested, were fringe operators with great ambitions and few connections, like Jim Elkins.

Kell emphasized that men like Stan Terry had nothing to do with the crowd with which Al Winter was associated. The three strata had little to do with each other and men like Elkins were not welcome in the company of those at the top (Kell-Uris interview 1981).

It was, Kell said, an era of accommodation, "...there was some of the paternalism of the big-city machine - a Republican machine. If people were down on their luck, they would tide them over." (KeIl-Uris interview 1981). 
Kell saw District Attorney William Langley as a victim of Elkins. "Langley would never have been convicted of malfeasance had he properly prepared his case when he was set up by Elkins at the Jack \& Jill Club," Kell said (Kell-Uris interview 1981).

The various elements of the mosaic lay about waiting for the magnet that would bring them together. They were drawn together by the Oregonian's interest in maintaining Republican power and its own credibility. Elkins' credibility came through the police department. He was, Kell suggested, a very convincing talker.

Kell felt that the Teamsters were making no special inroads in Portland; that official Teamster action in Portland was no different than in other cities throughout the nation. Clyde Crosby, Teamsters head for Portland, was only a name and not a "wheeler-dealer" (Kell-Uris interview 1981).

Tom Maloney's connection to the Teamsters Union and to Ciyde Crosby was largely discounted by Kell. Maloney, Kell believed, was like Elkins, an ambitious self-starter who manipulated others to his own ends (KellUris interview 1981).

Democratic Party head Howard Morgan's belief that the Teamsters were moving in was explained by Kell in terms of Morgan's propensity to see things in large terms, "He was a giant slayer" (Kell-Uris interview 1981).

Kell felt that much of Morgan's animosity toward Schrunk had developed in 1952 when Schrunk had supported Estes Kefauver, bolting from the liberal position of Howard Morgan and others who supported Adlai Stevenson. 
"There was no central theme to this thing," argued Kell, "the key was Elkins and the discredibility of Elkins. I think it was one of these things where all these pieces were laying around and a magnet was introduced. The Oregonian's hard line was the magnet. The significance of the various aspects and relationships was an artificial creation. If a paper ever lost responsibility and became an advocate, it was the Oregonian. They just wanted to send people to jail. The Journal was more responsible. of course, it served its purposes - as witnessed in the election returns." (Schrunk received the plurality of votes in the May primary and survived the allegations to be elected Mayor over Republican Fred Peterson.) "Peterson's loss in the primary must have hurt the Oregonian, which is why they pushed so hard to have Terry indicted before the fall election." (Kell-Uris interview 1981)

In an informal unpublished brief on Elkins and the vice probe developed after the Schrunk trial, Kell carefully documented 18 instances in which Elkins was contradicted by various witnesses during the Langley, Schrunk and Crosby trials before the U.S. Senate Select Committee on Improper Activities in the Labor or Management Field (1957). The contradictory witnesses, in many instances, may have been no more credible than Elkins, yet the sheer volume of contradiction must suggest that Elkins' veracity was questionable. The areas in which Elkins' testimony was contradicted include the following list from that unpublished brief:

1. His drug addiction;

2. Statements made by him to Probation officer McFarland in May, 1957 regarding use of drugs;

3. The James Burr Miller incident;

4. Alice Erickson's affidavit re: Attorney General's promise of immunity for Elkins;

5. Elkins' efforts to obtain police Officer Elmer Loos as witness for E-R story;

6. Schrunk's advice to re-open the $8212 \mathrm{Club}$;

7. Elkins' 1955 visit to Schrunk's office;

8. Stan Terry - $\$ 10,000$ initiation fee to Teamsters;

9. Completeness and accuracy of Elkins' records for the 8212 Club and other clubs;

10. Elkins' knowledge of bookkeeping - contradictory statements by Elkins; 
11. Elkins' acquaintance and meetings with Janice Langley;

12. Elkins' offer to sell tapes to Langley for $\$ 10,000$;

13. Elkins' offer to sell tapes to Crosby;

14. Elkins' possession of original letters from Langley to Purcell;

15. Campaign contributions by him to Langley;

16. Elkins advises Johnson of Crosby interest in E-R options;

17. Elkins-Crosby meeting at $21 \mathrm{~s} \dot{c}$ and Division Streets;

18. Elkins-Crosby discussions re: E-R options (Kell n.d., n. pag.).

In summary, Ray Rell saw the vice probe as largely a coincidental phenomenon in which a number of ambitions and interests happened to coincide. From his perspective, the result was an increased attitude of conservatism on the part of the rising new elites within the context of the Democratic Party's challenge to Republican hegemony. 


\section{CHAPTER V}

ANALYSIS OF THE PORTLAND VICE PROBE

This chapter analyzes and evaluates the material previously developed in the case study of the Portland vice probe. This chapter is divided into two parts: 1 . Discoveries and evaluations made during the study about the vice probe under investigation; 2 . An analysis of the probe in terms of the set of propositions developed during the review of historical, sociological and political science literature.

\section{What Really Happened?}

The three major sources of data for this study; mass media, government documents and interviews, do not all agree one with the other or within each source area. This is a common and expected problem in historical case study research. There are, however, a number of points upon which there is adequate evidence to develop some conclusions about what occurred during the period under investigation.

How did the vice probe begin? The probe began with an effort by James B. Elkins, a local racketeer, to protect and possibly improve his economic situation in the face of changes that were occurring in the local political and organized crime scenes. Repeatedly sources indicated that Elkins faced a possible end to his arrangement of tolerance with the Portland police in exchange for providing information to them on other criminal activities. 
Elkins, who denied that he had used blackmail, first went to a number of officials, including the local head of the Teamsters Union, Clyde Crosby, and the Multnomah County District Attorney, William Langley, to pressure them into a more tolerant position vis-a-vis his operation. He did this because he claimed the Teamsters, in the persons of Tom Maloney and Joe McLaughlin, were attempting to move in and cut him out of his business. William Langley, however, suggested that Elkins was acting because Langley had indicated that the old arrangement of toleration would no longer apply now that he was District Attorney (LangleyUris interview 1980). There is ample evidence to suggest that both Elkins and Langley are being truthful in this instance, but have a different perspective on events.

Having failed in his attempt to oust the men he believed to be supported by the Teamsters, and knowing that he could not use force against so powerful an adversary, Elkins went first to the Oregon Journal and second to the Oregonian with the clandestine tape recordings he had made of conversations among Maloney, McLaughlin, Langley and others at the King Towers Apartments. The Journal was unresponsive. The Oregonian, having experienced success in other recent exposes, believed Elkins and ran uncritically his version of the Portland vice story. These stories were written by Wallace Turner and William Lambert. Parts of Elkins' version was independently supported by Howard Morgan, State Chairman of the Democratic Party.

What changes were under way that affected events? The Democratic Party, after years of failure at the polls, was on the rise in Oregon and, more importantly, in the Portland metropolitan area. The Oregonian, a Republican paper, had an interest in stopping or reversing this trend. 
Elkins' arrangements with the police and others may have depended upon the maintenance of the predominantly Republican city administration led at the elective level by Fred Peterson in a nominally non-partisan mayorcouncil system. There is no evidence to indicate that Peterson himself gained financially by the policy of vice tolerance then customary in Portland. Peterson has denied that any policy of tolerance existed (Peterson-Uris interview 1980).

The decision of then Sheriff Terry Schrunk to run for mayor was another possible factor in Elkins' decision to go public with his tape recordings. The tapes indicate that Schrunk, a Democrat, did not share the attitudes of the Portland police toward vice and its operations.

Did the Teamsters move in? During this period the Teamsters Union was organizing the pinball and vending machine industry in Portland. The Union may have had ambitions beyond the organizing effort, however. There are indications that the Union was interested in supporting candidates for office in return for influence in matters of public policy. Two such areas were the liquor industry and the selection of a District Attorney for Multnomah County. The Union also gave apparent support to Terry Schrunk's bid for mayor, although this is consistent with labor's general stand against Republican candidates and Schrunk's then liberal pro-labor reputation.

The U.S. Senate Select Committee on Improper Activities in the Labor or Management Field (1957), Howard Morgan and the Oregonian all insisted at the time that the Teamsters were making a concerted bid for power in Oregon. There was much evidence presented at the Senate Committee Hearings and in the Oregonian to support this view. 
Others, including Ray Kell, argue that the Teamsters had no special interest in Portland, and that there was little to be gained in so small and poor a state by the Union. (Kell-Uris interview 1981; anon.-Uris interview 1980.) These observers see the Union's actions as typical of union policy at the time but of far less ambitious intentions than did the Oregonian and the Senate Committee. The attack on organized labor launched in Portland by the U.S. Senate Subcommittee on Improper Activities in the Labor or Management Field (1957), and led by council Robert Kennedy, resulted in the passage of the Labor-Management Reporting and Disclosure Act of 1959, known as the Landrum-Griffin Law.

It is difficult to make a definitive statement on the role of the Teamsters in Portland at the time of the vice probe. The men who claimed to represent the Union in their bid to restructure the organized vice scene in Portland, Tom Maloney and Joe McLaughlin, were tied through various documents and testimony to the Teamsters' leadership in Seattle. Howard Morgan reported that he was told by Maloney to allow the Teamsters to influence OLCC decisions and appointments and that local Teamsters head, Clyde Crosby, backed Maloney on this matter. Maloney did attempt to gain influence and power using the Teamsters name. He did play a major part in getting William Langley elected Multnomah County District Attorney.

Yet Maloney was, as Ray Kell described him (Kell-Uris interview 1981), a real self-promoter. It is difficult to separate Maloney's claim from the truth. It is even less easy to be clear on what Clyde Crosby's role was. He may have been Maloney's dupe or a conscious agent of the Teamsters Union acting in concert with Maloney (U.S. Senate Hearings 1957). 
What role did the Oregon Journal play? The Journal, having missed the opportunity to use the Elkins story, quickly developed a position in contradiction to that of the Oregonian. It was highly critical of the Elkins story. It participated through its reporters Doug Baker and Brad Williams in an illegal raid on the home of Ray Clark, an Elkins employee. There the tapes that resulted in Elkins' conviction on federal wiretap charges (later reversed) were discovered along with a Miniphone recording machine belonging to the Portland police.

The Journal, which supported Terry Schrunk and attacked incumbent Mayor Fred Peterson, was a nominally independent evening paper, with a definite Democratic bias. It was involved in a fierce rivalry and circulation struggle with the larger, morning Oregonian.

Both papers have been critized for ruthless advocacy journalism in the vice probe. Yet the competition served to bring more information to the public thaa if they had not been independent rivals.

How extensive was the corruption? Evaluating the level of corruption involved is difficult. It is made all the more so because, as is so often the case, there was no consensus cn what really happened. There is general agreement, however, that in those days bribery and arrangments of mutual benefit among organized vice figures, politicians and police were commonplace in Portland (Kell-Uris interview 1981).

Yet, no policemen were convicted of bribery or other forms of corruption during the probe. District Attorney William Langley's conviction for malfeasance was eventually overturned and Terry Schrunk was found not guilty of perjury in connection with his denial to the grand jury of having taken a bribe from Clifford 0. (Jimmy) Bennett, operator of the $8212 \mathrm{Club}$. 
Three Types of Police Corruption. Lawrence Sherman (1974) identified three types of corrupt police organizations. Type $I$ is the form most often acknowledged to exist by the police themselves. Sherman called this type "Rotten Apples and Rotten Pockets" (1974, p. 7). In this form corruption is minimal and is a reflection of the behavior of a few independently operating corrupt policemen.

Type II involves a majority rather than a minority of a given department in corrupt practices. Corruption is here endemic and involves tolerated, independent graft-taking and bribery at all levels of the police hierarchy. Sherman called this type "Pervasive Unorganized Corruption" (1974, p. 9).

Finally, Type III involves pervasive corruption as in Type II, but is organized and structured. It extends beyond the police department to other elements of the criminal justice system, including district attorneys and judges. It also involves elected high officials and high bureaucrats. Chambliss (19\%8) and Steffens (1904) argued that this type is common. Under this system policemen are directed to make pickups of smile money. Sherman called this type "Pervasive Organized Corruption" (1974, p. 10).

During the course of this study, all three data sources seem to show that Portland, at the time of the vice probe, was a Type III city. Yet there is no agreement among those sources about exactly which people were involved or how the organized corruption took place.

Did the expose and subsequent events end the corruption? Interviews taken with Captain Reiter (Reiter-Uris interview 1980) of the Portland police and anonymous respondents (anon.-Uris interview 1980) indicate that while the kind of police corruption existent in the mid- 
$1950^{\prime}$ 's has ended, there is still today corruption of the Type III form. Reiter argued that present-day corruption is now limited to the Type I form among police but Type III among politicians (Reiter-Uris interview 1980)

Respondents like Ray Kell (Rell-Uris interview 1981) and others argue that what corruption now exists is of the Type I form. Recent revelations in Portland suggest that at the least, Type I form corruption continues.

Was there an organized crime syndicate in Portland? Various sources acknowledge the existence of a cooperative, local, criminal cabal at work in Portland. It has been characterized as relatively genteel and hierarchical (Kell-Uris interview 1981). It had developed and had access to informal networks of association and business dealings with other elites in the economic, criminal justice, legal and political communities. Some argue that it was relatively benign and/or no longer exists (Kell-Uris interview 1981). Other sources insist that it continues to flourish on various levels (anon.-Uris interview 1980; Reiter-Uris interview 1980). One source sited the recent restoration of pinball by the city council as an example of its influence (Reiter-Uris interview 1980).

Pinball was relegalized on November 10, 1977. This action by the city council rescinded a referendum passed on May 18, 1956, the same day Terry Schrunk received a plurality of votes for Mayor. In 1977, the pinball industry was represented by Ted Runstein of the firm Kell, Alterman and Runstein. 
The Propositions and the Case History

Earlier in this work a set of propositions was developed from the observation of sociologists, political scientists and historians concerning the nature of corruption and vice and responses to those phenomena. The propositions serve to suggest some of the elements that may be useful in developing a general understanding of both the phenomena of vice and corruption and the reactions to those events. Emphasis was placed upon situations in which there was reaction to corruption and vice networks.

The works of functionalists and Marxist sociologists were used to suggest a general commonality of understanding based on the notion that these official irregular practices and activities are useful to the maintenance of the social system.

The first proposition developed was that:

I. URBAN VICE AND CORRUPTION SERVE TO MAINTAIN SYSTEMIC NEEDS.

Looking at Portland, Oregon during the period under study, a pattern emerges. Tom Johnson, who provided liquor to a mixed clientele in the $1920^{\prime} \mathrm{s}$ and bankrolled black vice operations throughout the 1940's and $1950^{\prime}$ s, was useful to the community not only as a bootlegger and a provider of illegal services. He also served as an agent of social control in the black community and communicated the demands of whites and the needs of blacks to an established informal community network which included black ministers, black doctors and others. Through him the police could keep track of activity within the black community.

In a relationship (probably unspoken, but certainly understood) of mutual benefit, his operation was generally tolerated in exchange for his cooperation in the policing of black Portland (anon.-Uris interview 1980). 
James Elkins operated in much the same way in the white vice world. William Langley (Idngley-Uris interview, 1980) emphasized the arrangement for informal crime control that Elkins had established with the Portland Police Department. Crime was thus franchised, limited and ordered. For the police this meant less trouble, less risk and less public complaint. Vice could exist while the public stand of politicians and the law remained officially supportive of a crime-free city. Vice in general met needs in Portland. And vice tolerat on was useful as a device for social control.

II. ORGANIZED CRIME IS TOLERATED AS A USEFUL DEVICE FOR PACIFICATION OF POTENTIALIY REBELLIOUS POPULATIONS.

Energies that might otherwise be turned to political action are spent in the effort to acquire wealth through acts outside the law and in the pursuit of pleasures officially circumscribed. In the process, the legitimacy of claims on society by the oppressed is compromised and tainted.

In Portiand, large numbers of working men were consumers of vice services (Lambert-Uris interview 1979). Others turned their attention to making money by providing these services.

In a more speculative vein it can be argued that if men like Tom Johnson had not had access to an alternative route to wealth they might have developed a more radical political perspective. This might have led to demands for fundamental social change (Spitzer 1975).

All of this suggests that Proposition II is consistent with the findings in the Portland study.

Kell, Langley, Lambert and Baker (Uris interviews 1981, 1980, 1978 and 1980, respectively) all agreed that the existing arrangements in 
Portland between the police and men like Elkins continued for many years unchanged in most aspects. When change did occur in 1956, it came about because of public attention and outside forces. These issues will be dealt with later.

III. WHEN CRIMINAL CONSPIRACIES ARE PERCEIVED AS A THREAT TO THE STATE'S IEGITIMACY, THEY THEN BECOME THE OBJECT OF OFFICIAL ACTION.

These pressures for change left the powerful in Portland with a limited choice. To ignore the negative attention and corrupt activities could result in a public demand for even more sweeping alteration of existing power relations. The response of the state was quite predictable. It undertook a Iimited investigation through the appropriate channels, in this case the grand jury system. Those who suffered were those who had been most clamorous in denouncing the existing system and who themselves were a part of that system. In the process, public faith was restored in the capability and legitimacy of the system to identify and correct the perceived problem.

IV. REFORM FREQUENTLY ACCOMPANIES THE RISE OF THE NEW ELITES IN THE CITY. IT IS PART OF A LARGER STRUGGLE FOR CONTROL INVOLVING MAJOR POWER SHIFTS.

In Portland, two reform movements were outlined. The first, in 1948, saw the rise of an outgroup led at the public level by Dorothy McCullough Lee, whose successful mayoral campaign was widely believed to occasion a vice cleanup which accompanied changes in the police department. There is disagreement among sources as to how thorough this cleanup was. Certainly the visible sin dens were closed for a time. Yet, as was shown earlier, a multitude of sources suggest that the Lee shakeup was temporary and did not strike to the heart of the syndicate. 
The second movement, during the vice probe of 1956, closely paralleled the rise of the Democratic Party in its successful challenge of the Republicans for dominance of Portland politics. At the same time, the leading public initiator of the vice probe, the Oregonian, was a Republican paper. It cannot be said then that the probe, whatever the motives for its initiation, was a totally controlled or manipulated event.

While party politics was an important factor in the choosing of sides during the probe, the new elite, whose political ascendance occurred during the probe, more closely reflected the entrepreneurial orientations suggested by Hays (1964) and Lubove (1969). By 1960 these rising elites had gained significant economic and political power in Portland. Under Mayor Schrunk the old south-Portland area came under the control of a new development agency, the Portland Development Commission, created in 1958. A new industrial base was also becoming part of the Portland economic establishment (Kell-Uris interview 1981).

Yet the man who officially led these new forces at the political level, Terry Schrunk, was himself tainted with accusations of corruption. His humiliation at the hands of the U.S. Senate Select Committee on Improper Activities in the Labor or Management Field (1957) has been detailed in Chapter IV. His eventual trial and acquittal of bribery charges notwithstanding, there was little that his supporters could do to purify his somewhat soiled image as a reformer. Interestingly enough, Schrunk's career was characterized as free of scandal and even puritan (Kel1-Uris interview 1981).

New elites, then associated with the Democratic Party, were rising at the time that the vice probe occurred, yet there is no definite 
evidence suggesting a causal relation between the probe and the rise of new power groups. Rather, as is often the case in politics, the new groups were able to use some implications and revelations uncovered in the struggle, but sometimes were harmed by other events which were part of the probe.

V. URBAN STRUCTURAL REFORMS IN SUCH AREAS AS LAND USE PLANNING SERVE THE ECONOMIC INTERESTS OF POWERFU ELEMENTS IN THE CITY AND AT THE SAME TIME PROVIDE NEW OPPORTUNITIES FOR CORRUPTION.

The creation of the Exposition-Recreation Commission meant economic growth for the business community in general and for land holders at whatever site was finally selected. It also meant an opportunity for corruption within the commission and a concurrent opportunity for speculation based on that corruption by elements of the underworld. Here too, however, the state failed to prove a conspiracy to benefit through special knowledge of the E-R site location.

Yet the accusation of such a conspiracy is repeated by countless sources in the course of the probe. Members of the alleged conspiracy did make land purchases at the site selected by the E-R Commission (the Memorial Coliseum).

VI. OPPORTUNITIES FOR VICE AND CORRUPTION CAN EXIST DUE TO THE CONTRADICTION BETWEEN IDEALIZED NORMS AND ACTUAL BEHAVIOR AS REFLECTED IN CRIMINAL IAW.

Making desired acts illegal does indeed create crime. Daniel Bell (1960) emphasized the conflic stween Puritan morality made into law and the actual desires and behaviors of the people as a major factor in creating illegal activities which present opportunities (as Sherman (1974) and Gardiner (1970) suggested) for police corruption. This was expressed as the above proposition. 
It can be seen that the issue of the outlawing of pinball did create an opportunity for the Teamsters to organize that trade. The Teamsters targeted the pinball industry for an organizing effort at the same time that the industry was outlawed by the City Council. The industry came together in the Coin Machine Men of Oregon in the face of the effort to ban their business. It seems probable that had the industry not been placed in jeopardy, there would have been little opportunity for the Teamsters to use the pinball dealers association in the organizing effort.

The state monopoly on the liquor industry offered the outsiders another opportunity to gain power and influence. Liquor control under the Oregon Liquor Control Commission had long been thought of as a major area for influence peddling and bribery (Thornton-Uris interview 1980 . It is campaign contributions in exchange for favors relating to the OLCC that must share significance in the process of corruption and influence allegedly demonstrated by the Teamsters Union in Portland.

VII. ORGANIZED CRIME IS NOT AN EXCLUSIVE PROVINCE OF ANY PARTICULAR ETHNIC GROUP.

In Portland the organized crime cabal that existed clearly involved territories with ethnic divisions. Yet there was interaction, cooperation and exchange among these groups. The pattern of ethnic division appears more as a matter of convenience than of exclusive ethnic tradition. The classic Italian-American cxime family model, as suggested by organized crime theorists who believe in a national crime organization with an ethnic base, did not reveal itself to have existed to any extent in Portland in the 1950's. Indeed, the only interstate organized crime syndicate suggested to exist by the material available on 
the Portland vice probe of 1956 was an allegedly corrupt labor union with a complex national organization, the Teamsters. But the importance of this to the total of Portland's corruption problems is questioned by several sources (Kell-Uris interview 1981; anon.-Uris interview 1980). These sources argued that the Teamsters' activities in Portland were no different than those carried out elsewhere. The acts of persons such as Tom Maloney and Joe McLaughlin may not have represented the Union's wishes as they claimed. Instead they were mistaken for the acts and policies of the Union itself.

VIII.AUTHORITATIVE, EXTERNALLY ORIGINATED AND VERIFIED CONDEMNATION OF IOCAL CORRUPTION IS A MAJOR FACTOR FOR LOCAL REFORM.

Earlier it was suggested by Gardiner (1970) that federal intervention and condemnation was a factor stimulating local reform.

In Portland, the probe began when two elements within the community from very diverse backgrounds presented essentially the same story to the Republican oriented newspaper, the Oregonian. Interestingly enough, one of these, James Elkins, said he went first to the Oregon Journal, the Oregonian's rival. Howard Morgan, the other figure, came to the Oregonian with much the same tale as Elkins had told: his version agreed with Elkins that the Teamsters were moving in on vice in Portland. The stories' credibility was improved by corroboration from different levels of society. But it was the outside investigation of the Teamsters move on Portland that probably had the greatest impact on the city's selfimage. The U.S. Senate Select Committee on Improper Activities in the Labor or Management Field (1957) essentially repeated the Oregonian version of the Portland story and in the process made it a national scandal. Yet, in Portland there is remarkable consensus even today that 
the Senate Committee was unjust and that the treatment afforded witnesses was unfair.

This suggests that while externally verified condemnation did have impact upon the vice probe it did not particularly further, in the public mind at least, the credibility of the accusations made.

In fact, for some, the effect was rather the opposite. Many argue that the Senate Committee was decisive in turning people away from concern about the internal problems of Portland and toward concern for creating a positive, wholesome image for the city.

Many vice operators were closed down as a result of the probe. Yet there is no consensus that vice activity per se was necessarily reduced. Corrupt practices to the degree that they existed within the police department may or may not have been altered. All that can be said with certainty is that most officers at all levels survived the probe. There are at least two possibilities that can explain this: 1. That everyone was innocent or, 2. Everyone stopped doing the bad deeds they were accused of when the exposure took place.

One standard reform commonly suggested for problems of police corruption is to increase the pay, status rewards, advancement opportunities and supervision of police departments. This is Gardiner's (1970) suggestion and it was the conclusion of the Portland City Club Report in 1948. This is the inspiration for proposition IX:

IX. WHERE STRONG REWARDS, ADVANCEMENT OPPORTUNITY, HIGH STATUS AND CLOSE SUPERVISION OF POLICE DO NOT EXIST, PAYOFFS WILC TEND TO BECOME POLICY.

Obviously there are limits placed sooner or later upon advancement opportunity. For example, not every officer can become a police captain 
or lieutenant. There will be some who will not advance at all or will experience very limited advancement. One way to avoid this is to increase the number of high-paid, high-status, command-level positions. This produces one of two results: top-heavy organization which is expensive to operate, or an increase in the size of the police department itself to justify the new rank of sergeants, lieutenants, captains and commanders.

Similar problems exist with higher pay. There are limited monies in the city budget. All agencies must compete for that money (Weinstein 1968).

That payoffs existed in Portland was agreed upon by many sources (Kell-Uris interview 1981; Lambert-Uris interview 1979; Langley-Uris interview 1979). In Portland, as in most locations, the police tend to close ranks around their own (Sherman 1974).

X. VICE AND CORRUPTION ARE STRUCTURED THROUGH THE POLITICAL SYSTEM AND LAW ENFORCEMENT INTO THE OPERATION OF VARIOUS BUSINESSES.

In Portland the outlawing of pinball was a pivotal issue around which a great deal of political pressure and organizing efforts developed. The coin-machine men of Oregon came together through an organization to lobby in the interest of their business. Once organized, this group was brought into the Teamsters Union, again to increase its political clout through an alliance with a powerful outside network.

As Kell suggested (Kell-Uris interview 1981), the pinball operators were legitimate businessmen until their trade became illegal. Had this not happened, there may well have been less pressure to attempt to influence other aspects of the political system. 
XI. ORGANIZED CRIME, WITH ITS USES OF VICE AND CORRUPTION, IS NO DIFFERENT THAN OTHER FORMS OF BUSINESS EXCEPT THAT, BECAUSE THEY CANNOT RELY UPON THE LEGAL SYSTEM TO ENFORCE THEIR BUSINESS ARRANGEMENTS, ORGANIZED CRIMINALS CAN AND DO RESORT TO THE USE OF VIOLENCE AND OTHER EXTRA-LEGAL SANCTIONS.

Two basic theories are presented in this history as to why James Elkins went to the newspapers with his tale of Teamsters takeovers. The Oregonian's version, which was shared by the U.S. Senate Select Committee on Improper Activities in the Labor and Management Field (1957) held that Elkins was afraid of the Teamsters and in the process of eavesdropping and wiretapping discovered that he was being cut out of the action. This explanation was never made part of the Oregonian's public analysis of the probe.

The Oregon Journal argued that Elkins, facing a change in administrations, feared exposure and had to attempt blackmail to keep his power. When that failed, he carried out his threat and went to the press. Articles in the Journal questioned the veracity of Elkins' tape recordings.

It may well be that both versions are true. The unpublished analysis of the probe credited to the Oregon Journal from the Oregon State Archives and the Journal suggest that Elkins was caught in a political power change that would oust those who tolerated him; Republican Mayor Fred Peterson and his Chief of Police, James Purcell. This was confirmed by Ray Kell and William Langley (Rell-Uris interview 1981; Langley-Uris interview 1980).

Elkins' motives remain unclear, but that he was a businessman who could not legally enforce agreements is clear. 
From the evidence, Tom Johnson, Swede Ferguson, James Elkins, a11 conducted their business in much the same way as other businesses. Loans were made for percentages of profits (known generally as "buying a piece of the action"). This is not much different than arrangements made in the legitimate business community.

Elkins could not resort to violence against the Teamsters Union for that was a struggle he could not win. It is likely that he was aware of this. He had little choice; his power was threatened no matter what he did. It was pointless for him to go to court. None of his contracts were enforceable through the legal system. Instead, whether or not he tried to blackmail his attackers first, he went to the press and to the court of public opinion.

XII. A VICE PROBE WILL AFFECT THOSE INVOLVED IN INVERSE PROPORTION TO THEIR POWER, PRESTIGE AND WEALTH.

Chambliss (1978) suggested that the higher socio-econimic status or more politically powerful an individual was, the less likely their public and private lives would be affected by a vice probe. In Portland, the highest official affected in terms of career and conviction was Multnomah County District Attorney William Langley.

He was ousted from office after a conviction for failure to prosecute the operators of a slot machine. His conviction was later overturned and he served no time in prison. He eventually was readmitted to the Oregon bar. Whether Langley was simply sacrificed to protect someone else is unclear. What is clear, however, is that such insiders in the Democratic Party as Howard Morgan, had no faith, trust or belief in the loyalty of William Langley. This was because of Langley's association with the Teamsters Union and his alleged associations in the 
past with James Elkins and others. However, Langley's father was an established and respected lawyer in Portland. It is not clear that Langley was anything more or less than a man following a traditional political career path. His interview (Langley-Uris interview 1980) indicates that it was his challenge to the established procedure of cooperation between the police and the criminal element under Elkins' leadership that led to Elkins' blackmail attempt. As suggested earlier, Elkins' operations were tolerated by the police for reasons of mutual advantage. These included Elkins' role as an informer on thieves and Elkins' use of bribery (Kell-Uris interview 1981).

Langley was the only important figure to suffer at the hands of the courts. But the Chief of Police, James Purcell, former Mayor Fred Peterson, new Mayor and former Sheriff, Terry Schrunk, all suffered some negative consequences from the probe. For Purcell and Peterson, the probe meant retirement from public life. For Schrunk it meant the annoyance and humiliation of a public trial for allegedly taking a bribe. Schrunk, of course, survived his trial with his career intact. He became, however, a much more conservative and cautious man (Kell-Uris interview 1981).

Only the racketeer, James Elkins, and his associates felt severe consequences for their crimes. Yet in the end, Elkins, too, successfully fought his conviction. It is generally thought that Elkins' power and income generating ability were broken by the probe he had started.

Because the probe was so limited in its legal consequences for the individuals involved it cannot be shown that what was discovered in Portland is consistent with proposition XII. 
XIII.INFORMAL INTERACTION BETWEEN ORGANIZED CRIME FIGURES AND OTHER ELITES DO EXIST AND ARC USED IN MAINTAINING POLITICAL CONTROL.

The importance of informal interaction between elements of the organized crime community and other elites is clear in the Portland case. Tom Johnson's usefulness both as a bootlegger and as an agent of social control in the black community are examples of a mutually beneficial informal arrangement built on informal interaction. Yet Johnson, in all probability, did not have access to the elites in a sigaificant and ongoing relationship of power or prestige in the manner of Costello (Bell 1960). That distinction would belong to those who were welcomed into the circle of elites who gambled at exclusive clubs and whose friendships extended into the community of the powerful.

In Portland such relationships did exist according to respondents (Kell-Uris interview 1981). The friendship between Al Winters, an entrepreneur in the gambling business, and Gus Soloman, Ray Kell's partner in law practice who went on to become a leading figure in the Schrunk and subsequent Portland city administration, is an excellent example of an informal relationship that could have had a politically significant role.

In this same context, the gatherings at the Bourbon and Ham Club (the old Press Club) in which politicians, newsmen and vice figures drank and talked, is another example of an informal network in operation.

Yet none of these examples constitute an adequate proof of proposition XIII. The first part of the proposition is true in Portland. The second part, that such relationships were used in a significant political control context, was not demonstrated by the material presented. 
XIV. MEDIA ATTENTION AFFECTS PUBLIC CONSCIOUSNESS OF A GIVEN SITUATION:

THIS IN TURN IS A FACTOR IN FORCING ACTION.

The media, as Kell, Thornton, Lambert and Baker (Uris interviews $1981,1980,1979,1980$, respectively) suggested, was instrumental in forcing action in Portland. Much of the visible vice operation and many of its leading figures faded from the public eye. It would be difficult to establish, however, that one version of the incident was favored over the other. In the end, the public retained Terry Schrunk as Mayor. Earlier in May 1956, he won a plurality in the primary election. This was after he was accused of taking a bribe. His acquittal of perjury is seen by Robert Y. Thornton (Thornton-Uris interview 1980) as the turning point of the investigation. It ended the aggressive and continuing inquiry. It destroyed the credibility of James Elkins and, by implication, the story that Elkins told.

The probe was not short lived. It emerged in public in April, 1956, and it survived into the winter of 1957-1958. Cases reiated to the probe were moving through the court system in the 1960 's. Clearly, action was taken because of media attention. It was media attention which caused the governor to act. Governor Elmo Smith ordered the Attorney Generals' intervention and investigation using Multnomah County grand juries. The same exposure brought the event to the attention of the U.S. Senate Select Comnittee on Improper Activities in the Labor or Management Field (1957). The conflict in the media's stories may have been a factor in limiting the amount, form and depth of action taken. The Portland events are therefore consistent with proposition XV.

In examples cited by Gardiner (1970), Miller (1976) and Chambliss (1978), the media's role in calling public attention to alleged vice and 
corruption is emphasized as a factor in the process of exposure and reform. None of these cases deal with a situation quite like Portland's. In Portland the intense rivalry between the two major newspapers in the city during the political struggles of the period produced two very different versions of the problem and who was to blame.

A more general notion suggests itself here: Is it possible that, lacking a consensual model of what was happening, the public found it difficult to believe either version of the story and chose eventually to disregard both?

XV. THE ATTEMPT OF A NEW ELEMENT, SUCH AS A POWERFUL LABOR UNION, TO ALTER EXISTING ARRANGEMENTS AMONG CITY OFFICIALS AND ORGANIZED VICE OPERATORS IS A FACTOR IN CAUSING REFORM.

While media action initiated the vice probe, the alleged attempt of the Teamsters Union through its agents to dominate Oregon and Portland politics influenced the Oregonian decision to publish Elkins' story. It was the same supposed Teamsters takeover at the state level that brought Howard Morgan to the editors of the Oregonian. The allegation that the Teamsters were moving in was the central theme developed during the Hearings of the U.S. Senate Select Committee on Improper Activites in the Labor or Management Field (1957). The outsiders moving in on something local and controllable was a significant factor in the perceptions of Oregonian reporter William Lambert (Lambert-Uris interview 1979). This view was shared by the one-time Attorney General, Robert Y. Thornton (Thornton-Uris interview 1980) and others. That the outsiders were part of a suspect labor union may have had a great ideological significance to the editors of the Oregonian which, with its rich Republican tradition, was certainly not a strong supporter of any aggressive labor union. 
Yet the accommodations, arrangements and understandings among the police and vice operators were critically upset by the heavy-handed style and aggressive tactics of outsiders like Ton Maloney who claimed to be agents of the Teamsters Union.

XVI. WHEN THE SUM OF THE FACTORS REVEALED TO THE PUBLIC IS SUFFICIENTLY

IN VIOLATION OF IMPORTANT MORAL VALUES, PUBLIC MORAL OUTRAGE DEVELOPS. THIS OUTRAGE IS THE BASIS FOR A POPULAR CONSENSUAL DEMAND FOR REFORM.

In Portland there appeared to be little consensus for sweeping reform. The accusations made by Drew Pearson against City Councilman Stanley Earl, which were in effect sustained when Earl lost his libel suit against Pearson, had no apparent political repercussions for Earl. He was reelected to the council as often as he ran.

The charges against Mayors Schrunk and Peterson, never proven and of questionable origin, had limited effect as well. For Peterson, they meant the end of his political career. He ran for office again but was never successful. Yet Schrunk, certainly as tainted as Peterson, went on to finish his political life as a very popular mayor.

As has been stated earlier, the only man who suffered certain harm from the probe was District Attorney William Langley who was removed from office after his conviction for malfeasance. His conviction was later reversed and he returned to the practice of law.

Thus, it may be argued that a popular consensual demand for reform did not materialize in the degree seen during the reform era. The structure of government was unchanged. Few persons were seriously affected who held public office. None of the accused policemen, from the chief down, were convicted or even brought to trial. It is apparent that proposition XV did not hold for Portland in 1956. 
The public evidently did not feel that what was revealed required the sweeping reforms. Either there was no moral value violation of great enough importance or the case was never clearly made that those morals had in fact been seriously compromised.

With the attack upon corruption made by the U.S. Senate Select Committee on Improper Activities in the Labor or Management Field (1957) and with the national publicity that accompanied the attack, many in Portland may have felt that the city's and their own reputation and honor had been hurt. In reaction, it can be argued public attention shifted to a defensive posture. The possibility of serious local corruption became less important than the effort to rally to the defense of the city's reputation. The community may have united against an externally perceived threat, ignoring the original causes for that attack (KaplanUris interview 1979).

This is not to say that there were not changes wrought by the vice probe and expose. The men who claimed to represent the Teamsters fled the city. If the Teamsters really did have ambitions of taking over Oregon politics, this effort failed.

Elkins' power, whatever its extent, was broken along with the arrangements that had developed between the police and the vice operators. A referendum in 1956 ended pinball for two decades. City, county and state politics saw increasing successful involvement by Democrats. As in 1948 , the more visible houses of prostitution, gambling spots and after-hours saloons disappeared.

Portland's almost mythic image as a wide-open city died in the vice probe. While not as sweeping as some, the reform of 1956-1958 in Portland ushered in an era of conservative life style and middle-class virtue. 
A new group came to dominate Portland's economic and political life. This elite emerged at the same time that the vice expose climaxed. It rose to power with the cooperation and active support of Mayor Terry Schrunk. Its members were of a new class of businessmen. While not in agreement on all issues at all times, they included in their ranks men like Ray Kell, who rose with Schrunk, and Ira Keller, who brought to Portland his wealth and know-how. Men such as these served as powerful appointees most notably on the Docks, Port of Portland and Portland Development Commission, where they effectively reshaped the city through massive urban renewal of the downtown core and other areas.

Their perspective was rational and fiscally exemplary. They built a new tax base and a modern concrete, steel and glass city on the rubble of iron fronts and wood frame buildings. Their ideals were in the tradition of progress through growth. The public policies they followed closely paralleled the reform model of the Progressive Era. 


\section{CHAPTER VI}

\section{CONCLUSION}

This dissertation has used the technique of the historical case study to examine a vice probe that took place in the years 1954 to 1958 in Portland, Oregon. The material for the study was gathered from three sources: the mass media; the archives and public documents of the State of Oregon, the City of Portland, Multnomah County and the U.S. Senate; and interviews and papers of those who had an intimate knowledge of the vice situation and the expose.

As public attention focused upon the city, and as national attention followed the sensational local revelations, the careers, lives and power of people important to the scheme of things in Portland seemed under very real threat. But a combination of factors limited the reform effort. There was an eventual reaction of disinterest on the part of the public and the criminal justice system.

The failure of the effort to convict Mayor Terry Schrunk was seen by more than one informant as the turning point in the expose's effort. With that trial, the credibility of the chief informant, James Elkins, was seriously damaged. The cost of the investigation, inept prosecutions and inadequate staff support, together with a consequential lack of convictions, took their toll. Public attention, fickle as always, turned from vice to other problems.

The two contradictory versions of the vice situation in Portland presented by the Oregonian and the Oregon Journal contributed to public 
awareness but also to distrust in the investigative process. The two papers, as we have seen, derived their views from their opposing political perspectives.

For the Oregonian, there was ample evidence of a conspiracy by the Teamsters Union or elements within that Union to take over the local vice scene. This view has much evidence to support it and is upheld by the then Attorney General Robert Y. Thornton and the U.S. Senate Select Committee on Improper Activities in the Labor or Management Field (1957).

For the Oregon Journal the major issue was not the question of an attempted Teamsters takeover, but the vice situation on the local level itself and the honesty of the Oregonian's chief informant. This view has ample support as has been shown by then District Attorney William Iangley, Raymond Kell and others. It was also shared by the jury in the Terry Schrunk perjury trial.

The stories developed by the two rival newspapers were sensational but each was incomplete. Taken together, however, they provided far more information to the public than would one view alone. It is unlikely that a similar divergence of views would gain such a wide audience in Portland today for now there are not two independent and competing daily newspapers in the city.

This dissertation attempts to show how in other places and at other times as well as in Portland in the $1950^{\circ} \mathrm{s}$, vice exposes have been used as devices to alter political power relationships. In this case the reform effort never seized the public imagination to the degree that sweeping local or statewide reforms took place. Instead, the process of change that had marked the post-war years in Portland continued. A popular Democrat, though implicated in the probe, was elected mayor over an incumbent Republican who was similarly accused. 
The group that supported Terry Schrunk as mayor stil: in large part dominates the economic and political life of the city. Yet this group's rise to power appears in retrospect more a reflection of larger economic and political factors than of the vice expose's consequences. As Captain Reiter (Reiter-Uris interview 1980) of the Portland Police Department suggests, the death of the vice scene that existed in the 1940's and $1950^{\prime}$ 's may have had less to do with the revelations of the time than the changing patterns of entertainment and sexual mores that developed in the years that followed.

Even without the prosecution and conviction of all who were implicated, the vice probe had important effects. The efforts of Tom Maloney and others to move into Portland, whether as agents of the Teamsters Union or not, were blocked. The national attention and continued local publicity made it difficult if not impossible for local vice operators and those they allegedly paid off in the police department and other agencies of government to continue with business as usual. This is not to suggest that such relationships are not to be found today by those who are willing to look long and hard. Rather, the specific pattern and extensive payoff system that existed in 1956 was at least disrupted. Without the existence of a multitude of after-hours, liquor, gambling and prostitution houses, the opportunity for graft and corruption at the command level was much reduced.

There is not adequate evidence to prove that there was a single syndicate in control of vice activity in Portland, yet there is ample documentation to warrant the suspicion that such was the case. The local press, the Attorney General's files, the Senate Committee and recent interviews all substantiate this. 
Beyond the question of the syndicate is the issue of those in positions of importance who were linked to the alleged syndicate, those in the legal, business and political elites. The extent of their interconnection remains unestablished in a satisfacory evidential context, yet their interrelationships on an informal basis clearly exist and appear significant.

The failure of the probe to go further could be explained in terms of the power of such a network or cabal to stop the probe. It can also be explained by the contradictory nature of the events. The opposed media versions, the courtroom failures and public disillusionment were all factors.

An historical study such as this cannot establish with any degree of reliability such matters as public attitudes at the time toward vice and corruption, the extent of such corruption, or the reasons behind support for one candidate over another during elective contests involving those implicated in corruption or reform.

Yet the public did express its will through the elective process on two of the issues raised in the expose. In May of 1956 the voters decided for an east side location for the E-R Center (Memorial Coliseum). They also voted to support the city council's decision to make pinball illegal. Both were issues in the vice probe and both were much publicized before the election.

While the triangulation method used in this study helps avoid reliance on one source alone, it has its limits. The recognized unreliability of eye-witnesses, combined with inherent limitations occasioned by personal perspective (the Rashomon effect), as well as the intervening 25 years, take a toll upon accuracy of memory. Documents frequently 
prove equally unreliable or unavailable. All sources are unavoidably biased in almost direct proportion to the degree that such persons or materials reflect closeness to the events under study.

Future scholars would do well to consider an approach involving the task of systematic investigation of corporate and land records as a fourth source in developing histories of this type. While land records were examined in this study, that examination was limited to specific times and places previously mentioned in accounts of the vice probe. Of further use would be an investigation of such records for periods of twenty years bracketing the events under study. These records could reveal the interconnections of business, political, criminal and other elites. Such a search would certainly be quite costly in terms of time and money.

Studies like those of Chambliss (1978), Domhoff (1978) and Gardiner (1975) are crucial in the development of an understanding of how exchange and power in the city actually work. They serve to provide the foundation of understanding that will hopefully lead to the development of a grand theory of governance in the urban context. It is hoped that the present effort, by looking at one case in the Northwest, will aid in developing that foundation. 
Agger, Robert E., Daniel Goldrich, and Bert Swanson. The Rulers and the Ruled. New York: John Wiley \& Sons, 1964.

Allswang, John M. Bosses, Machines, and Urban Voters: An American Symbiosis. Port Washington, New York: Kennikat Press, 1977.

Amick, George, and Barbara Bacon. The American Way of Graft. Princeton, N.J.: The Center for Analysis of Public Issues, 1976.

Anderson, David, and Peter Benjaminson. Investigative Reporting. Bloomington: Indiana University Press, 1976.

Anderson, Robert T.; "From Mafia to Cosa Nostra", American Journal of Sociology, 71 (November 1965), p. 302-310.

Banfield, Edward C., and James Q. Wilson. City Politics. New York: Vintage Books (Alfred A. Knopf, Inc. and Random House, Inc.), 1963.

Becker, Howard S. Outsiders. New York: Free Press, 1963.

Bell, Daniel. The End of Ideology. Glencoe, Illinois: The Free Press, 1960.

Blalock, Hubert M., Jr. Social Statistics: Second Edition. San Francisco: McGraw-Hill Book Company, 1972.

Brandt, Richard M. Studying Behavior in Natural Settings. San Francisco: Holt, Rinehart and Winston, Inc., 1972.

Brown, Andrew Theodore. The Politics of Reform: Kansas City's Municipal Government, 1925-1950. Kansas City, Missouri: Community Studies, Inc., Publication 116, 1958.

Callow, Alexander B., Jr., ed. American Urban History: An Interpretive Reader with Commentaries. New York: Oxford University Press, 1969 .

Calvert, Monte A. "The Manifest Functions of the Machine." In Urban Bosses, Machines, and Progressive Reformers. Ed. Bruce M. Stave. Lexington, Mass.: D.C. Heath and Company, 1972, pp. 45-55.

Campbell, D.T., and D.W. Fiske. "Convergent and Discriminant Validation by the Multitrait-Multimethod Matrix." Psychological Bulletin, 56 (1959), pp. 81-105.

Chambliss, William J. On the Take: From Petty Crooks to Presidents. Bloomington: Indiana University Press, 1978. 
Chambliss, William J., and Richard H. Nagasawa. "On the Validity of Official Statistics: A Comparative Study of White, Black and Japanese High School Boys." The Journal of Research in Crime and Delinquency, No. 6 (January 1969), pp. 71-77.

City Club of Portland. City Club Bulletin, Vol. 28, No. 42 (February 20, 1948).

City Club of Portland. Report on Portland City Government. Portland, Oregon: Portland City Club Bulletin, Voi. 41, No. 51, (1961).

Clinard, Marshall B., and Richard Quinney. Criminal Behavior Systems. New York: Holt, Rinehart and Winston, Inc., 1967.

Coleman, James S. Community Conflict. Glencoe: The Free Press, 1957.

Common Council of the City of Portland. Charter of the City of Portland, and General Ordinances, in Force September, 1866, etc. Portland, Oregon: R.H. Schwab \& Bro., 1886.

Creating Better Cities. Washington, D.C.: U.S. Chamber of Commerce, 1951 .

Cressey, Donald R. Theft of the Nation, New York: Harper \& Row Pub. 1969 (c) Donald R. Cressey.

Dahl, Robert A. Polyarchy: Participation and Opposition. New Haven, Connecticut: Yale University Press, 1971.

Dahl, Robert. Who Governs? Democracy and Power in an American City. New Haven: Yale University Press, 1961.

Dahrendorf, Ralf. Class and Class Conflict in Industrial Society. Stanford, California: Stanford University Press, 1959.

Davis, Kingsley. "Prostitution." In Contemporary Social Problems. Ed. Robert K. Merton and Robert Nisbet. New York: Harcourt, Brace and Janovich, Inc., 1971, pp. 341-351.

Dean, John P., and William Foote Whyte. "What Kind of Truth Do You Get? How Do You Know the Informant is Telling the Truth?" Elite and Specialized Interviewing. Ed. Lewis Anthony Dexter. Evanston, I11: Northwestern University Press, 1970, pp. 119-138.

Dexter, Lewis Anthony. Elite and Specialized Interviewing. Evanston: Northwestern University Press, 1970.

Dumhoff, G. William. Who Really Rules? New Haven and Community Power Reexamined. New Brunswick, New Jersey: Transaction, Inc., 1978.

Douglas, Jack D., ed. Crime and Justice in American Society. Indianapolis: The Bobbs-Merill Company, Inc., 1971. 
Douglas, Jack D. Investigative Social Research: Individual and Team Field Research. Beverly Hills, California: Sage Publications, Inc., 1976.

Gardiner, John A., and Michael A. Mulkey, ed. Crime and Criminal Justice: Issues in Public Policy Analysis. Lexington, Massachusetts: D.C. Heath and Company, 1975.

Gardiner, John A. The Politics of Corruption: Organized Crime in an American City. New York: Russell Sage Foundation, 1970.

Gardiner, John A., and David J. Olson, ed. Theft of the City. Bloomingtoa: Indiana University Press, 1974.

Gibbons, Don C. Society, Crime and Criminal Careers: An Introduction to Criminology. Englewood Cliffs, N.J.: Prentice-Hall, Inc., 1977.

Glaser, Barney G., and Anselm L. Strauss. The Discovery of Grounded Theory: Strategies for Qualitative Research. Chicago: Aldine Publishing Company, 1967.

Gosnell, Harold F. Machine Politics: Chicago Model. Chicago: University of Chicago Press, 1968.

Hayes, Edward C. Power, Structure and Urban Policy: Who Rules Oakland? San Francisco: McGraw-Hill Book Company, 1972.

Hays, Samuel P. Conservation and The Gospel of Efficiency: The Progressive Conservation Movement, 1890-1920. Cambridge, Massachusetts: Harvard University Press, 1959.

Hays, Samuel P. "The Politics of Reform in Municipal Government in the Progressive Era." Pacific Northwest Quarterly, Vol. 55 (Oct. 1964) pp. 157-169.

Hirst, Paul. "Marx and Engels on Law, Crime and Morality." Economy and Society, Vol. 1, No. 1 (February 1972), pp. 28-56.

Holli, Melvin G. Reform in Detroit: Hazen S. Pingree and Urban Politics. New York: Oxford University Press, 1969.

Ianni, Francis A.J., and Elizabeth Reuss-Ianni. A Family Buisness: Kinship and Social Control in Organized Crime. New York: Russel1 Sage Foundation, 1972 .

"Investigations, the Teamsters Take Over." Time Magazine, 18 March 1957, Vol. LXIX, No. 11, p. 25.

Kefauver, Estes. Crime in America. Garden City, N.Y.: Doubleday and Co., 1951. 
Kell, Raymond. "Unpublished and Untitled Legal Brief on James Elkins." Portland, Oregon: n.p., n.d.

Klonoski, James R., and Robert I. Mendelsohn, ed. The Politics of Local Justice. Boston: Little, Brown and Company, 1970.

Lazarfeld, Paul F. and Robert K. Merton. "Mass Communication, Popular Taste and Organized Society Action", In Readings in Social Psychology. Ed. Guy E. Swanson, Theodore M. Newcomb and Eugene L. Hartley. New York: Henry Holt and Company, 1952, pp. 74-85.

Leff, Gordon. History and Social Theory. New York: Doubleday \& Company, Inc., 1969 .

Lewis, Norman. The Honored Society. New York: G.P. Putnam's Sons, 1964.

Lipsky, Michal. "Protest as a Political Resource." The American Political Science Review, Vol. IXII (December 1968, No. 4) PP. 11441158 .

Lubove, Roy. Twentieth Century Pittsburgh: Government, Business and Environmental Change. New York: John Wiley \& Sons, Inc., 1969.

McConnell, Grant. Private Power \& American Democracy. New York: Alfred A. Knopf, 1966.

McCormick, Thomas C., and Roy G. Francis. Methods of Research in the Behavioral Sciences. New York: Harper \& Brothers, Publishers, 1958.

McIntosh, Mary. "The Growth of Racketeering." Economy and Society, Vol. 2, No. 1 (February 1973), pp. 35-69.

McKitrick, Eric L. "The Study of Corruption." The Political Science Quarterly. Vol. LXXII, No. 4 (December 1957), pp. 502-514.

MacColl, E. Kimbark. The Growth of a City: Power and Politics in Portland, Oregon 1915-1950. Portland, Oregon: The Georgian Press, 1976.

Marcuse, Herbert. One Dimensional Man: Studies in the Ideology of Advanced Industrial Society. Boston: Beacon Press, 1964.

Marx, Karl. Capital. New York: International Publishers, 1967.

Marx, Karl. Theories of Surplus Value. London: Lawrence and Wishart Publishers, 1969.

Marx, Karl, and Frederick Engels. Selected Works. New York: International Publishers, 1968. 
Merton, Robert R. Social Theory and Social Structure: Toward the Codification of Theory and Research. Glencoe, Illinois: The Free Press, 1949.

Miller, Walter B. "Youth Gangs in the Crisis Era", In Delinquency, Crime and Society. Ed. James F. Short. Chicago, Ill: University of Chicago Press, 1972.

Miller, Zane L. Boss Cox's Cincinnati: Urban Politics in the Progressive Era. New York: Oxford University Press, 1968.

Mills, C. Wright. The Power Elite. New York: Oxford University Press, 1956.

Morrissey, Charles. "On Oral History Interviewing." In Elite and Specialized Interviewing. Ed. Lewis Anthony Dexter. Evanston, II1.: Northwestern University Press, 1970, pp. 109-118.

Nadel, S.F. "The Interview Technique in Social Anthropology." In The Study of Society. Ed. F.C. Bartlett, et al. London: Kegan Paul, 1939, pp. 217-327.

Nelli, Humbert S. The Italians in Chicago, 1880-1930: A Study in Ethnic Mobility. New York: Oxford University Press, 1970.

Notson, Robert C. Making the Day Begin: A Story of the Oregonian. Portland, Oregon: Oregonian Publishing Company, 1976.

Olsen, Marvin, ed. Power in Societies. New York: The Macmillan Company, 1970.

Parsons, Talcott. The Social System. Glencoe, Illinois: The Free Press, 1951.

Polsby, Nelson W. "How to Study Community Power: The Pluralist Alternative." The Journal of Politics, Vol. 22 (1960), pp. 474484 .

The President's Commission on Law Enforcement and Administration of Justice. The Challenge of Crime in a Free Society. Washington, D.C.: U.S. Government Printing Office, 1967.

Public Administration Service. The City Government of Portland, Oregon. Chicago: Public Administration Service, 1959.

Quinney, Richard. Criminology: Second Edition. Boston: Little, Brown and Company, $1 \overline{969 .}$

Quinney, Richard. Crime and Justice in Society. Boston: Little, Brown and Company, 1969.

Riley, Matilda White. Sociological Research: A Case Approach. New York: Harcourt, Brace \& World, Inc., 1963. 
Riorōon, William L. Plunkitt of Tammany Hall. Hew York: E.P. Dutton \& Co., Inc., 1963.

"Round Up Time in Portland." Time Magazine, 8 April 1957, Vol. IXIX, No. 14; . 20.

Schiavo, Giovanni. The Truth About the Mafia. New York: Vigo Press, 1962.

Schiesl, Martin J. The Politics of Efficiency: Municipal Administration and Reform in America 1800-1920. Berkeley: University of California Press, 1977.

Selltiz, Clair, Marie Jahoda, Morton Deutsch, and Stuart W. Cook. Research Methods in Social Relations: Revised. Henry Holt and Company, Inc., 1959.

Shank, Alan. Political Power and the Urban Crisis: 2nd Edition. Boston: Holbrook Press, Inc., 1973.

Sherman, Laurence W. "Towards a Sociological Theory of Police Corruption." In Police Corruption, A Sociological Perspective. Ed. Laurence W. Sherman. Garden City, N.Y.: Anchor Press, 1974, pp. 146.

Sieber, S.D. "The Integration of Field Work and Survey Methods." The American Journal of Sociology, 78 (May 1973), pp. 1335-1359.

Smith, H.W. Strategies of Social Research: The Methodological Imagination. Englewood Cliffs, N.J.: Prentice-Hall, Inc., 1975.

Spitzer, Stephen P. "Towards a Marxian Theory of Deviance." Paper read at the A.S.A. Convention, August 1975. A revised and shorter version was later published in: Social Problems, Vol. 22, No. 5 (1975) pp. 638-651.

Stave, Bruce M. The New Deal and the Last Hurrah: Pittsburgh Machine Politics. Pittsburgh: University of Pittsburgh Press, 1970 .

Stave, Bruce M., ed. Urban Bosses, Machines and Progressive Reformers. Lexington, Massachusetts: D.C. Heath and Comany, 1972.

Steffens, Lincoln. The Autobiography of Lincoln Steffens. New York: Harcourt, Brace and Company, Inc., 1931.

Steffens, Lincoln. The Shame of the Cities. New York: McClure, Phillips \& Co., 1904.

Stinchcombe, Arthur L. Constructing Social Theories. San Francisco: Harcourt, Brace \& World, Inc., 1968.

Tarr, Joel A. "The Urban Politician as Entrepreneur." In Urban Bosses, Machines and Progressive Reforms. Ed. Bruce Stave. Lexington, Massachusetts: D.C. Heath and Company, 1972, pp. 62-72. 
U.S. Bureau of the Census. U.S. Census of Population: 1940. Vol. II, Characteristics of the Population; Parts 5 (California), 11 (Georgia), 32 (New York), and 37 (Oregon). U.S. GPO, Washington D.C., 1941 .

U.S. Bureau of the Census. U.S. Census of Population: 1950. Vol. II, Characteristics of the Population; Parts 5 (California), 11 (Georgia), 32 (New York), and 37 (Oregon). U.S. GPO, Washington D.C., 1952.

U.S. Bureau of the Census. U.S. Census of Population: 1960. Vol. II, Characteristics of the Population; Parts 5 (California), 11 (Georgia), 32 (New York), and 37 (Oregon). U.S. GPO, Washington D.C., 1963.

U.S. Cong. Senate. Select Committee on Improper Activities in the Labor or Management Field. Hearings Before the Select Committee on Improper Activities in the Labor or Management Field. $85 \mathrm{th}$ Congress, lst sess., Parts 1-4, Feb.-Mar. 1957.

U.S. Department of Justice. Law Enforcement Assistance Administration. National Advisory Committee on Criminal Justice Standards and Goals. Organized Crime: Report of the Task Force on Organized Crime. Washington D.C.: Government Printing Office, 1976.

Wade, Richard C. "Urbanization." In The Comparative Approach to American History.. Ed. C. Vann Woodward. New York: Basic Books, Inc., 1968, Section IV of Chapter 14. Rpt. "The Periphery Versus the Center." In Urban Bosses, Machines and Progressive Reformers. Ed. Bruce M. Stave. Lexington, Mass.: D.C. Heath and Company, 1972, pp. 75-80.

Webb, Eugene J., Donald T. Campbell, Richard D. Schwartz, and Lee Sechrest. Unobtrusive Measures: Nonreactive Research in the Social Sciences. Chicago: Rand McNally \& Company, 1966.

Weinstein, James. The Corporate Ideal in the Liberal State: 1900-1918 1918. Boston: Beacon Press, 1968.

Willems, Edwin P., and Harold L. Rausch, ed. Naturalistic Viewpoints in Psychological Research. San Francisco: Holt, Rinehart and Winston, Inc., 1969.

Wilson, James Q., ed. City Politics and Public Policy. New York: John Wiley \& Sons, Inc., 1968 .

Wirt, Frederick M. Power in the City: Decision Making in San Francisco. Berkeley: University of California Press, 1974.

Wolfinger, Raymond E. The Politics of Progress. New Jersey: PrenticeHall, Inc., 1974. 
Zink, Harold. City Bosses in the United States: A Study of Twenty Municipal Bosses. Durham, North Carolina: Duke University Press, 1930 .

\author{
NEWSPAPER ARTICIES \\ (CHRONOLOGICALIY)
}

THE OREGON JOURNAL

Anon. "Riley wants grand jury quiz." Oregon Journal, 15 February 1948, p. 1 , col. 8 .

Anon. "Mayor contends City Club Report on Law Enforcement Ill Grounded." Oregon Journal, 15 February 1948, p. 4, col. 1.

Williams, Brad, and Rolla Crick. "Governor acts on vice scandal charges." Oregon Journal, 19 April 1956, p. 1, col. 8.

Anon. "Langley admits Teamster support." Oregon Journal, 19 April 1956, p. 4, col. 2 .

Anon. "Langley calls quiz, Governor acts, Crosby quits E.R., Probe lists Peterson, Purcell." Oregon Journal, 20 April 1956, p. 1, col. 7.

Anon. "Thornton rebuffed in vice raid plea." Oregon Journal, 20 April 1956, p. 4, col. 3.

Williams, Brad, and Doug Baker. "Langley cries blackmail." Oregon Journal, 21 April 1956, p. 1, col. 7

Anon. "Vice probe fireworks fly." Oregon Journal, 21 April 1956, p. 1, col. 8

Anon. "Only way to clear air." Oregon Journal, 21 April 1956, p. 4, col. 1 .

Anon. "Governor 0.K.'s Thornton quiz." Oregon Journal, 22 April 1956, p. 1 , col. 7 .

Baker, Doug. "Langley rejects resignation hint." Oregon Journal, 23 April, 1956, p. 1, col. 8.

Anon. "Vice study postponed to May 7." Oregon Journal, 24 April 1956, p. 1 , col. 6 .

Baker, Doug. "Mystery man Elkins known in many circles." Oregon Journal, 24 April 1956, p. 1, col. 3.

Anon. "Warning issued by Thornton." Oregon Journal, 25 April 1956, p.1, col. 7. 
Anon. "Thornton prepares vice probe." Oregon Journal, 26 April 1956, p.1, col. 4 .

Anon. "Amnesty for Elkins sought says Schrunk." Oregon Journal, 5 May 1956, p. 1, col. 2 .

Anon. "Public vice quiz asked by Langley." Oregon Journal, 6 May 1956, p. 1., col. 2 .

Anon. "Card rooms closed." Oregon Journal, 7 May 1956, p. 1, col. 5.

Anon. "Raid seized tapes due for vice probe role." Oregon Journal, 18 May 1956, p. 1, col. 6 .

Langley, William M. "Langley tells his version of the vice story." Oregon Journal, 23 July 1956, p. 1, col. 1.

Langley, William M. "D.A. details how threats upset family." Oregon Journal, 24 July 1956, p. 1, col. 2.

Langley, William M. "Langley sees Elkins 'trap' in vice quiz." Oregon Journal, 25 July 1956, p. 1, col. 1.

Anon. "Clark raid not legal." Oregon Journal, 18 September 1956, p. 3, col. 5 .

Williams, Brad. "Police seek 2 women tied to Clark robbery." Oregon Journal, 3 October 1956, p. 1, col. 3 .

Anon. "Vice case drags in court." Oregon Journal, 6 November 1956, p. 1 , cols. 2 and 7.

Crick, Rolla. "First vice probe trial opens." Oregon Journal, 5 December 1956, p. 1, col. 8.

Anon. "Nance case rested." Oregon Journal, 10 December 1956, p. 1, col. 2.

Baker, Doug. "Judge halts vice trial." Oregon Journal, 11 December 1956, p. 1, col. 7 .

Anon. "Vice probe trial costs get study." Oregon Journal, 15 December 1956, p. 2, col. 4.

Anon. "Teamster records subpoenaed." Oregon Journal, 19 December 56, p. $1, \operatorname{col}$. 1 .

White, John. "City asks Teamster quiz." Oregon Journal, 21 December 1956, p. 1, col. 1 .

Williams, Brad. "Vice probe perjury attempt reported." Oregon Journal, 31 December 1956, p. 1, col. 4. 
Anon. "Vice quiz indictment attacked." Oregon Journal, 9 January 1957, p. 2, col. 3 .

Anon. "Vice jury testimony jails policeman." Oregon Journal, 10 January 1957, p. 1, col. 4.

Anon. "Judge eyes vice quiz indictment." Oregon Journal, 23 January 1957, p. 1, col. 7 .

Anon. "Vice jury acts." Oregon Journal, 24 January 1957, p. 1A, col. 5.

Anon. "Recordings doctored D.A. claims." Oregon Journal, 28 January 1957, p. 1, col. 1 .

Anon. "Jury hears Teamster." Oregon Journal, 29 January 1957, p. 1, col. 1 .

Anon. "Wire tap evidence way cleared." Oregon Journal, 5 February 1957, p. $1 \mathrm{~A}, \mathrm{col} .8$.

Anon. "Schrunk held by jury second day." Oregon Journal, 15 March, 1957 , p. 1, col. 5.

Anon. "Grand jury votes 9 indictments." Oregon Journal, 16 March, 1957, p. 1 , col. 7 .

Crick, Rolla. "Bribe tale discounted." Oregon Journal, 18 March 1957, p. 1, col. 8.

Anon. "Elkins date shifted." Oregon Journal, 20 March 1957, p. 1, col. 6.

Baker, Doug. "Committee to defend our Mayor." Oregon Journal, 2 April 1957, p. 1, col. 5.

Crick, Rolla J. "Hatcheck gril repeats envelope story." Oregon Journal, 4 April 1957, p. 1, col. 8.

Anon. "Timed raids hit Portland niteries - Four Portland nitespots hit." Oregon Journal, 6 April 1957, p. 1, col. 7.

Anon. "Time distorts facts." Oregon Journal, 8 April 1957, Sec. 4, p. 4 , col. 1 .

Anon. "Let's look at the facts: Press role in probe given in true light." Oregon Journal, 8 April 1957, p. 1, col. 1.

Anon. "Two secret indictments returned." Oregon Journal, 9 April 1957, p. 1, col. 4 .

Anon. "Let's look at the facts: Sharp contrast seen in papers' positions." Oregon Journal, 9 April 1957, p. 1, col. 1. 
Anon. "Let's look at the facts: Events leading up to tape case told." Oregon Journal, 10 April 1957, p. 1, col. 1.

Anon. "Elkins says Langley took charity gambling cut." Oregon Journal, 11 April 1957, p. 1, col. 2.

Anon. Schrunk testifies on seized Elkins tapes." Oregon Journal, 11 April 1957, p. 2, col. 6 .

Anon. Elkins connection denied by Langley." Oregon Journal, 12 April 1957, p. 1, col. 2 .

Anon. "F.B.I. seizure of wiretaps held legal." Oregon Journal, 12 April 1957 , p. 1, col. 8 .

Anon. "Let's look at the facts." Oregon Journal, 14 April 1957, p. 1, col. 1 .

Anon. "Langley guilty - faces removal." Oregon Journal, April 1957 , p. 1, col. 7 .

Anon. "Jury convicts Elkins, Clark." Oregon Journa1, 12 May 1957, p. 1, col. 8 .

Anon. "Elkins meted 20 month sentence." Oregon Journal, 21 May 1957, p. 1, co. 7 .

Auon. "Witness intimidation Elkins' purpose." Oregon Journal, 24 May 1957, p. 3, col. 7 .

Anon. "News prejudice court ban asked." Oregon Journal, 7 June 1957, p. $1, \operatorname{col} .2$.

Anon. "Schrunk defense looses try for dismissal, wins point." Oregon Journal, 19 June 1957, p. 3, col. 5.

Crick, Rolla J. "Hatcheck girl repeats envelope story." Oregon Journal, 19 June 1957, p. 1, col. 7.

Anon. "Never dope addict." Oregon Journal, 20 June 1957, p. 2, col. 7.

Crick, Rolla J. "Deputy tells of cash pick up." Oregon Journal, 20 June 1957 , p. 1, col. 7 .

Crick, Rolla J. "State rests in Schrunk case." Oregon Journal, 21 June 1957, p. 1, col. 7 .

Crick, Rolla J. "Vice czar tied to use of dope." Oregon Journal, 22 June 1957, p. 1, col. 8.

Crick, Rolla J. "Jim Elkins' man admits drawing Oregonian checks past year." Oregon Journal, 24 June 1957, p. 1, col. 7 . 
Crick, Rolla J. "Story switched; bribe 'seen' again." Oregon Journal, 25 June 1957, p. 1, col. 7.

Anon. "Schrunk trial defense rests." Oregon Journal, 27 June 1957, p. $1, \operatorname{col} .7$.

Baker, Doug. "Jury hears attorneys final arguments as trial of Mayor nears decision." Oregon Journal, 28 June 1957, p. 1, col. 5.

Crick, Rolla J. "Jury acquits Schrunk." Oregon Journal, 29 June 1957, p. 1 , col. 7 .

Anon. "A man terribly wronged." Oregon Journal, 29 June 1957, p. 8, col. 1 .

Anon. "Thornton vice quiz on state." Oregon Journal, 3 July, 1957, p. 1, col. 1 .

Anon. "Thornton, D.A. argue action." Oregon Journal, 3 July 1957, p. 1, col. 1 .

Chenoweth, Art. "Jury acquits policeman." Oregon Journal, 13 July 1957, p. 1, col. 4 .

Anon. "Elkins word not good enough." Oregon Journal, 18 July 1957, Sec. 4, p. 4, col. 1 .

Baker, Doug. "Grange attacks trial laxity." Oregon Journal, 25 July 1957 , p. 2A, col. 6 .

Anon. "Time won by Elkins." Oregon Journal, 5 August 1957, p. 1, col. 7.

Anon. "Three Langley cases killed." Oregon Journal, 6 August 1957, p. 2 , col. 4 .

Anon. "Vice jury policemen cases out." Oregon Journal, 20 August 1957, p. $1, \operatorname{col} .8$.

Anon. "Old vice cases die." Oregon Journal, 28 August 1957, p. 4, col. 3.

Anon. "Extortion indictments latest to fall apart." Oregon Journal, 30 August 1957, p. 1, col. 3.

Anon. "Call girl defendant on trial." Oregon Journal, 4 September 1957, p. 3, col. 2 .

Anon. "Four vice cases out." Oregon Journal, 4 September 1957, p. 3, col. 3 .

Ostergen, Jack. "Ex-call girl clams up." Oregon Journal, 5 September 1957, p. 1, col. 4. 
Anon. "Howlett's trial fails to start." Oregon Journal, 9 September 1957, p. 4, col. 3 .

Anon. "Schrunk cleared of final indictment." Oregon Journal, 17 September 1957, p. 1, col. 8.

Anon. "Vice probe back on track." Oregon Journal, 19 September 1957, Sec. 4, p. 4, col. 1 .

Anon. "Howlett charges dismissed." Oregon Journal, 21 September 1957, p. 1 , col. 3 .

Anon. "Maloney conspiracy trial delay sought." Oregon Journal, 23 September 1957, p. 3, col. 6 .

Anon. "Indictments of 5 cops on way out." Oregon Journal, 24 September 1957 , p. 1 , col. 5 .

Anon. "Indictments of Langley, Elkins out." Oregon Journal, 28 September 1957, p. 2, col. 1.

Anon. "Probe costs now about $\$ 120,000 . "$ Oregon Journal, 30 September 1957, p. 1, col. 7 .

Baker, Doug. "Elkins pleads Fifth." Oregon Journal, 30 September 1957, p. $1, \operatorname{col} .8$.

Anon. Pictures. Oregon Journal, 1 October 1957, p. 2, col. 7.

Anon. "The discredited vice czar." Oregon Journal, 1 October 1957, Sec. 4, p. 4, col. 1 .

Anon. "Elkins plea hearing set." Oregon Journal, 20 November 1957, p. $1, \operatorname{col} .4$.

Anon. "Court hears Elkins quash plea." Oregon Journal, 27 November 1957, p. 1, col. 1 .

Anon. "Assøciate of Elkins requests jury trial." Oregon Journal, 29 November 1957, p. 2, col. 2 .

Anon. "Elkins asked to pay fine." Oregon Journal, 24 December 1957, p. $3, \operatorname{col}$. 1 .

Anon. "Police subpoena Elkins and Clark." Oregon Journal, 25 January 1958 , p. 1, col. 1 .

Anon. "Three more Portland vice charges dropped." Oregon Journal, 28 January 1958, p. 1, col. 6 .

Anon. "Time needed for clear answers." Oregon Journal, 30 January 1958, Sec. 4, p. 4, col. 1 . 
Anon. "Door smashed, vice squad nets 15." Oregon Journal, 15 February 1958 , p. 1, col. 3 .

Anon. "Vice quiz indictment contested." Oregon Journal, 19 March 1958, p. 1 , col. 7 .

Baker, Doug. "Quiz blasts union vice tie up." Oregon Journal, 25 March 1958 , p. 1, col. 7 .

Running, Jim. "Elkins, pal get time for appeal." Oregon Journal, 26 March 1958, p. 1, col. 2.

Anon. "Elkins loan costs U.S. agent job." Oregon Journal, 5 April 1958, p. 1 , col. 1 .

Baker, Doug. "Elkins dope warrant not served." Oregon Journal, 6 April 1958, p. $1, \operatorname{col} .8$.

Anon. "Last E1kins indictment ruled out." Oregon Journal, 22 April 1957, p. 1, col. 4 .

Anon. "Thornton fights for Elkins indictment." Oregon Journal, 23 April 1958 , p. 1, col. 8 .

Pearson, Drew. "Portlnd vice quiz proves fizzle." Oregon Journal, 23 April 1958, Sec. 4, p. 4, col. 4.

Anon. "Elkins gets new delay." Oregon Journal, 24 April 1958, p. 2, col. 5 .

Anon. "Elkins case transcript gets study." Oregon Journal, 5 May 1958, p. $1, \operatorname{col} .4$.

Anon. "Exhibits on way to court." Oregon Journal, 24 May 1958, p. 2, col. 1 .

Baker, Doug. "Elkins aides charges in Shaledon racket." Oregon Journal, 4 June 1958, p. 1, col. 7.

Anon. "10 Elkins indictments cleared for dismissal." Oregon Journal, 10 July 1958, p. 2, col. 5.

Baker, Doug. "Report on Elkins drug use secret." Oregon Journal, 18 July 1958, p. 1, col. 6 .

Baker, Doug and Hank Kane. "Jury probes Elkins vice set up." Oregon Journal, 29 September 1958, p. 1, col. 7.

Kane, Hank. "Jury calls officers." Oregon Journal, 30 September 1958, p. 1 , col. 5 .

Anon. "Oregonian twists, distorts." Oregon Journal, 30 September, Sec. $4, \overline{\text { p. } 4, \text { col. } 1 .}$ 
Baker, Doug. "Elkins gang named in safe plot." Oregon Journal, 2 October 1958, p. 1 , col. 4 .

Anon. "Diversion from real issue." Oregon Journal, 7 October 1958, Sec. 4, p. 4, col. 1 .

Anon. "Senate probers subpoena Elkins again." Oregon Journal, 10 October 1958, p. 1, col. 7 .

Anon. "Elkins files law suit." Oregon Journal, 14 October 1958, p. 11B, col. 4.

Ostergren, Jack. "Vice jurors hear former mayor, chief." Oregon Journal, 17 October 1958 , p. 1, col. 1 .

Crick, Rolla. "Elkins off to Senate quiz." Oregon Journal, 22 October 1958, p. 2D, col. 1 .

Anon. "Elkins trial 0.K. fought." Oregon Journal, 23 October 1958, p. 15A, col. 7 .

Anon. "Elkins due for jury on Monday." Oregon Journal, 24 October 1958, p. 2B, col. 1 .

Anon. "D.C. jury quiz aims at Oregon." Oregon Journal, 27 October 1958, p. $1, \operatorname{col} .6$.

Roulhac, Hamilton. "Indictment of Crosby quiz goal." Oregon Journal, 28 October 1958, p. 1, col. 3 .

Anon. "One of last vice quiz indictments dismissed." Oregon Journal, 28 October 1958, p. 2C, col. 2 .

Anon. "Vice expose draws barbs of Thornton." Oregon Journal, 31 October 1958, p. 1, col. 1 .

Anon. "Thornton specific on charges." Oregon Journal, 1 November 1958, p. 2 , col. 1 .

Anon. "Case lost, vice court down to 10" Oregon Journal, 11 November 1958 , p. 2B, col. 5 .

Anon. "Indictments of Elkins upheld." Oregon Journal, 12 November 1958, p. $1, \operatorname{col} .4$.

Anon. "County starts Thornton court house ouster." Oregon Journal, 9 December 1958, p. 1, col. 4.

Baker, Doug. "State urges 2 more vice cases killed." Oregon Journal, 12 December 1958, p. 1, col. 2 .

Anon. "Thornton accuses 2 Oregonian newsmen of hatchet job threat." Oregon Journal, 17 December 1958, p. 1, col. 4. 
Anon. "Elkins appeal due." Oregon Journal, 2 February 1959, p. 1, col. 6.

Anon. "Last two indictments of Langley dismissed." Oregon Journal, 24 March 1959, p. 1, col. 5.

Baker, Doug. "Elkins, Clark wiretap appeal denied." Oregon Journal, 28 April 1959, p. 1, col. 8.

Anon. "High court sustains Elkins plea." Oregon Journal, 27 May 1959, p. $2 \mathrm{~A}, \mathrm{col} .5$.

Anon. "Court rules for Langley." Oregon Journal, I July 1959, p. 1, col. 6.

Baker, Doug. "Long trial of Elkins underway." Oregon Journal, 19 October 1959, p. 1, col. 6 .

Baker, Doug. "Officer's wife can't sit on jury." Oregon Journal, 20 October 1959, p. 1, col. 2.

Baker, Doug. "Two-state manhunt for key witness." Oregon Journal, 27 October 1959, p. 1, col. 1 .

Baker, Doug. "Judge acquits Elkins of conspiracy." Oregon Journal, 5 November 1959, p. 1, col. 8.

Anon. "Conviction of Elkins set aside." Oregon Journal, 27 January 1960 , p. 1, col. 8.

Anon. "Elkins narcotics conviction upheld." Oregon Journal, 28 December 1966, p. 15, col. 6.

Anon. "Ex-vice kingpin here killed in car crash." The Oregon Journal, 10 0ct. 1968, p. 1, col. 7 .

\section{THE OREGONIAN}

Anon. "Portland police protection of vice, gambling charged." Oregonian, 15 February 1948, p. 1, col. 5.

Anon. "Brown denies alibi of Riley." Oregonian, 16 February 1948, p. 1, col. 7 .

Anon. "District Attorney working with City Club in investigating alleged organized vice." Oregonian, 17 February 1948, p. 1, col. 3.

Anon. "Mayor disputes jury findings on wartime vice." Oregonian, 4 April 1948, p. 22, col. 7. 
Anon. "Cab chiefs---city wide open." Oregonian, 2 Aug. 1953, p. 1, col. 6.

Anon. "'Houses' found open but Mayor discounts charge of syndicate." Oregonian, 3 Aug. 1953, p. 1, col. 6.

Turner, Wallace, and William Lambert. "City, county control sought by gamblers." Oregonian, 19 April 1956, p. 1, col. 1.

Turner, Wallace, and William Lambert. "Profit making pact tied to E-R Center options." Oregonian, 20 April 1956, p. 1, col. 1.

Hauser, Paul. "Mayor directs Teamster to quit E-R. Governor Smith holds vice parley." Oregonian, 20 April 1956, p. 1, col. 5.

Turner, Wallace, and William Lambert. "D.A. close to gambling group." Oregonian, 21 April 1956, p. 1, col. 7.

Hanson, Keith. "Vice quiz press subpoenas delayd." Oregonian, 21 April 1956 , p. 1 , col. 4 .

Anon. "Langley told of violation." Oregonian, 21 April 1956, p. 5, col. 1.

Anon. "Expose getting results." Oregonian, 21 April 1956, p. 8, col. 1.

Turner, Wallace and William Lambert. "Control of pinball trade by Teamsters seen." Oregonian, 22 April 1956, p. 1, col. 1.

Anon. "Governor to ask Thornton to conduct probe." Oregonian, 22 April 1956 , p. 1, col. 7 .

Anon. "Subpoena brings Elkins." Oregonian, 22 April 1956, p. 35, col. 1 .

Turner, Wallace and William Lambert. "Teamster chiefs build political machinery." Oregonian, 23 April 1956, p. 1, col. 1.

Anon. "Quick action in probe plan of Thornton." Oregonian, 23 April 1956, p. 1, col. 7 .

Anon. "Langley charges story distorts." Oregonian, 23 April 1956, p. 16 , col. 1 .

Anon. "Portland racket plot follows national pattern/Political lines, use of boycott common tools." Oregonian, 24 April 1956, p. 1, col. 1.

Anon. "Crosby holds up counterblast/Langley refuses to resign." Oregonian, 24 April 1956, p. 1, col. 5.

Turner, Wallace, and William Lambert. "Elkins, Langley, Crosby amity rift traced - 3 linked via politics, business deals." Oregonian, 25 April 1956, p. 1, col. 1. 
Anon. "State probe into rackets set in motion." Oregonian, 25 April 1956, p. 1, col. 8 .

Anon. "Facts speak for themselves." Oregonian, 25 April 1956, p. 18, col. 1 .

Anon. "Crosby resigns campaign/CIO body supports Earl." Oregonian, 26 April 1956, p. 1, col. 5.

Anon. "Vice probe scope set by Smith." Oregonian, 27 April 1956, p. 1, col. 1 .

Turner, Wallace and William Lambert. "D.A., bookie plot to oust Chief, set up vice." Oregonian, 30 April 1956, p. 1, col. 1 .

Anon. "Recorded room conversation reveals plot of D.A., bookie." Oregonian, 30 April 1956, p. 12, col. 1.

Anon. "Thornton questions newsmen." Oregonian, 1 May 1956, p. 1, col. 4.

Anon. "Insulate the Grand Jury." Oregonian, 1 May 1956, p. 14, col. 1.

Turner, Wallace and William Lambert. "Labor strife seen as club over local papers." Oregonian, 4 May 1956, p. 1, col. 2.

Anon. "Blast directed at advertising in linking 'revenue' to pinball ballot measure." Oregonian, 4 May 1956, p. 1, col 2.

Anon. "Full inquiry in vice goal of Oregonian." Oregonian, 5 May 1956, p. 1 , col. 1 .

Anon. "Racket probe time raised by Thornton." Oregonian, 6 May 1956, p. 1 , col. 1 .

Anon. "Pressure try told by Morgan." Oregonian, 6 May 1956, p. 1, col 4.

Anon. "State denies inactivity." Oregonian, 6 May 1956, p. 11.

Turner, Wallace, and William Lambert. "Tape recordings' role in crime." Oregonian, 8 May, 1956, p. 1, col. 1 .

Turner, Wallace and William Lambert. "Downfall of Thornton aim of crime plotters." Oregonian, 9 May 1956, p. 1, col. 1.

Turner, Wallace and William Lambert. "Attempt bared to use Grand Jury." Oregonian, 11 May 1956, p. 1, col. 1.

Anon. "Tape raid tip denied by Herder." Oregonian, 22 May 1956, p. 1, col. 1 .

Anon. "Witnesses indicted in wiretap." Oregonian, 23 May 1956, p. 1, col. 8 . 
Anon. "Let's have all evidence." Oregonian, 8 June 1956, p. 26, col. 1.

Maloney, Thomas. "Maloney tells of connection with attempted vice setup." Oregonian, 20 June 1956, p. 13, col. 1.

Anon. "D.A. passes call by jury." Oregonian, 19 June 1956, p. 19, col. 2.

Anon. "Key figure in inquiry contacted." Oregonian, 20 June 1956, p. 1, col. 4.

Turner, Wallace. "Dynamite put in car of Elkins." Oregonian, 7 July 1956 , p. 1, col. 8 .

Anon. "Langley, Purcell asked to volunteer testimony.: Oregonian, 13 July 1956, p. 1, col. 7.

Anon. "D.A. skips Grand Jury invite." Oregonian, 14 July 1956, p. 1, col. 5 .

Anon. "Ousted sheriff heard by jury." Oregonian, 18 July 1956, p. 1, col. 2 .

Anon. "Key witness policeman weighs act." Oregenian, 7 August 1956, p. 1 , col. 7 .

Turner, Wallace. "Editor traces Elkins." Oregonian, 10 August 1956, p. $17, \mathrm{col} .4$.

Anon. "D.A. smashes camera, 29 accused arraigned." Oregonian, 11 August 1956 , p. 1, col. 5 .

Lambert, William. "F.B.I. seizes Clark tapes." Oregonian, 6 September 1956, p. 1, col. 1 .

Anon. "Langley asked to help." Oregonian, 8 September 1956, Sec. 3, p. $4, \operatorname{col} .5$.

Anon. "D.A. joins in seeking dismissal." Oregonian, 12 September 1956, p. 1 , col. 4 .

Anon. "Mayor, Sheriff hurl charges." Oregonian, 16 September 1956, p. 1 , col. 7 .

Anon. "Harassment of Thornton." Oregonian, 3 October 1956, p. 18, col. 2.

Anon. "Four policemen to face trial." Oregonian, 12 October 1956, p. 1, col. 4 .

Anon. "Vice investigation trial set." Oregonian, 24 October 1956, p. 1, col. 6 . 
Anon. "Jury leak probe." Oregonian, 25 October 1956, p. 1, col. 1.

Anon. "Evidence due in vice probe." Oregonian, 27 November 1956, p. 1, col. 5 .

Anon. "Vice inquiry resumes." Oregonian, 5 December 1956, p. 1, col. 6.

Anon. "Five policemen indicted." Oregonian, 7 December 1956, Sec. 3, p. 16 , col. 3 .

Anon. "Nance contradicts State Police." Oregonian, 11 December 1956, p. 16 , col. 1 .

Anon. "Judge dismisses perjury charge." Oregonian, 12 December 1956, p. $1, \operatorname{col} .4$.

Turner, Wallace. "Teamster records subpoenaed." Oregonian, 19 December 1956, p. $1, \operatorname{col} .6$.

Anon. "Thornton outlines status of indictments." Oregonian, 28 December 1956, p. 11, col. 1 .

Anon. "Vice trial block fails." Oregonian, 20 December 1956, p. 1, col. 8.

Turner, Wallace, and William Lambert. "Vice case figure surrenders." Oregonian, 1 January 1957, p. 1, col. 6.

Anon. "Delay given Langley." Oregonian, 17 January 1957, Sec. 3, p. 8, col. 3.

Anon. "Judge denies writs." Oregonian, 22 January 1957, p. 1, col. 6.

Anon. "Jury transcript ordered." Oregonian, 23 January 1957, Sec. 2, p. 6 , col. 3 .

Anon. "Judge orders new start on indictment of D.A." Oregonian, 26 January 1957, p. 1, col. 4.

Anon. "Grand jury reconvenes." Oregonian, 30 January 1957, p. 15, col. 3.

Anon. "Thornton denies ordering tape editing." Oregonian, 1 February 1957, p. 1, col. 2.

Anon. "Vice probe to continue." Oregonian, 2 February 1957, p. 1, col. 5.

Anon. "Grand jury hears Elkins." Oregonian, 7 February 1957, p. 1, col. 3.

Anon. "Clobbering witnesses." Oregonian, 8 February 1957, p. 18, col. 1. 
Anon. "Motion filed in court to quash vice indictments." Oregonian, 22 February 1957, Sec. 3, p. 9, col. 5.

Loebb, David. "Police nab 7 in vice raid." Oregonian, 26 February 1957, p. 1 , col. 7 .

Smith, Robert. "Oregonian team of reporters charges politico rig." Oregonian, 27 February 1957, p. 1, col. 3.

Anon. "Elkins bares '54 Langley deal." Oregonian, 27 February 1957, p. 1, col. 7 .

Anon. "Portland madam testifies." Oregonian, 6 March 1957, p. 1, col. 3.

Anon. "Dice game goes ahead." Oregonian, 10 March 1957, p. 41, col. 2.

Anon. "Elkins, Clark delay trial." Oregonian, 19 March 1957, p. 11, col. 1 .

Anon. "Schrunk's record: he should resign." Oregonian, 30 March 1957, p. 10, col. 1 .

Anon. "Schrunk arraigned on counts." Oregonian, 4 April 1957, p. 1, col. 3.

Sullivan, Ann. "Jury adds perjury to counts." Oregonian, 10 April, 1957 , p. I, col. 8 .

Anon. "Abatement move hinted." Oregonian, 10 April 1957, p. 17, col. 5.

Anon. "Not guilty says Mayor." Oregonian, 13 April, 1957, p. 1, col. 1.

Sullivan, Ann. "Elkins, Clark guilty." Oregonian, 12 May 1957, p. 1, col. 7 .

Anon. "Strong case Elkins racketeering." Oregonian, 13 May 1957, p. 1, col. 1 .

Sullivan, Ann. "Fines, jail sentences." Oregonian, 22 May 1957, p. 1, col. 1 .

Anon. "Press gag bid filed for Mayor." Oregonian, 7 June 1957, p. 1, col. 1 .

Sullivan, Ann. "News curb court plea fails test." Oregonian, 11 June 1957, p. 1 , col. 6 .

Sullivan, Ann. "Jury chosen for Schrunk prejury trial." Oregonian, 18 June 1957, p. 1, col. 8.

Sullivan, Ann. "State claims Schrunk told lie, defense charges political plot." Oregonian, 18 June 1957, p. 1, col. 5. 
Sullivan, Ann. "Elkins says Schrunk 0.k.'d illegal activities." Oregonian, 20 June 1957, p. 1, col. 7.

Sullivan, Ann. "Witnesses tell of 'Donations' to Schrunk for convention." Oregonian, 21 June 1957, p. 1, col. 4.

Sullivan, Ann. "Schrunk witness says no gambling, drinks seen in raid." Oregonian, 22 June 1957, p. 1, col. 6.

Sullivan, Ann. "Clark says Bennett told him of paying Schrunk $\$ 500$ bribe." Oregonian, 25 June 1957, p. 1, col. 6 .

Sullivan, Ann. "Bribe, plots seen by two witnesses in Schrunk trial." Oregonian, 26 June 1957, p. 1, col. 6.

Sullivan, Ann. "Schrunk swears no bribe taken; Senate probe council testified." Oregonian, 27 June 1957, p. 1, col. 3.

Sullivan, Ann. "Schrunk perjury case to go to jury Friday, mistrial move over Kennedy denied defense." 28 June 1957, p. 1, col. 7.

Anon. "Schrunk found 'not guilty' by jury." Oregonian, 29 June 1957, p. $1, \operatorname{col} .3$.

Anon. "Court drops indictments." Oregonian, $10 \mathrm{July} \mathrm{1957,} \mathrm{p.} \mathrm{1,} \mathrm{col.} 5$.

Sullivan, Ann. "Elkins ruled conspirator." Oregonian, 10 July 1957, p. 1 , col. 1 .

Anon. "Ousted D.A. files appeal." Oregonian, $10 \mathrm{July} \mathrm{1957,} \mathrm{p.} \mathrm{9,} \mathrm{col.}$ 2.

Miller, James Burr. "Writer, Patrolman find police bribery evidence." Oregonian, 5 August 1956, p. 24, col. 1.

Anon. "Indictments at a glance." Oregonian, 5 August 1956, p. 24, col. 1 .

Anon. "Three Langley cases killed." Oregonian, 6 August 1957, p. 7, col. 2.

Anon. "Time given on appeal." Oregonian, 6 August 1957, p. 11, col. 7.

Anon. "Board approves vice probe bills." Oregonian, 16 August 1957, p. $4, \operatorname{col} .6$.

Anon. "Court erases two charges." Oregonian, 21 August 1957, p. 1, col. 5.

Anon. "Five cleared." Oregonian, 31 August 1957, p. 1, col. 4.

Anon. "Stella Green turns mum." Oregonian, 5 September 1957, p. 15, col. 2 . 
Turner, Wallace and William Lambert. "State says 37 cases now live - 50 pending." Oregonian, 25 September 1957, p. 1, col. 3.

Anon. "Sorry record of the Oregon Journal." Oregonian, 25 September 1957, p. 14, col. 3.

Anon. "Elkins says paper lies." Oregonian, 26 September 1957, p. 19, col. 5 .

Anon. "Judge Redding dismisses charge." Oregonian, 28 September 1957, p. 11, col. 2 .

Sullivan, Ann. "Jim Elkins takes Fifth." Oregonian, 1 October 1957, p. 1 , col. 1 .

Anon. "Elkins quash sought." Oregonian, 21 November 1957, p. 9, col. 5.

Anon. "Oregonian reporter calls Thornton's work pitiful." Oregonian, 18 December 1957, p. 11, col. 2 .

Anon. "Thornton cites benefits of vice prosecution." Oregonian, 15 January 1958, p. 9, col. 1 .

Anon. "Traffic court traps Elkins." Oregonian, 26 January 1958, p. 1, col. 5 .

Anon. "Court drops wiretap Elkins, Clark charges." Oregonian, 15 March 1958, p. 1, col. 6 .

Anon. "Elkins case before court." Oregonian, 20 March 1958, p. 17, col. 2.

Anon. "Court affirms Langley ouster." Oregonian, 20 March 1958, p. 1, col. 7 .

Anon. "No office for Langley." Oregonian, 20 March 1958, p. 1, col. 1.

Anon. "Langley sues Oregonian for $\$ 200,000 . "$ Oregonian, 25 March 1958, p. 1 , col. 4 .

Anon. "Teamsters' link with vice affirmed." Oregonian, 26 March 1958, p. 1, col. 7; full text p. 12-15.

Turner, Wallace, and William Lambert. "Money loaned by Elkins loses Federal agent job." Oregonian, 5 April 1958, p. 1, col. 4.

Anon. "Way open for dismissal of counts against Elkins." Oregonian, 22 April 1958, p. 1, col. 7.

Anon. "Testimony sought by Thornton." Oregonian, 24 April 1958, p. 7, col. 3 . 
Anon. "Court drops indictment." Oregonian, 26 August 1958, p. 1, col. 3.

Anon. "Probe aimed at Elkins." Oregonian, 30 September 1958, p. 1, col. 5.

Anon. "Elkins, Clark face charges." Oregonian, 2 October 1958, p. 1, col. 6 .

Anon. "Ethics and Justice." Oregonian, 7 October 1958, p. 14, col. 1.

Anon. "Elkins sues ex-employee." Oregonian, 14 October 1958, Sec. 3, p. 7, col. 3 .

Anon. "Board okays vice bills." Oregonian, 16 October 1958, Sec. 3, p. 8, col. 1 .

Sullivan, Ann. "Long delayed tape recordings played." Oregonian, 17 October 1958, p. 1, col. 1 .

Anon. "Accused recall plea of guilty." Oregonian, 17 October 1958, p. 1 , col. 2 .

Sullivan, Ann. "Ex-mayor, ex-police chief testify Maloney sought vice throne." Oregonian, 18 October 1958, p. 1, col. 7.

Anon. "Professional confidence used." Oregonian, 24 October 1958, p. $27, \operatorname{col} .2$.

Anon. "Crosby passes up grand jury show." Oregonian, 29 October 1958, p. 1, col. 1 .

Lambert, William. "Vice probe successful." Oregonian, 1 November 1958, p. 1, col. 1 .

Anon. "Vice prober doubts effect." Oregonian, 3 November 1958, p. 1, col. 1 .

Anon. "Dismissal seen for 2 more vice cases." Oregonian, 17 December 1958, p. 16, col. 3.

David, Ken. "Thornton defends vice probe." Oregonian, 17 December, 1958, p. 1, col. I; additional details, p. 11 .

Anon. "Elkins, Clark penalties upheld." Oregonian 28 April 1959, p. 1, col. 6 .

Anon. "Crime expose to date - Langley, Elkins, Clark violators." Oregonian, 30 April 1959, p. 18, col. 1.

Anon. "Court defers Elkins trial." Oregonian, 23 May 1959, Sec. 2, p. 18, col. 1 . 
Anon. "Suit dropped by Langley." Oregonian, 27 May 1959, p. 1, col. 7.

Anon. "High court kills count against Elkins." Oregonian, 28 May 1959, p. 1 , col. 7 .

Anon. "Elkins, Clark lose appeal." Oregonian, 30 August 1959, p. 7, col. 5 .

Anon. "Grand jury indicts 'Mark' Nat Zusman." Oregonian, 26 September 1959 , p. 4, col. 1 .

Anon. "Oppenheimer to preside at Elkins' trial." Oregonian, 17 October 1959 , p. 15, col. 3 .

Sullivan, Ann. "Elkins defense loses motion." Oregonian, 20 October 1959 , p. 9, col. 1 .

Sullivan, Ann. "Elkins' acquittal rests with judge." Oregonian, 5 November 1959, p. 1, col. 2 .

Sullivan, Ann. "Judge frees Elkins." Oregonian, 6 November 1959, p. 1, col. 8 .

Anon. "Aftermath of probe." Oregonian, 9 November 1959, p. 16, col. 1.

Anon. "High court dismisses case against Langley." Oregonian, 29 March 1962 , p. 1, col. 3 .

Anon. "Elkins convicted of narcotics possession." Oregonian, 12 February 1965, p. 16, col. 5.

OREGON STATE ARCHIVES (O.S.A.)

Anon. History of Pinball Legislation, City of Portland, n.d., Salem, Oregon: 0.S.A. accession number 69A-68.

Anon. Letter to Clyde Crosby containing history of vice in Portland, 13 December 1956. Salem, Oregon: 0.S.A. accession number 69A-68.

Anon. Records of the Attorney General. Multnomah County Vice Investigation, 1956-1959. Salem, Oregon: 0.S.A. accession number 61-67.

Bennett, Clifford 0., Frank Daniels and Floyd Johnson. Records of the Attorney General. Salem, Oregon: 0.S.A. accession number 61-67.

Bennett, Clifford 0., Wallace Turner, Bill Lambert, Jim Elkins and Ray Clark. Records of the Attorney General. Salem, Oregon: 0.S.A. accession number 61-67. 
Anon. Records of the Justice Department. Oregon Liquor Control Commission Investigation, 1953-1955. Salem, Oregon: O.S.A. accession number $69 \mathrm{~A}-77$.

Anon. "Summary of Vice Probe." Catalogued with Robert Y. Thornton transcripts, n.d. Salem, Oregon: 0.S.A. accession number 61A-68.

Anon. "The Syndicate." Catalogued with Robert Y. Thornton transcripts, n.d. Salem, Oregon: 0.S.A. accession number 61A-68.

Anon. Untitled History of Vice in Portland, November 1956. Salem, Oregon: 0.S.A. accession number 69A-81.

Anon. Vice Investigation Data, including sound recordings and transcripts, n.d. Salem, Oregon: 0.S.A. accession number 69A-542.

Maloney, Thomas. Letter to Jim Elkins, 6 October 1954. Salem, Oregon: 0.S.A. accession number $69 \mathrm{~A}-68$.

Thornton, Robert Y. Transcript of Vice Probe Findings, 4 June 1959. Salem, Oregon: 0.S.A. accession number 61A-68.

Williams, Brad. Oregon Journal's Analysis of the Vice Situation in Portland, n.d. Salem, Oregon: 0.S.A. accession number 69A-81.

LIST OF PUBLIC FIGURES

INTERVIEWED FOR THIS STUDY

Doug Baker, (Oregon Journal reporter and columnist

Richard Carney, (attorney for Clyde Crosby)

Arthur Kaplan, (Former assistant in Oregon Attorney General's office)

Raymond Kell, (lawyer, Portland civic leader)

William Lambert, (former Oregonian, reporter)

William Langley, (former Multnomah County District Attorney)

Dorothy McCullough Lee, (former mayor of Portland, 1949-1952)

Howard Morgan, (former Democratic Party Chairman and Public Utility Commissioner for Oregon

Fred Peterson (former mayor of Portland, 1953-1956)

Captain Norm Reiter, (Portland Police Department) 
Robert Y. Thornton, (former Oregon Attorney General)

All other interviews were conducted with persons not generally known to the public, and they therefore remain anonymous. 